The Free Internet Journal

for Organic Chemistry
Review

Arkivoc 2017, part i, 356-401

\title{
Diazatriphenylenes and their thiophene analogues: synthesis and applications
}

\author{
Egor V. Verbitskiy, ${ }^{a, b, *}$ Gennady L. Rusinov, $^{a, b}$ and Valery N. Charushin $^{a, b}$ \\ ${ }^{a}$ Postovsky Institute of Organic Synthesis, Ural Branch of the Russian Academy of Sciences, \\ S. Kovalevskoy St. 22, Ekaterinburg 620 990, Russia \\ ${ }^{b}$ Ural Federal University, Mira St. 19, Ekaterinburg 620 002, Russia \\ Email: Verbitsky@ios.uran.ru
}

Received 05-27-2017

Accepted 06-23-2017

Published on line 10-03-2017

\section{Abstract}

This review highlights the recent advances in the field of the synthesis of diazatriphenylenes and their structural analogues, such as phenanthrenes, fused with the thiophene ring, and naphthalenes, condensed with two thiophene rings. Also applications of these compounds are considered.<smiles></smiles><smiles>Fc1cc2ccccc2c2ccbcc12</smiles>

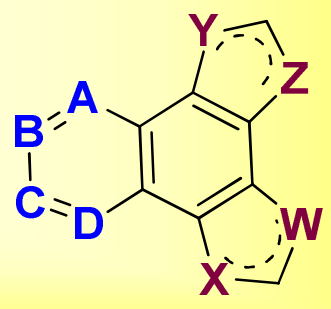

$$
\begin{array}{ll}
A=B=N, C=D=C H ; E=S, F=C H ; & W=Z=S, X=Y=C H ; \\
C=D=N, A=B=C H ; F=S, E=C H . & X=Y=S, W=Z=C H ; \\
B=C=N, A=D=C H ; & W=Y=S, X=Z=C H ; \\
A=C=N, B=D=C H ; & X=Z=S, W=Y=C H . \\
A=D=N, B=C=C H . &
\end{array}
$$

Keywords: Pyridazines; pyrimidines; pyrazines; triphenylenes; phenanthreno[9,10- $b]$ thiophene; diazanaphthalenes 


\section{Table of Contents}

1. Introduction

2. Synthesis of 1,2- and 2,3-Diazatriphenylenes and Related Thiophene-containing Systems

3. Synthesis of Tetracyclic Systems, Analogues of 1,3-Diazatriphenylenes

4. Synthesis of Heteropolycyclic Systems, Analogues of 1,4-Diazatriphenylenes

5. Conclusions

6. Acknowledgements

7. References

\section{Introduction}

Over the last two decades polycyclic aromatic hydrocarbons (PAHs) have gained a growing attention of chemists due to their unique electronic and optoelectronic properties, which can find applications in organic electronics. ${ }^{1-19}$ In this series triphenylenes ${ }^{20-37}$ and their thiophene analogues (viz. phenanthro[9,10- $\left.b\right]$ thiophenes, $^{38-42}$ naphtho[1,2- $b: 4,3-b$ ] dithiophenes, ${ }^{26,43,44}$ naphtho[2,1- $b: 3,4-b$ ] dithiophenes ${ }^{42,44,45-49}$ and naphtho[1,2-b:3,4- $b$ ] dithiophenes ${ }^{50}$ ) (Figure 1) are of particular interest, because these compounds proved to have a great potential for use in supramolecular chemistry and material science. A rapid growth of publications in this promising field, concerning both synthetic aspects and properties of PAHs is well documented in the literature. Indeed, 4843 references concerning triphenylenes are available in SciFinder database for the 1st of May, 2017).

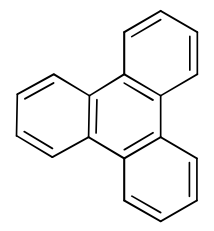

Triphenylene<smiles>c1ccc2c(c1)c1ccsc1c1ccsc21</smiles>

Phenantro[9,10-b]thiophene<smiles>c1ccc2c(c1)c1sccc1c1ccsc21</smiles><smiles>c1ccc2c(c1)c1ccsc1c1sccc21</smiles><smiles></smiles>

Naphtho[1,2-b:4,3-b']dithiophene

Naphtho[2,1-b:3,4-b]dithiophene Naphtho[1,2-b:3,4-b']dithiophene

Figure 1. Structures of triphenylene, phenanthro[9,10-b]thiophene, naphthodithiophenes.

A first-rate review on the chemistry of the above mentioned heteroaromatic systems, focusing on their synthesis, electronic properties, and applications in materials science, has recently been published. ${ }^{51}$ However, no reviews dealing with the chemistry and applications of triphenylenes, phenanthro $[9,10-b]$ thiophenes and naphthodithiophenes, bearing pyridazine (I-XVII; Section 2 of this review), pyrimidine (XVIII-XXVI; Section 3) or pyrazine rings ( $\mathbf{X X V I I - X X X I I ; ~ S e c t i o n ~ 4 ) ~ h a v e ~ s o ~ f a r ~ b e e n ~ p u b l i s h e d . ~}$ 


\section{Synthesis of 1,2- and 2,3-Diazatriphenylenes and Related Thiophene-containing Systems}

There are theoretically 17 tetracyclic diazatriphenylene structures (I-XVII), bearing two neighboring aza-groups (see Figure 2), however only dibenzo[f,h]cinnoline (I) and dibenzo[f,h]phthalazine (II) derivatives have so far been described in the literature. ${ }^{52,53}$ Both compounds are considered to be promising materials and ligands for using as dopants in organic light emitting diodes. ${ }^{52,53}$

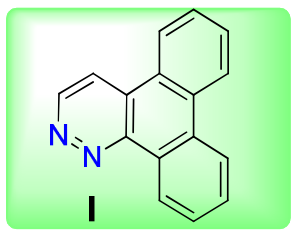

Dibenzo[f,h]cinnoline<smiles>c1ccc2c(c1)c1ccsc1c1ccnnc21</smiles>
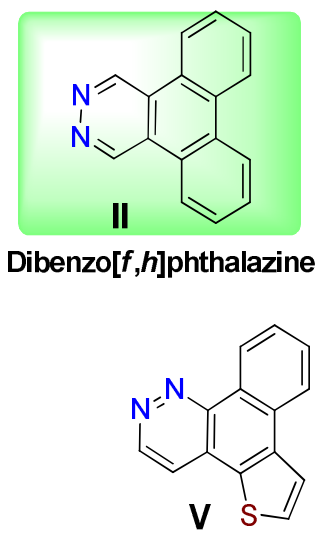

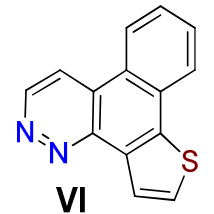

V

Benzo[f]thieno[3,2-h]cinnoline Benzo[f]thieno[3,2-h]phthalazine Benzo[h]thieno[2,3-f]cinnoline Benzo[f]thieno[2,3- $h]$ cinnoline<smiles>c1cc2c3cnncc3c3ccsc3c2cn1</smiles><smiles>c1ccc2c(c1)c1ccnnc1c1sccc21</smiles><smiles></smiles><smiles></smiles>

Benzo[f]thieno[2,3-h]phthalazine Benzo[h]thieno[3,2-f]cinnoline Dithieno[2,3-f:3',2'-h]cinnoline Dithieno[2,3-f:3',2'-h]phthalazine<smiles></smiles><smiles></smiles><smiles></smiles><smiles></smiles>

Dithieno[2,3-f: $\left.3^{\prime}, 2^{\prime}-h\right]$ cinnoline Dithieno[3,2-f:2', $\left.3^{\prime}-h\right]$ cinnoline

Dithieno[3,2-f:2',3'-h]phthalazine Dithieno[3,2-f:2',3'-h]cinnoline<smiles></smiles><smiles></smiles><smiles>c1cc2c(s1)c1ccsc1c1ccsc21</smiles>

Dithieno[3,2-f:3',2'-h]cinnoline Dithieno[2,3-f:2',3'-h]phthalazine Dithieno[2,3-f:2',3'-h]cinnoline

Figure 2. Structures of possible tetracyclic diazatriphenylenes and related thiophene-containing systems bearing the pyridazine ring.

A simple protocol for the synthesis of unsymmetrical cinnoline polycyclic systems has been developed through sulfuric acid promoted intramolecular cyclizations of 1-arylhydrazones derived from cyclohexan-1,2dione and 4-methyl cyclohexane-1,2-dione. ${ }^{54}$ In particular, 7,8,9,10-tetrahydrotribenzo[c,f,h]cinnoline (2) was prepared by cyclization of 2-[2-(phenanthren-9-yl)hydrazono]cyclohexanone (1) in $80 \% \mathrm{H}_{2} \mathrm{SO}_{4}$ at $0{ }^{\circ} \mathrm{C}(\mathrm{Scheme}$ 1). 

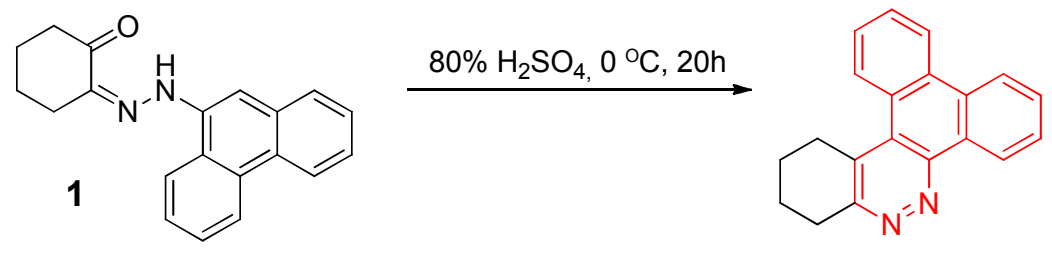

$2,60 \%$

Scheme 1. Synthesis of the dibenzo[f,h]cinnoline ring system (I) through intramolecular cyclization of cyclohexane-1,2-dione 1-arylhydrazone.

Another approach to the dibenzo[f,h]cinnoline ring system (I) was suggested by Cort et al. ${ }^{55}$ The reaction of ethyl 3a-hydroxy-2-oxo-3,3a-dihydro-2H-cyclopenta[/]phenanthrene-1-carboxylate (3) with hydrazine proceeded via rearrangement of the intermediate (4), leading to ethyl 4a-hydroxy-3-oxo-2,3,4,4a-tetrahydro$1 \mathrm{H}$-1,2-diazatriphenylen-12b-yl)acetate (5). The thermal degradation of compound (5) on melting at $\mathrm{ca} .250{ }^{\circ} \mathrm{C}$ (oil bath) resulted in the formation of dibenzo[f,h]cinnoline-3(2H)-one (6) in $20 \%$ yield (Scheme 2 ).

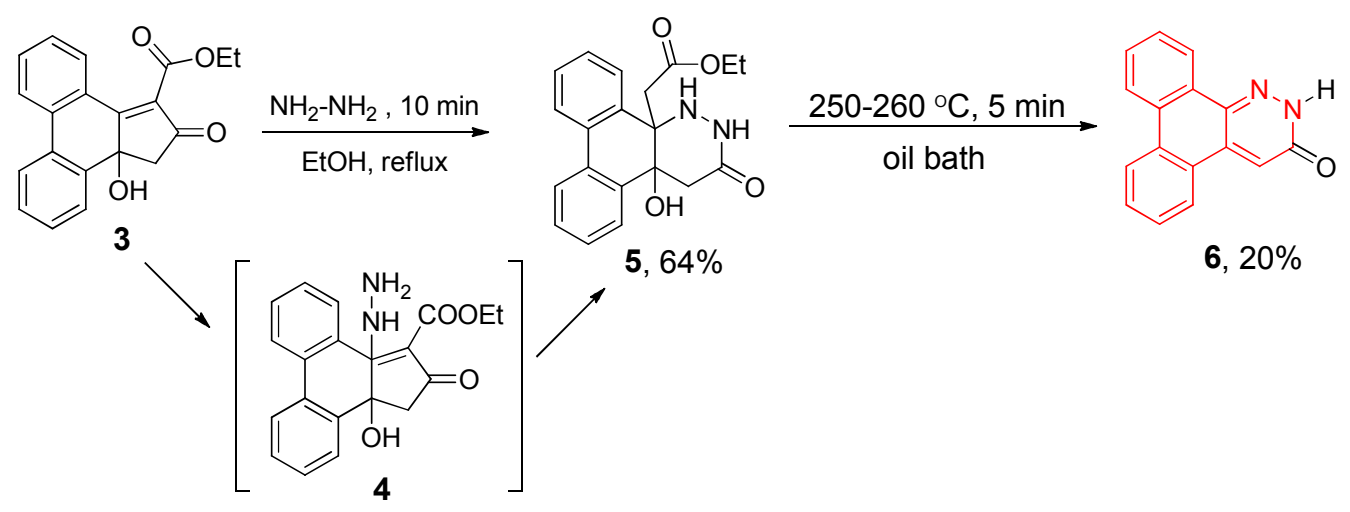

Scheme 2. Synthesis of dibenzo[f,h]cinnoline (6) from cyclopenta[/]phenanthrene (3).

A similar route to the parent dibenzo[f,h]cinnoline (I) through thermolysis of triazene (12) in $58 \%$ yield (Scheme 3) has been demonstrated by Young et al. ${ }^{56}$ The starting triazene (12) was obtained, as shown in Scheme 3. Nitration of commercially available 9-bromophenanthrene (7) afforded 8, which was subsequently reduced with iron powder in the presence of acetic acid to give bromoaniline (9). Diazotization of 9 with $\mathrm{BF}_{3} \cdot \mathrm{Et}_{2} \mathrm{O}$ and $t$-BuONO followed by quenching with $\mathrm{HNEt}_{2}$ furnished the formation of triazene (10). The Sonogashira cross-coupling reaction of $\mathbf{1 0}$ with trimethylsilylacetylene (TMSA) afforded the protected acetylene compound 11, which was then transformed into give the desired terminal acetylene 12 in $14 \%$ overall yield, taking into account all five steps (Scheme 3). 


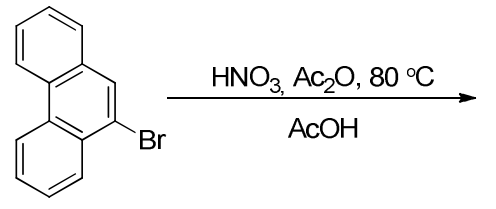

7

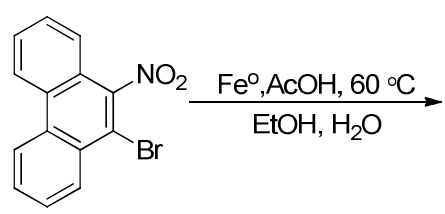

$8,42 \%$

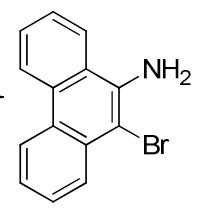

9, $84 \%$

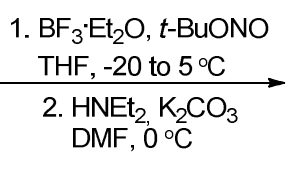

DMF, $0^{\circ} \mathrm{C}$
$\mathrm{HNEt}, \mathrm{K}_{2} \mathrm{CO}_{3}$

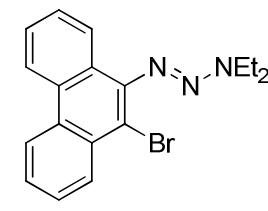

$10,59 \%$

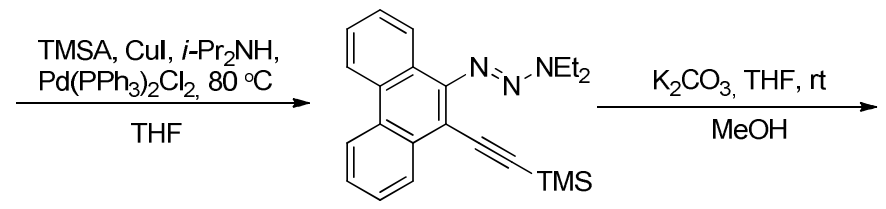

$11,75 \%$<smiles>C#Cc1c(NN=NCC)c2ccccc2c2ccccc12</smiles>

$12,90 \%$
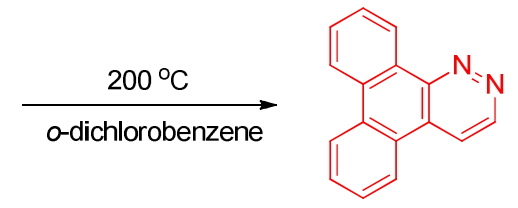

I, $58 \%$

Scheme 3. Synthesis of the parent dibenzo[f,h]cinnoline (I).

Cobalt-mediated [2+2+2] cycloisomerisation of ynedinitriles 13-15, developed by Chercheja et al, ${ }^{57}$ appears to be a novel, facile, and straight forward synthesis of dibenzo[f, $h]$ cinnolines 16-18 (Scheme 4).

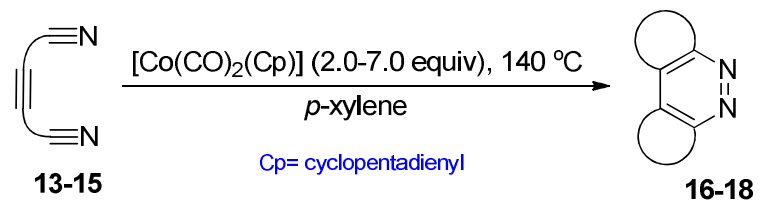

[Co(CO) 2 (Cp)] [equiv], time equiv, $18 \mathrm{~h}$

Scheme 4. Cobalt-mediated [2+2+2] cycloisomerisation of ynedinitriles 13-15 into dibenzo[f, $h]$ cinnoline derivatives 16-18. 
The formation of 2-methyldibenzo[f,h]cinnolin-3(2H)-one (21) via the palladium-catalyzed intramolecular arylation of 2-methyl-5-(2-bromophenyl)-6-phenylpyridazin-3(2H)-one (20) was investigated by Tapolcsányi et al. $^{58}$ (Scheme 5)

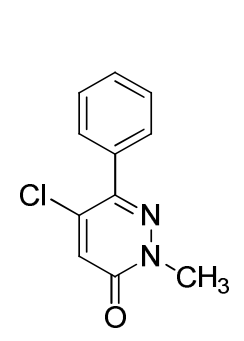

19

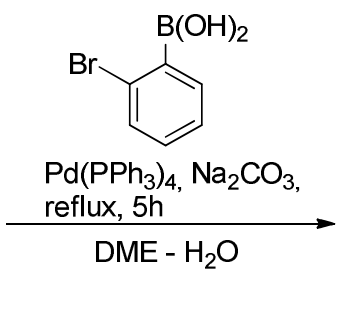

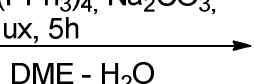

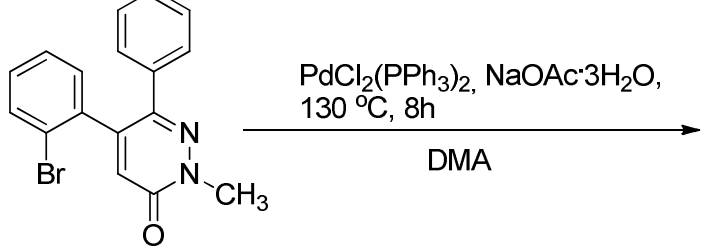

$20,62 \%$

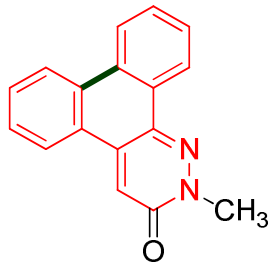

$21,46 \%$

Scheme 5. Synthesis of dibenzo[f,h]cinnolinone (21) via palladium-catalyzed intramolecular arylation.

The moderate yields of the target product $\mathbf{2 1}$ obtained for the palladium-catalyzed cyclodehydrobromination of $\mathbf{2 0}$ prompted the same group to seek alternative pathways to 1,2-diaza-analogues of triphenylene. They proposed an alternative approach to 2-methyldibenzo[f, $h]$ cinnolin-3(2H)-one (21), providing a higher yield of the latter compound via the Pschorr type ring closure reaction, caused by decomposition of the intermediate diazonium salt (24) (Scheme 6). ${ }^{58}$

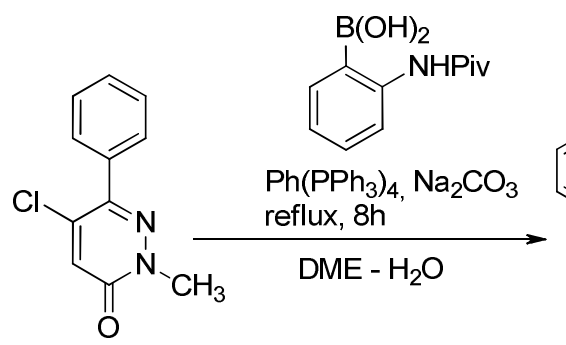

19

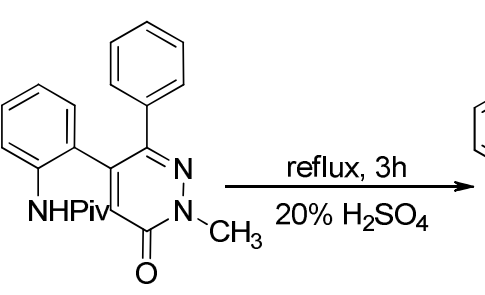

22, $95 \%$<smiles>Cn1nc(-c2ccccc2)c(-c2ccccc2N)cc1=O</smiles>

23, $65 \%$

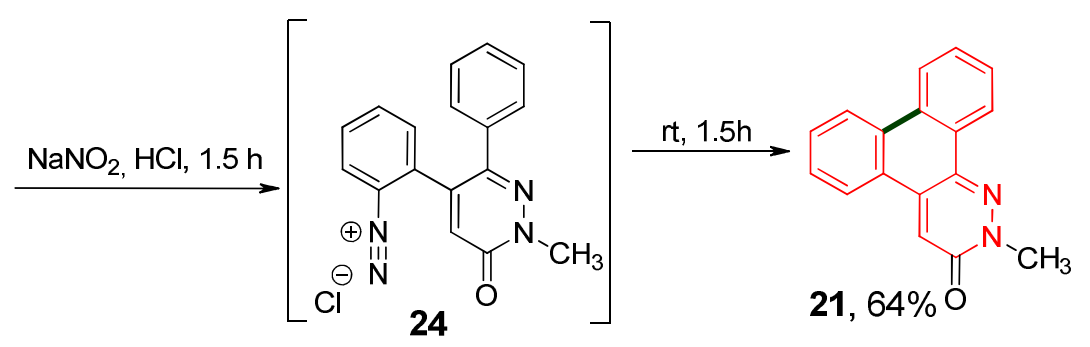

Scheme 6. Synthesis of dibenzo[f,h]cinnoline (21) via the Pschorr type ring closure reaction.

Cyclodehydrohalogenation of 2-benzyl-5-(2-bromophenyl)-4-phenylpyridazin-3(2H)-one (26) has been carried out under similar reaction conditions, as used for the synthesis of $\mathbf{2 1}$ (Scheme 7). ${ }^{58}$ In this case, only $56 \%$ of 2-benzyldibenzo[f,h]phthalazin-1(2H)-one (27) was obtained after 64 hours, while $10 \%$ of the starting material (26) was recovered. Deprotection of $\mathbf{2 7}$ with $\mathrm{AlCl}_{3}$ has been established to proceed smoothly, thus giving unsubstituted dibenzo[f,h]phthalazin-1(2H)-one (28) in good yield. 


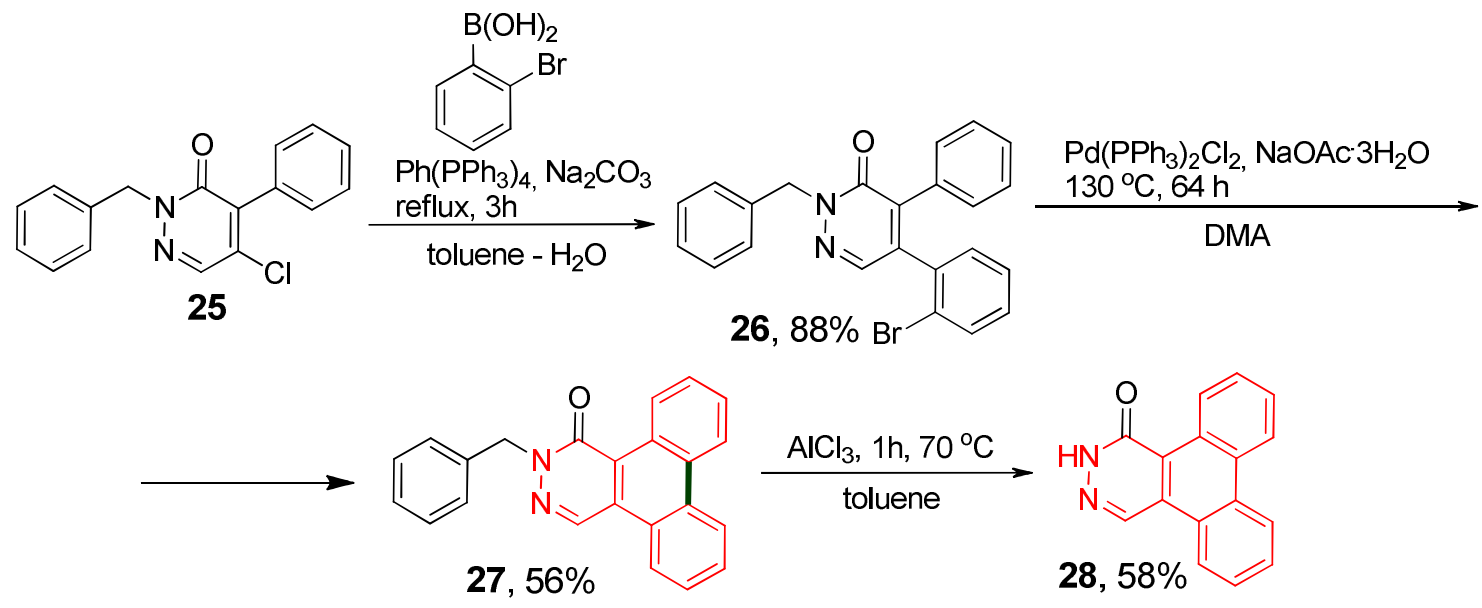

Scheme 7. Synthesis of dibenzo[f,h]phthalazine (28) (structural type II) via the palladium-catalyzed intramolecular arylation.

Analogously, 2-benzyldibenzo[f,h]phthalazin-1(2H)-one (27) was prepared from 5-(2-aminophenyl)-2benzyl-4-phenylpyridazin-3(2H)-one (30) via the Pschorr type ring closure reaction, caused by decomposition of the corresponding diazonium salt (31) at room temperature (Scheme 8).

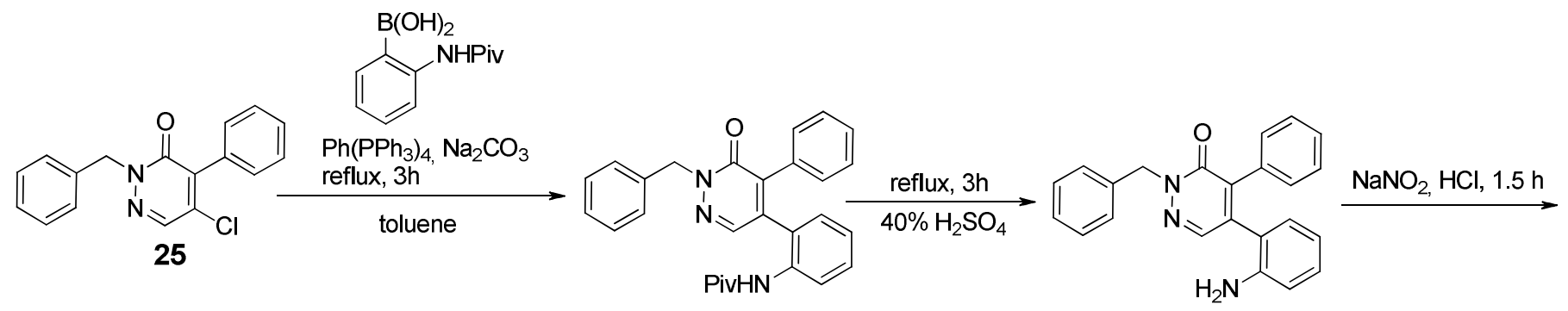

$29,89 \%$

$30,90 \%$

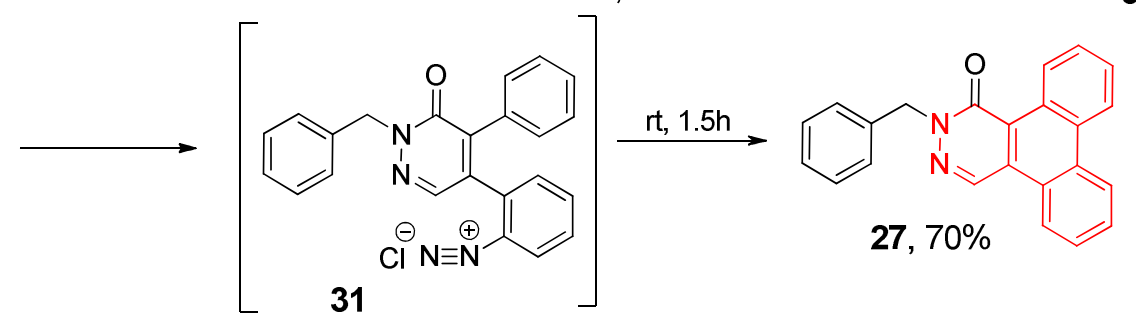

Scheme 8. Synthesis of dibenzo[f,h]phthalazine (27) (structural type II) via the Pschorr type ring closure.

In fact, the diazotization / Pschorr type ring closure of $\mathbf{3 0}$ is certainly a superior method for the preparation of 27 , affording the target product in $70 \%$ yield (56\% overall yield from 25 ) within 3 hours of the reaction time. It should be compared with $56 \%$ yield of the same product (49\% overall yield from 25 ) reached for 64 hours of the intramolecular Pd-catalyzed arylation.

The intermolecular Diels-Alder reaction is a more traditional method for the formation of dibenzo[f,h]phthalazine (II) skeleton. In particular, the reaction of perylenes (32a-c) with an excess of 2,3dihydrophthalazin-1,4-dione (33) in $\mathrm{CH}_{2} \mathrm{Cl}_{2}$ in the presence of lead (IV) acetate (taken in an amount which is equimolecular to 33 ) at $0-25{ }^{\circ} \mathrm{C}$ affords benzo[4,10]anthra[1,9,8-cdef]cinnolines 35 a-c in $11-67 \%$ yields (Scheme 9). ${ }^{59}$ 
<smiles></smiles>

32a-c<smiles></smiles><smiles></smiles>

35a, $11 \%$

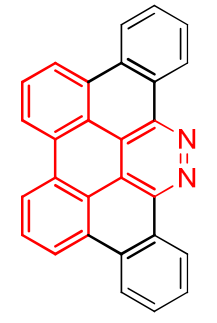

35b, $67 \%$

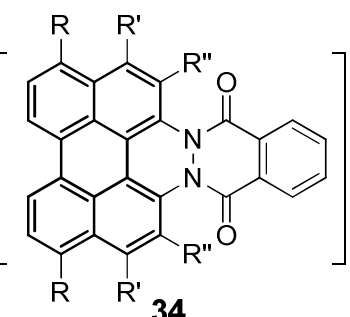

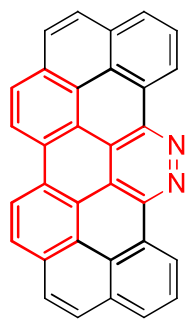

35c, $58 \%$

Scheme 9. Synthesis of dibenzo[f, $h]$ phthalazines 35a-c (structural type II) via the intermolecular Diels-Alder reaction.

Classic carbanion chemistry has been exploited for the preparation of dibenzo[f, $h]$ cinnoline derivatives: a base-promoted condensation of 2-cyanoacetohydrazide (37) with 9,10-phenanthrenequinone (36) has resulted in the formation of 3-oxo-2,3-dihydro-1,2-diazatriphenylene-4-carbonitrile (38) (Scheme 10). ${ }^{60} \mathrm{It}$ is noteworthy that compound $\mathbf{3 6}$ has been used as the starting material for the synthesis of a wide range of biologically active azolo-annulated dibenzo[f,h]cinnolines 39-46, exhibiting anti-inflammatory, analgesic, antimicrobial and anticancer activities (Scheme 10). ${ }^{60,61}$<smiles>c1ccc2c(c1)-c1ccccc1-2</smiles>

36

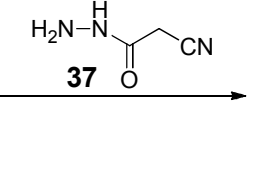

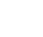

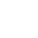

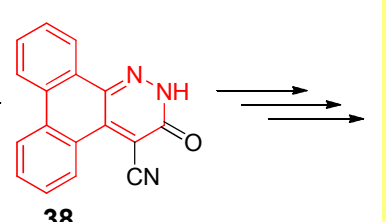

38

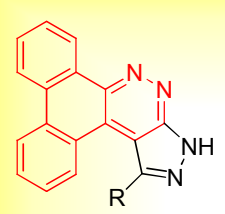

39a $\left(\mathrm{R}=-\mathrm{NH}_{2}\right)$; 39b $\left(\mathrm{R}=-\mathrm{NH}-\mathrm{NH}_{2}\right)$

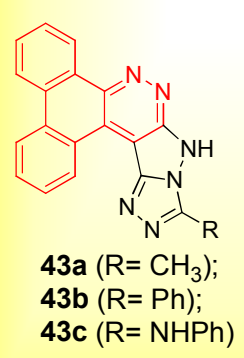

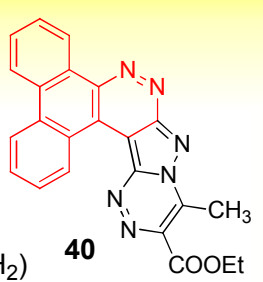
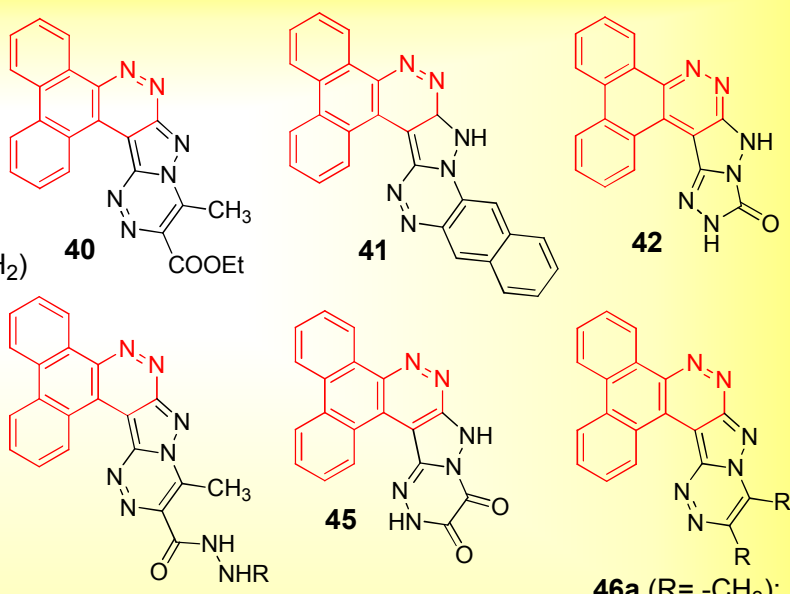

44a $\left(\mathrm{R}=-\mathrm{C}(\mathrm{O})-\mathrm{NH}_{2}\right)$;

44b $\left(\mathrm{R}=-\mathrm{C}(\mathrm{S})-\mathrm{NH}_{2}\right)$;

44c $\left(\mathrm{R}=-\mathrm{NH}-\mathrm{NH}_{2}\right)$

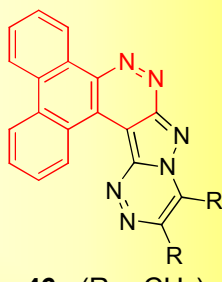

46a $\left(\mathrm{R}=-\mathrm{CH}_{3}\right)$; 46b $(\mathrm{R}=-\mathrm{Ph})$

Scheme 10. Examples of biologically active compounds in the series of dibenzo[f, $h]$ cinnolines (I).

\section{Synthesis of Tetracyclic Systems, Analogues of 1,3-Diazatriphenylenes}

There are 9 tetracyclic structures (XVIII-XXVI) bearing 1,3-diazine fragments (see Figure 3). However, only four types of derivatives, viz. dibenzo[f,h]quinazolines (XVIII), benzo[f]thieno[3,2- $h]$ quinazolines (XIX), dithieno[2,3- 
$f: 3^{\prime}, 2^{\prime}-h$ ]quinazolines (XXIII) and dithieno[3,2-f:3',2'-h]quinazolines (XXVI) have so far been described in the literature. Dibenzo[f,h]quinazolines (XVIII) have been considered as the basic structures for phosphorescent or electroluminescent host and/or hole transport materials to be used in organic electroluminescent devices. $^{53,62-82}$

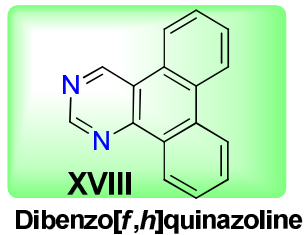

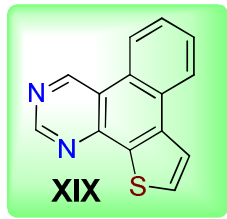

Benzo[f]thieno[3,2- $h]$ quinazoline

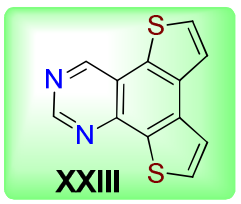

Dithieno[2,3-f:3',2'-h]quinazoline

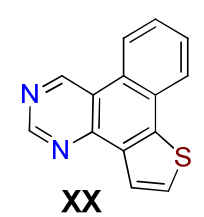

Benzo[f]thieno[2,3- $h]$ quinazoline

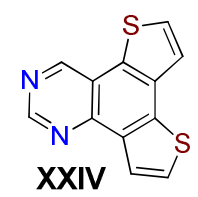

Dithieno[2,3-f:2',3'-h]quinazoline

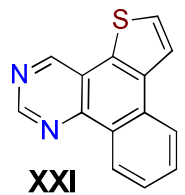

Benzo[h]thieno[2,3-f]quinazoline

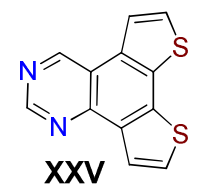

Dithieno[3,2-f:2',3'-h]quinazoline

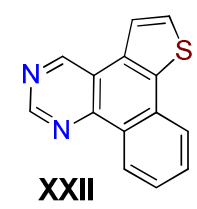

Benzo[h]thieno[3,2-f]quinazoline

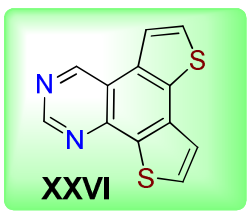

Dithieno[3,2-f:3',2'-h]quinazoline

Figure 3. Structures of possible tetracyclic systems, as analogues of 1,3-diazatriphenylene.

Although many synthetic approaches are exploited to obtain dibenzo[f,h]quinazolines (XVIII), most of the practically important syntheses can be classified into two types. The first type syntheses of XVIII are based on closure of the 1,3-diazine ring, while the second type of the syntheses of XVIII involves construction of the triphenylene framework on the basis of the 1,3-diazine scaffold.

Various cyclocondensations are related with the first type of the synthesis of dibenzo[f,h]quinazolines (XVIII). Thus, Mahmoodi et al. ${ }^{83}$ have demonstrated a simple cyclocondensation of phenanthren-9,10-dione (47) with urea (48), proceeding in an alkaline ethanol solution, and affording dibenzo[f, $h]$ quinazolin$2,4(1 H, 3 H)$-dione $(49)$ in good yield (Scheme 11$)$.

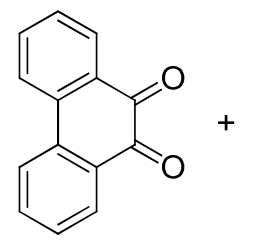

47<smiles>NC(N)=O</smiles>

48<smiles>CCOC(=O)c1ccccc1</smiles>

$\mathrm{EtOH}-\mathrm{H}_{2} \mathrm{O}$

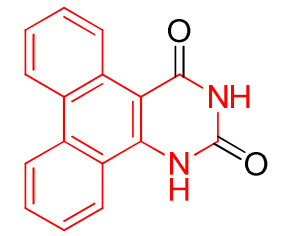

$49,57 \%$

Scheme 11. Synthesis of dibenzo[f,h]quinazolin-2,4(1H,3H)-dione (49) through the cyclocondensation of phenanthren-9,10-dione (47) with urea (48).

Another two-step pathway to dibenzo[f,h]quinazoline (XVIII) skeleton has been proposed by Hara et al ${ }^{78}$ At the fist step, 9-iodophenanthrene (50) reacts with 3-chlorobenzamidine hydrochloride (51) at $100-110{ }^{\circ} \mathrm{C}$ in dimethylformamide in the presence of $\mathrm{Cul}, \mathrm{Cs}_{2} \mathrm{CO}_{3}$ and $N, N$-dimethylethylenediamine to afford $N$ - 
(phenanthren-9-yl)-3-chlorobenzamidine (52). At the final step, the compound $\mathbf{5 2}$ reacts with an excess of diethyl acetal (53) in DMF at $120^{\circ} \mathrm{C}$ for 1 hour to give 2-(3-chlorophenyl)dibenzo[f,h]quinazoline (54) in 39\% overall yield (Scheme 12).

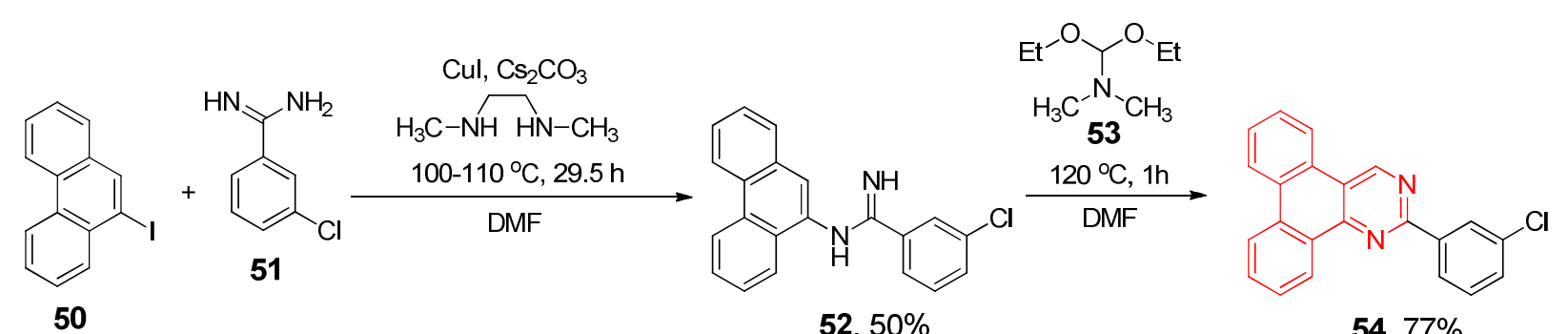

Scheme 12. Synthesis of dibenzo[f,h]quinazoline (XVIII) skeleton via condensation of $N$-(phenanthren-9-yl)-3chlorobenzamidine (52) with diethyl acetal (53).

The second principal pathway to obtain dibenzo[f,h]quinazolines (XVIII) involves the assembly of polyaromatic framework on the basis of the pyrimidine scaffold, and this approach is well-documented in literature. In particular, Olivera et al. ${ }^{84,85}$ have demonstrated a straightforward synthetic approach to 6,7,10,11-tetrasubstituted dibenzo[f,h]quinazolines (56) via the intramolecular Stille-Kelly stannylation / coupling of $0, o^{\prime}$-dihalogenated 4,5-diarylpyrimidines (55) (Scheme 13).
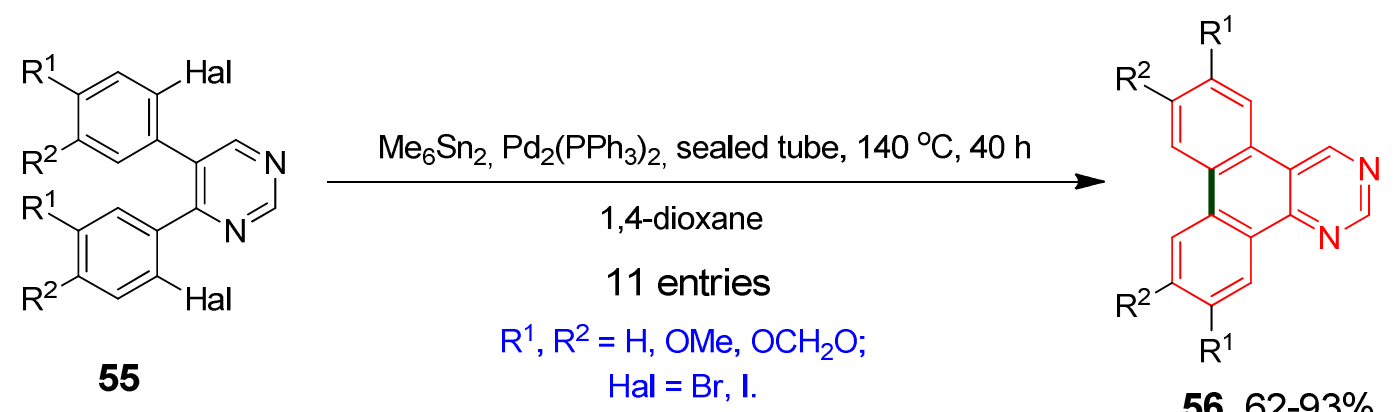

$56,62-93 \%$

Scheme 13. Synthesis of dibenzo[f,h]quinazolines (56) via the intramolecular Stille-Kelly stannylation / coupling of $0, o^{\prime}$-dihalogenated 4,5-diarylpyrimidines.

2,4,5,8-Tetramethoxydibenzo[f,h]quinazoline (58) has been prepared in $68 \%$ yield through the intramolecular $\mathrm{C}-\mathrm{H}$ arylation of the corresponding chloride $\mathbf{5 7}$ in the presence of palladium(II) acetate and tri(cyclohexyl)phosphine, as an effective transition-metal catalyst, and cesium carbonate, as a base (Scheme $14)^{86}$ 


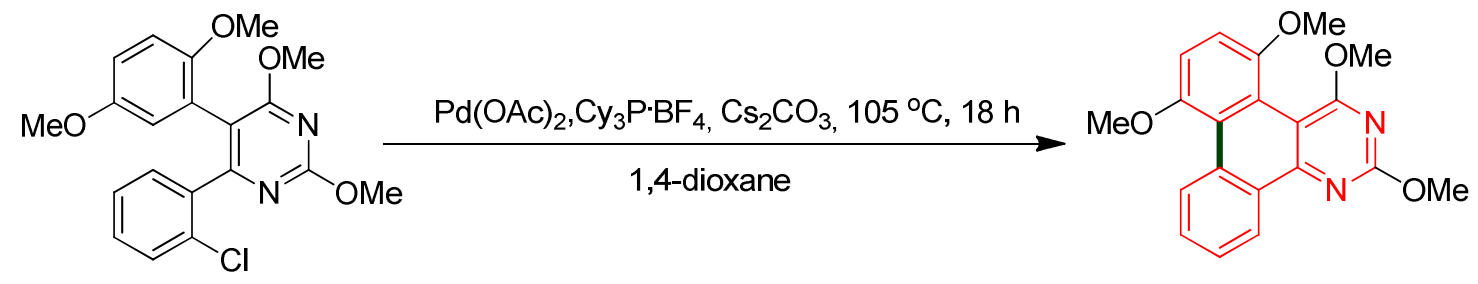

57

$58,68 \%$

Scheme 14. Synthesis of the dibenzo[f,h]quinazoline (XVIII) skeleton via the Pd-catalyzed intramolecular $\mathrm{C}-\mathrm{H}$ arylation of 0 -chloro substituted 4,5-diphenylpyrimidine (57).

Intramolecular version of nucleophilic aromatic substitution of hydrogen (the $\mathrm{S}_{\mathrm{N}}{ }^{\mathrm{H}}$ reaction) has been used to synthesize dibenzo[f,h]quinazoline derivative (60) from 5-([1,1'-biphenyl]-2-yl) substituted pyrimidine (59), by using concentrated sulfuric acid as a catalyst and iron(III) chloride, as an oxidant (Scheme 15). ${ }^{79}$ For a better understanding of the $S_{N}{ }^{H}$ reactions, see the recently published review ${ }^{87}$ and references cited therein.<smiles>Cc1ncncc1-c1ccccc1-c1ccccc1</smiles>

59

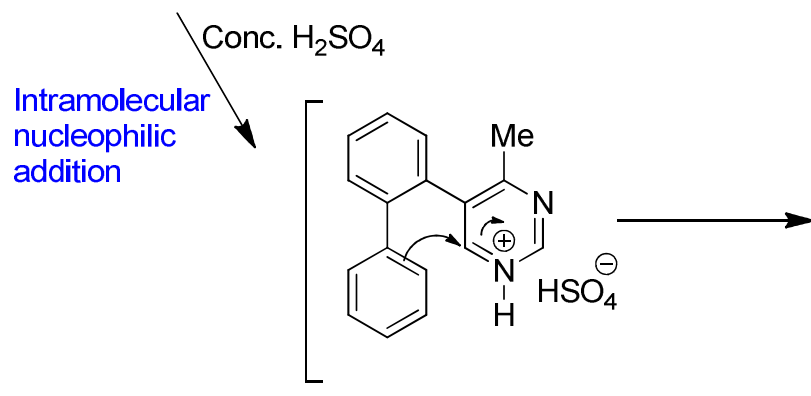

Conc. $\mathrm{H}_{2} \mathrm{SO}_{4}, \mathrm{FeCl}_{3}$, rt, $20 \mathrm{~h}$

$\mathrm{CH}_{2} \mathrm{Cl}_{2}$

$\mathrm{S}_{\mathrm{N}}{ }^{\mathrm{H}}$-reaction

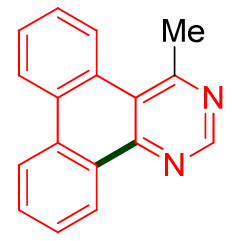

$60,54 \%$

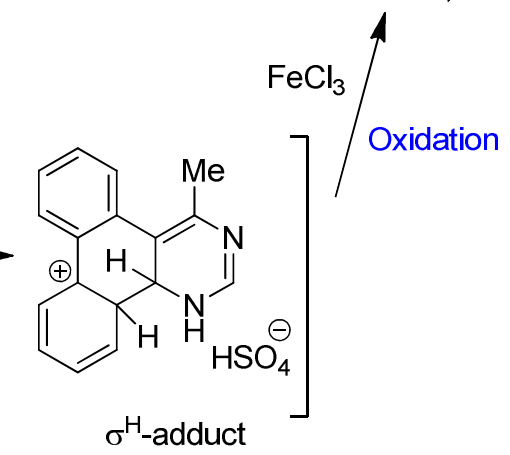

Scheme 15. Synthesis of dibenzo[f,h]quinazoline (XVIII) skeleton from 5-(1,1'-biphenyl-2-yl) substituted pyrimidine (59) via intramolecular $\mathrm{S}_{\mathrm{N}}{ }^{\mathrm{H}}$ reaction.

Also oxidative cyclodehydrogenation (the Scholl reaction) appears to be a versatile tool for the construction of 1,3-diaza-analogues of triphenylenes. It requires a Lewis acid and oxidant, and is supposed to proceed through either the radical-cation (electron transfer) or arenium cation (proton transfer) intermediates. ${ }^{88,89} \mathrm{~A}$ variety of oxidants, including $\mathrm{Fe}(\mathrm{III}), \mathrm{I}(\mathrm{III}), \mathrm{TI}$ (III), Ru(IV) and V(V), and their effects on the oxidative cyclodehydrogenation reaction, have been elucidated. ${ }^{85}$ In particular, Olivera et al. ${ }^{85,90}$ have observed that phenyliodine(III) bis(trifluoroacetate) (PIFA) is the most suitable oxidant for the intramolecular reaction of non-halogenated 4,5-diarylpyrimidines (61) into the corresponding methoxy substituted dibenzo[f,h]quinazolines (62) in $23-88 \%$ yields (Scheme 16 ). 

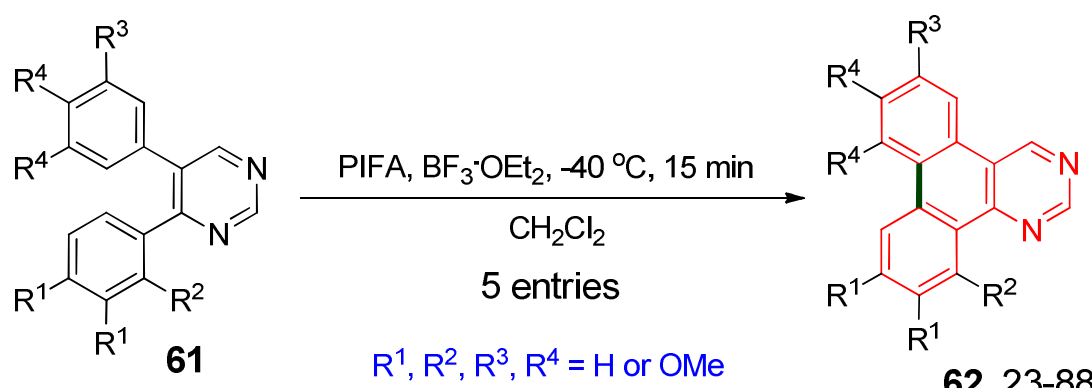

62, $23-88 \%$

Scheme 16. Synthesis of substituted dibenzo[f, $h]$ quinazolines (62) via the oxidative cyclodehydrogenation of 4,5-diphenylpyrimidines (61).

On the contrary, iron(III) chloride proved to be an appropriate oxidant for the intramolecular oxidative cyclodehydrogenation of 5-(1,1'-biphenyl-2-yl) substituted pyrimidines (63) and compounds (65 and 67), bearing a similar structural motif, to prepare 2 -substituted dibenzo[f, $h]$ quinazolines ${ }^{52}$ (64) (Scheme 17), as well as nitrogen-doped nanographenes ${ }^{91-95}(66,68$ and 69) (Schemes 18 and 19). It is remarkable that, whereas the Scholl cyclodehydrogenation of 1,2-dipyrimidyl-3,4,5,6-tetra(4-t-butylphenyl)benzene (67) by action of $\mathrm{AlCl}_{3} / \mathrm{CuCl}_{2}$ in $\mathrm{CS}_{2}$ results in the formation of heterosuperbenzene $68 \mathrm{a}$, while use of a milder catalytic system ( $\mathrm{FeCl}_{3}$ /nitromethane/dichloromethane) affords a mixture of $68 \mathrm{a}$ (35\%) and of "half-cyclized" $69 \mathrm{a}$ (32\%). ${ }^{92,94} \mathrm{It}$ has been found that neither treatment of $69 \mathrm{a}$ with $\mathrm{FeCl}_{3}$, nor use of $\mathrm{AlCl}_{3} / \mathrm{CuCl}_{2}$, results in the formation of 68a, thus indicating that the partially cyclodehydrogenated compound 69 is apparently not an intermediate in the formation of heterosuperbenzene 68 in this reaction.

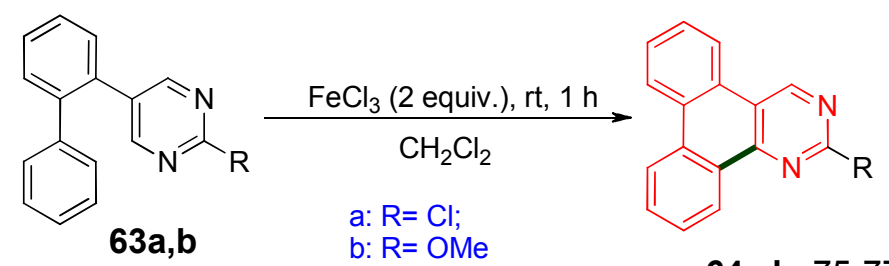

$64 a, b, 75-77 \%$

Scheme 17. Synthesis of substituted dibenzo[f,h]quinazolines $(\mathbf{6 4 a , b})$ from 5-([1,1'-biphenyl]-2-yl)-substituted pyrimidines (63) via the intramolecular oxidative cyclodehydrogenation.

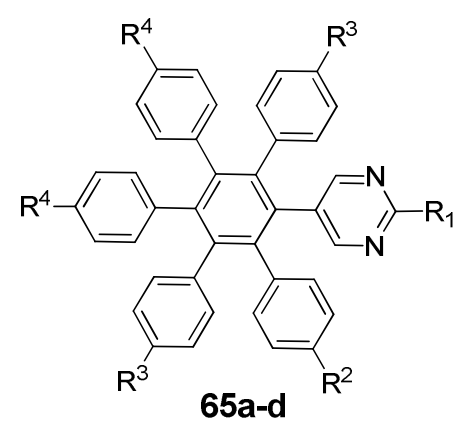

$65 a-d$
$\mathrm{FeCl}_{3}$ (30 equiv.), rt, 90 min $\mathrm{CH}_{2} \mathrm{Cl}_{2}-\mathrm{CH}_{3} \mathrm{NO}_{2}$

a: $R^{1}, R^{2}, R^{3}, R^{4}=H$

b: $\mathrm{R}^{1}, \mathrm{R}^{3}=\mathrm{H} ; \mathrm{R}^{2}, \mathrm{R}^{4}=t-\mathrm{Bu}$

c: $\mathrm{R}^{1}=\mathrm{H} ; \mathrm{R}^{2}, \mathrm{R}^{3}, \mathrm{R}^{4}=t-\mathrm{Bu}$

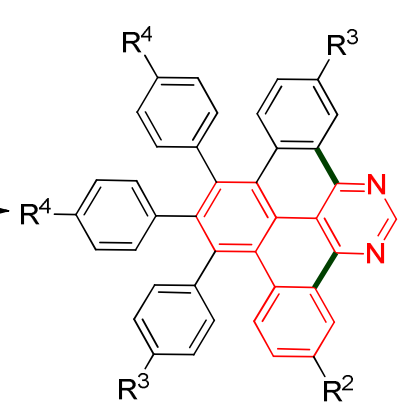

66 a, $94 \%$

$66 \mathrm{~b}, 90 \%$

$66 \mathrm{c}, 85 \%$

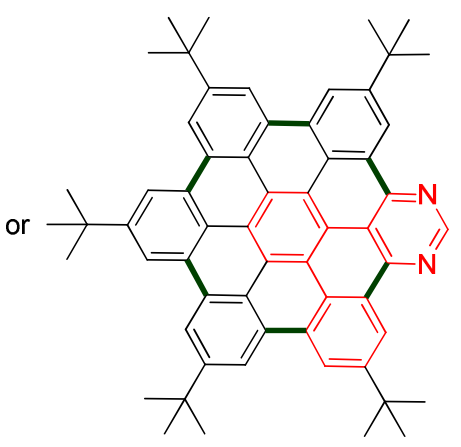

66d, $60 \%$

Scheme 18. Synthesis of heterosuperbenzenes 66 from pyrimidyl substituted pentaphenylbenzenes 65 via Scholl cyclodehydrogenation. 


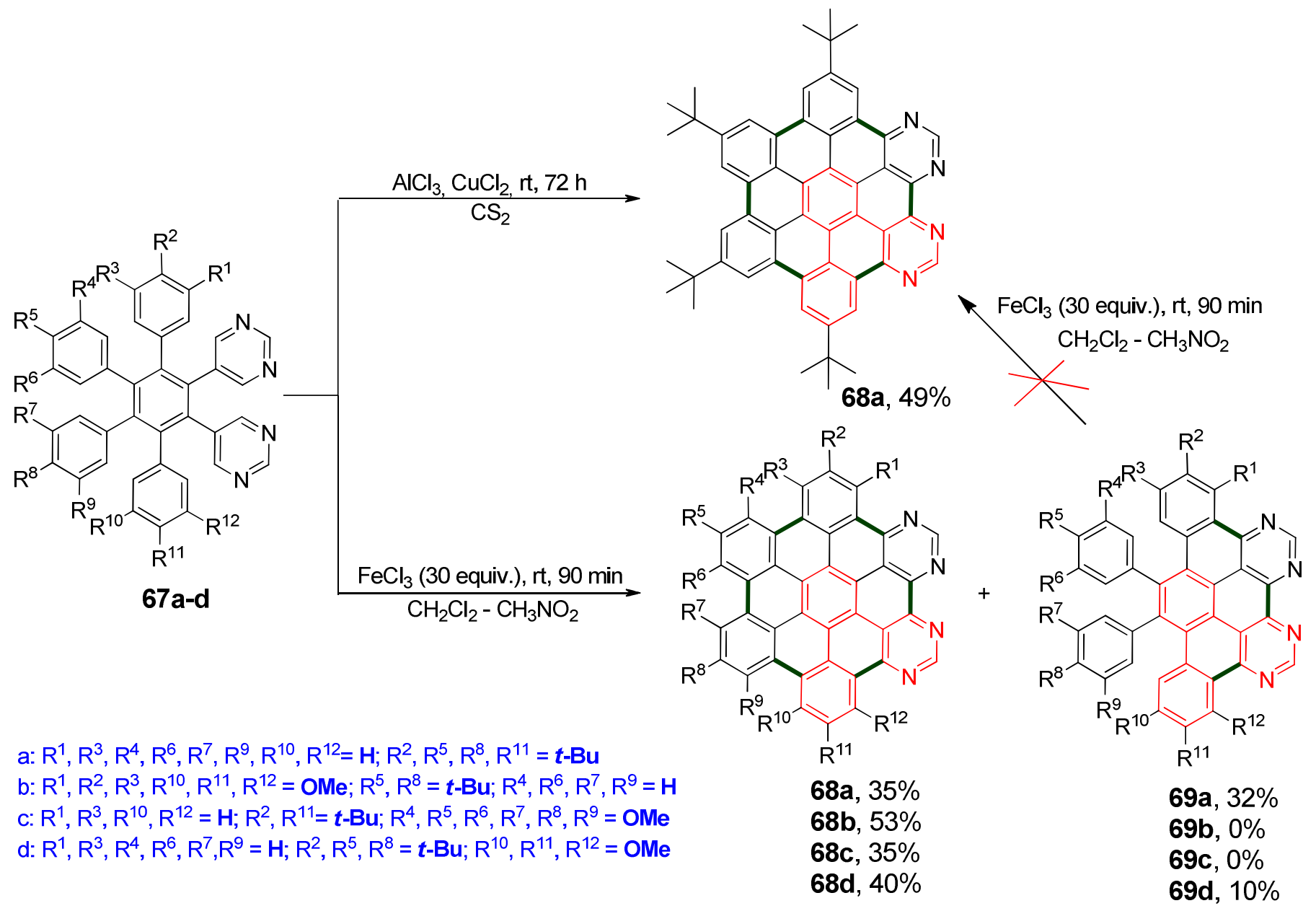

Scheme 19. Synthesis of heterosuperbenzenes (68 and 69) from 1,2-dipyrimidyl-3,4,5,6-tetraarylbenzenes 67 via Scholl cyclodehydrogenation.

Also, Draper et al. ${ }^{96}$ have demonstrated that use of elemental bromine in the reaction with diazapolyphenylenes results in the intramolecular bond formation with the pyrimidine ring, and the reaction is accompanied by bromination of the phenyl substituents to give products $66 \mathbf{a}, \mathbf{e}, \mathbf{f}$, which can be controlled by the reaction conditions (Scheme 20).

Recently, Mohamed et al. ${ }^{97}$ have proposed a novel versatile method for the synthesis of fused functionalized helicenes, affording, for instance, naphtho[2,1-f]thieno[3',2':3,4]naphtho[2,1- $h]$ quinazoline (71) in a high yield (Scheme 21). The first core ring of the helicene (E) is assembled by treatment of bis(biaryl)acetylene (A) with 1.1 equiv of $\mathrm{ICl}$ in dichloromethane at $-78{ }^{\circ} \mathrm{C}$ for 1 hour. The iodonium-induced carbocyclization affords either substituted 6-aryl-5-iodochrysene (B), or 9-iodo-10-arylphenanthrene (C), or a mixture of both. A convenience of this convergent synthetic strategy is that the subsequent photochemical cyclodehydroiodination step is supposed to convert both structural isomers (C or B) into the same final helical product (E), as shown in Scheme 22. 


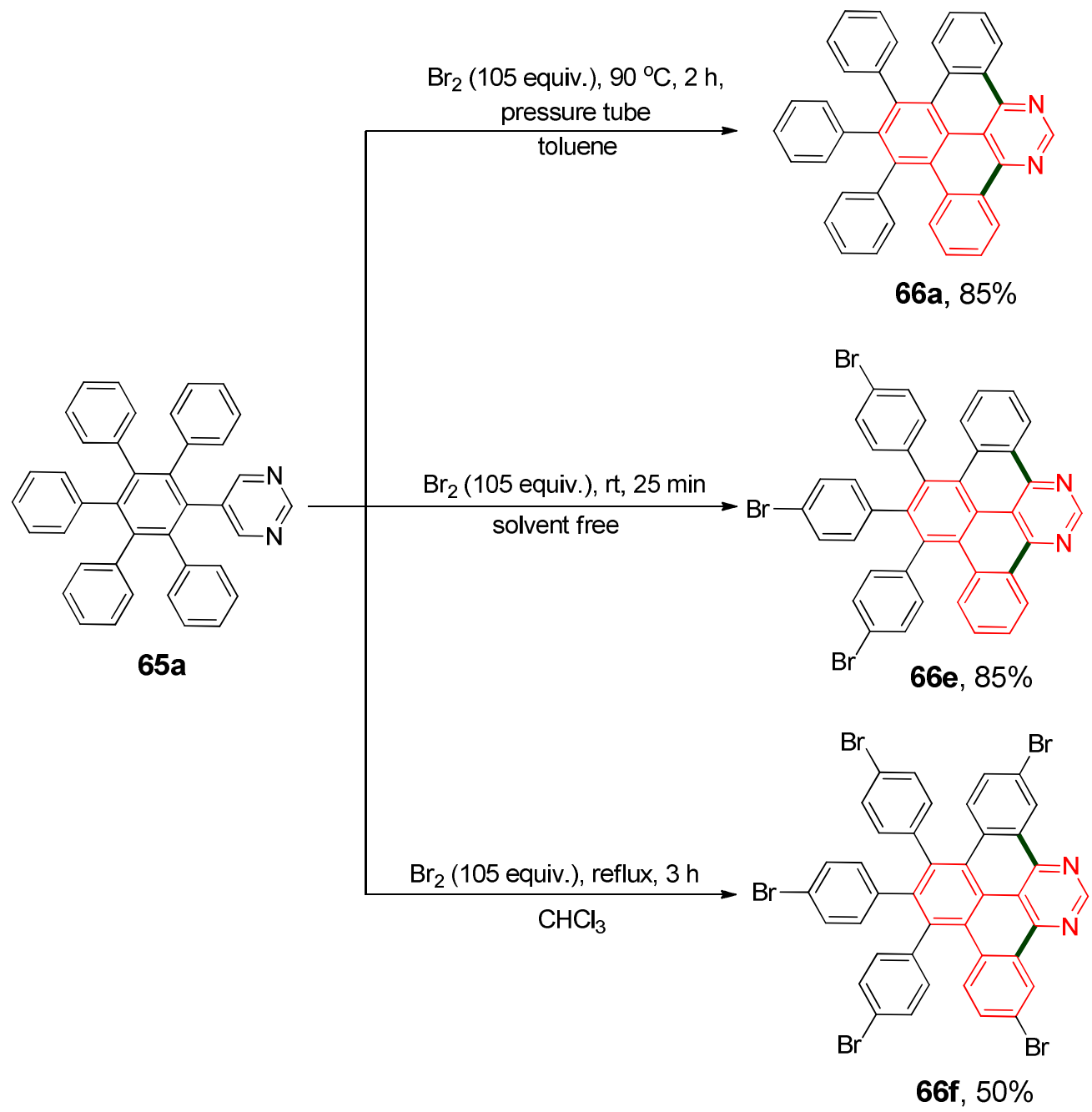

Scheme 20. Synthesis of 8,9,10-triphenyltribenzo[e,gh,j]perimidines $66 \mathbf{a}, \mathbf{e , f}$ from pyrimidyl substituted pentaphenylbenzene 65a via intramolecular oxidative cyclodehydrogenation by action of elemental bromine.<smiles>C(#Cc1c(-c2cncnc2)ccc2ccccc12)c1ccccc1-c1cccs1</smiles>

70
1. $\mathrm{ICl},-78^{\circ} \mathrm{C}, 1 \mathrm{~h}, \mathrm{CH}_{2} \mathrm{Cl}_{2}$<smiles>c1ccc2c(c1)c1ccccc1c1c3ccccc3c3ccccc3c21</smiles>

71, $90 \%$

Scheme 21. Synthesis of dibenzo[f,h]quinazoline $\mathbf{7 1}$ (structural type XVIII) through the iodonium-induced carbocyclization with the subsequent light-induced cyclodehydroiodination. 

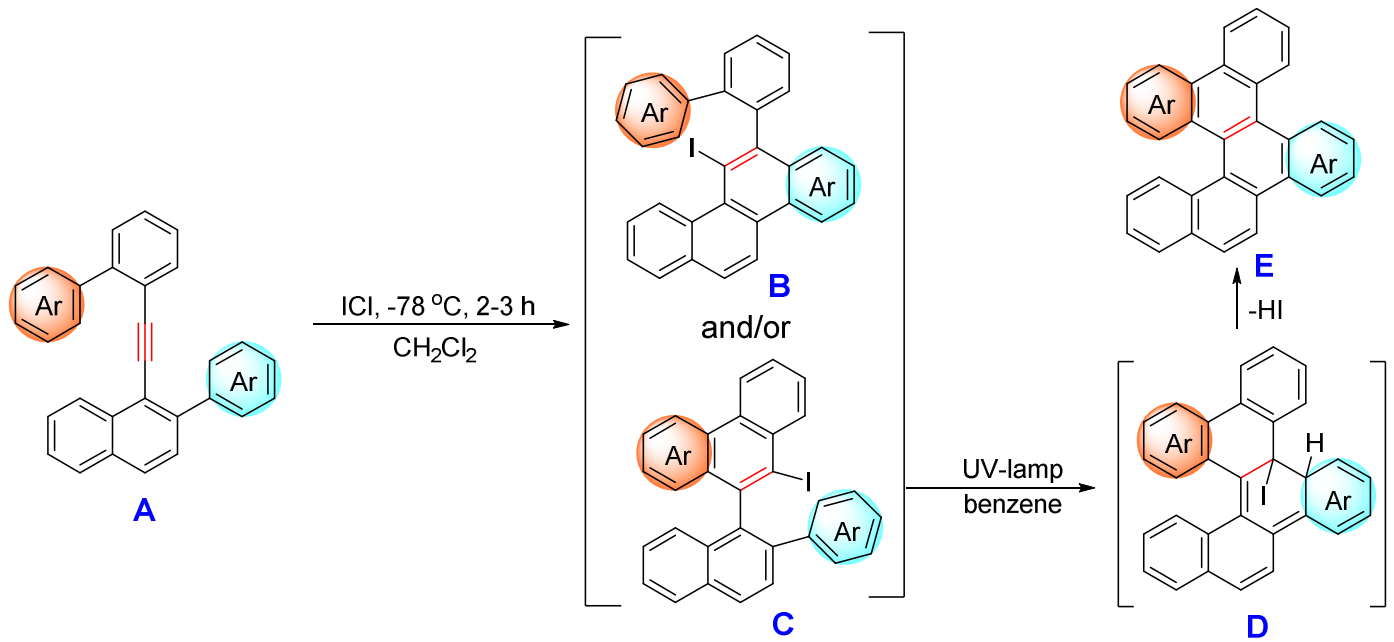

Scheme 22. A mechanism proposed for the synthesis of fused functionalized helicenes through the iodoniuminduced carbocyclization of bis(biaryl)acetylenes with subsequent light-induced cyclodehydroiodination.

Furthermore, Zhang et al. ${ }^{98}$ have described a simple and efficient method for the synthesis of benzo[h]naphtho[1,2-f]quinazolines (74) and benzo[h]phenanthren[9,10-f]quinazoines (74) from intermediate 4-(2hydroxyphenyl)-5-(naphthalen-1-yl)pyrimidines (73) and 4-(2-hydroxyphenyl)-5-(phenanthren-1-yl)pyrimidines (73) through the intramolecular photo-induced dehydration, proceeding in $\mathrm{EtOH}-\mathrm{H}_{2} \mathrm{O}(19: 1)$ solution under an argon atmosphere for $35 \mathrm{~h}$ (Scheme 23). The corresponding intermediates 73 have been obtained in 55-97\% yields by condensation of substituted 3-aryl-chromones (72) with formamidine acetate, acetamidine hydrochloride or guanidine hydrochloride in ethanol at $78{ }^{\circ} \mathrm{C}$ (Scheme 23).

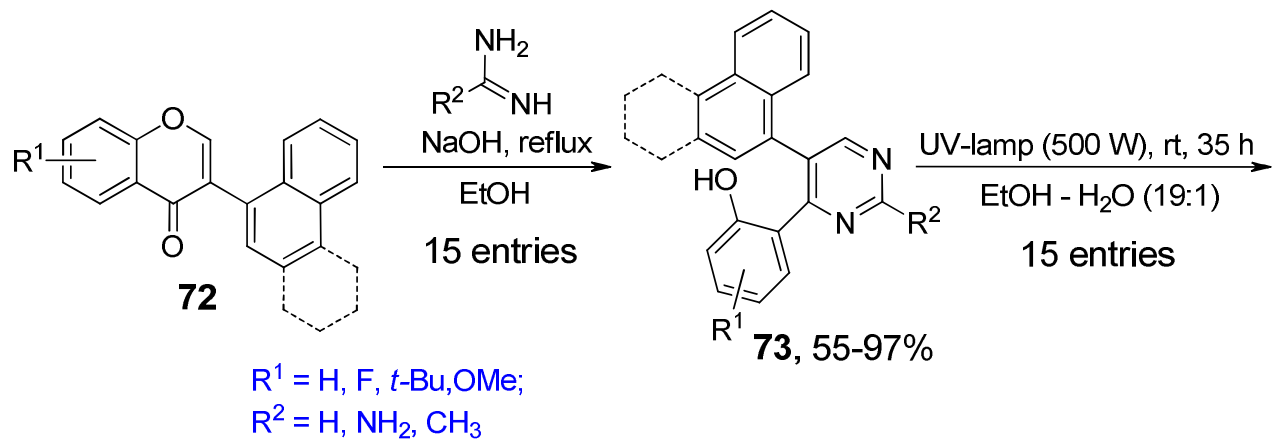

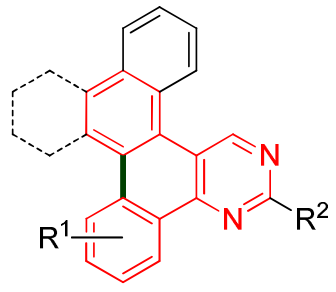

74, $30-70 \%$

Scheme 23. Synthesis of dibenzo[f,h]quinazoline (XVIII) skeleton via the photoinduced dehydration.

A reasonable mechanism for the synthesis of polycyclic benzoquinazolines $\mathbf{7 4}$ has been formulated (Scheme 24). ${ }^{98}$ Being irradiated with the UV-light, compound $\mathbf{7 2}$ in the excited state is transformed to the keto form 72A by means of the intramolecular proton transfer. The intermediate 72B is then formed under UV irradiation, followed by dehydration into the target product 74. 


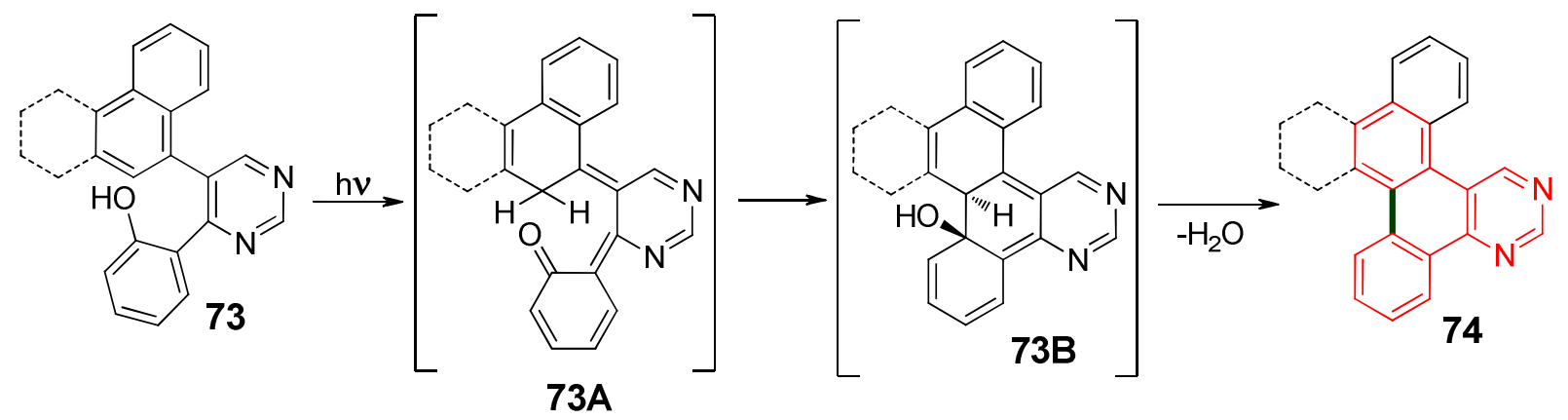

Scheme 24. A plausible mechanism for the photocyclization reaction.

The same procedure has been used for the synthesis of a wide range of dibenzo[f,h][1,2,4]triazolo[3,4-b]quinazolines (76), which are of interest as compounds exhibiting distinct fluorescent properties (Scheme 25). ${ }^{99}$
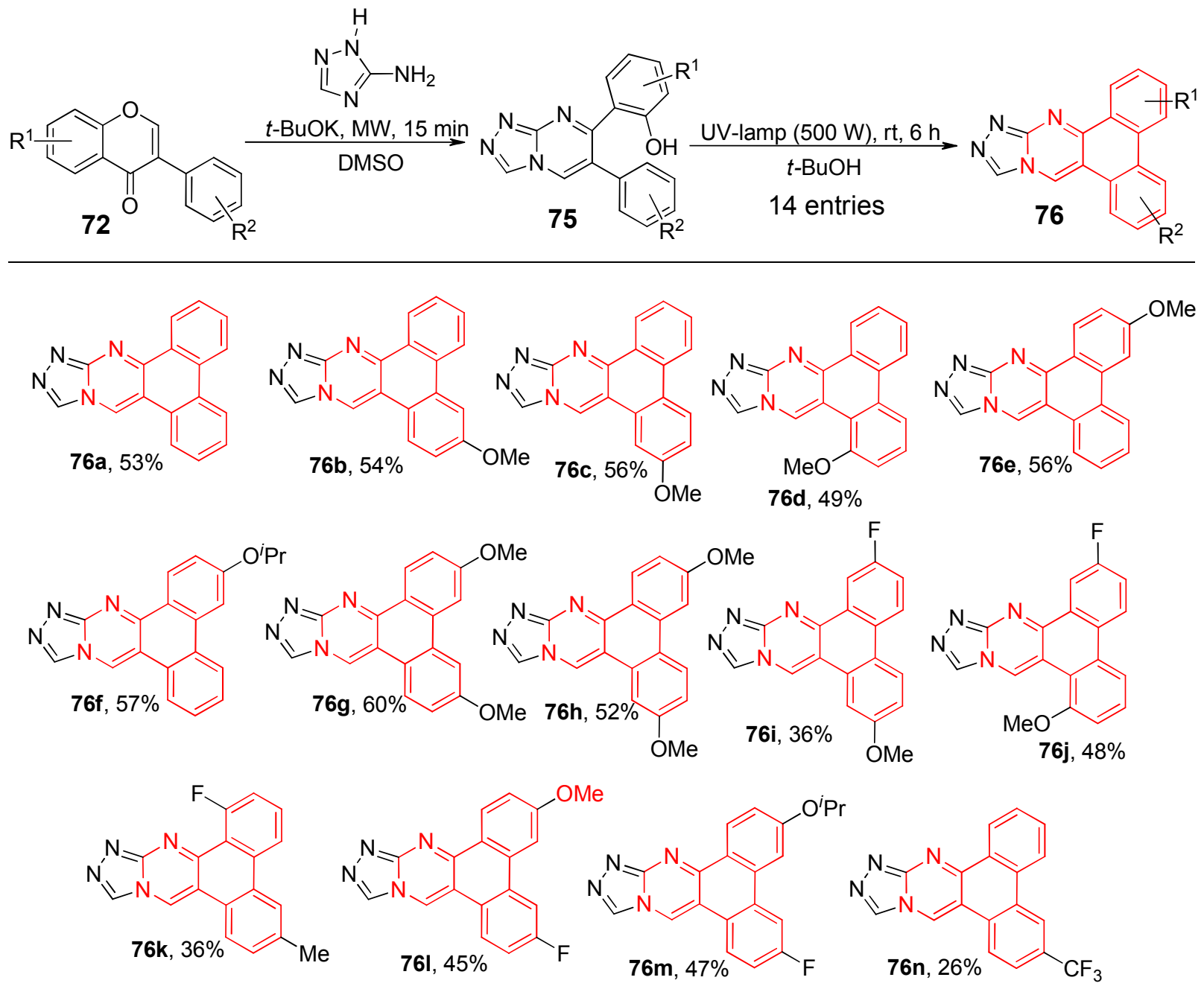

Scheme 25. Synthesis of dibenzo[f, $h][1,2,4]$ triazolo[3,4-b]quinazolines (76a-n) through a two-step reaction pathway; overall yields of product $\mathbf{7 6}$ from $\mathbf{7 2}$ are given.

Only a few papers dealing with the synthesis of benzo[f]thieno[3,2-h]quinazolines (XIX), dithieno[2,3-f:3',2'-h]quinazolines (XXIII) and dithieno[3,2-f:3',2'-h]quinazolines (XXVI) are available in the 
literature. ${ }^{100-102}$ In particular, a simple synthetic route to compounds $\mathbf{X I X}, \mathbf{X X I I I}$ and $\mathbf{X X V}$ VI has been suggested using palladium-catalyzed intramolecular cyclization of 4-(3,5-dibromothiophen-2-yl)-5-(hetero)arylpyrimidines (79a-g), proceeding in DMF at $185{ }^{\circ} \mathrm{C}$ under microwave irradiation for 10 min (Scheme 26). ${ }^{100}$ Unfortunately, the desired products $80 \mathrm{a}-\mathrm{g}$ were obtained in low yield due to a side reaction, affording 5-aryl4-(thien-2-yl)pyrimidines (81a-c) in 20-37\% yields. The starting pyrimidines (79a-g) were obtained as shown in Scheme 26. The nucleophilic displacement of hydrogen (the $\mathrm{S}_{\mathrm{N}}{ }^{\mathrm{H}}$-reaction) ${ }^{87}$ in 5 -(hetero)arylpyrimidines (77ag) by action of 2,4-dibromothiophene (78) proceeds smoothly in $\mathrm{CF}_{3} \mathrm{COOH}$, followed by oxidation of the intermediates into 4-(3,5-dibromothien-2-yl)-5-(hetero)arylpyrimidines (79a-g).

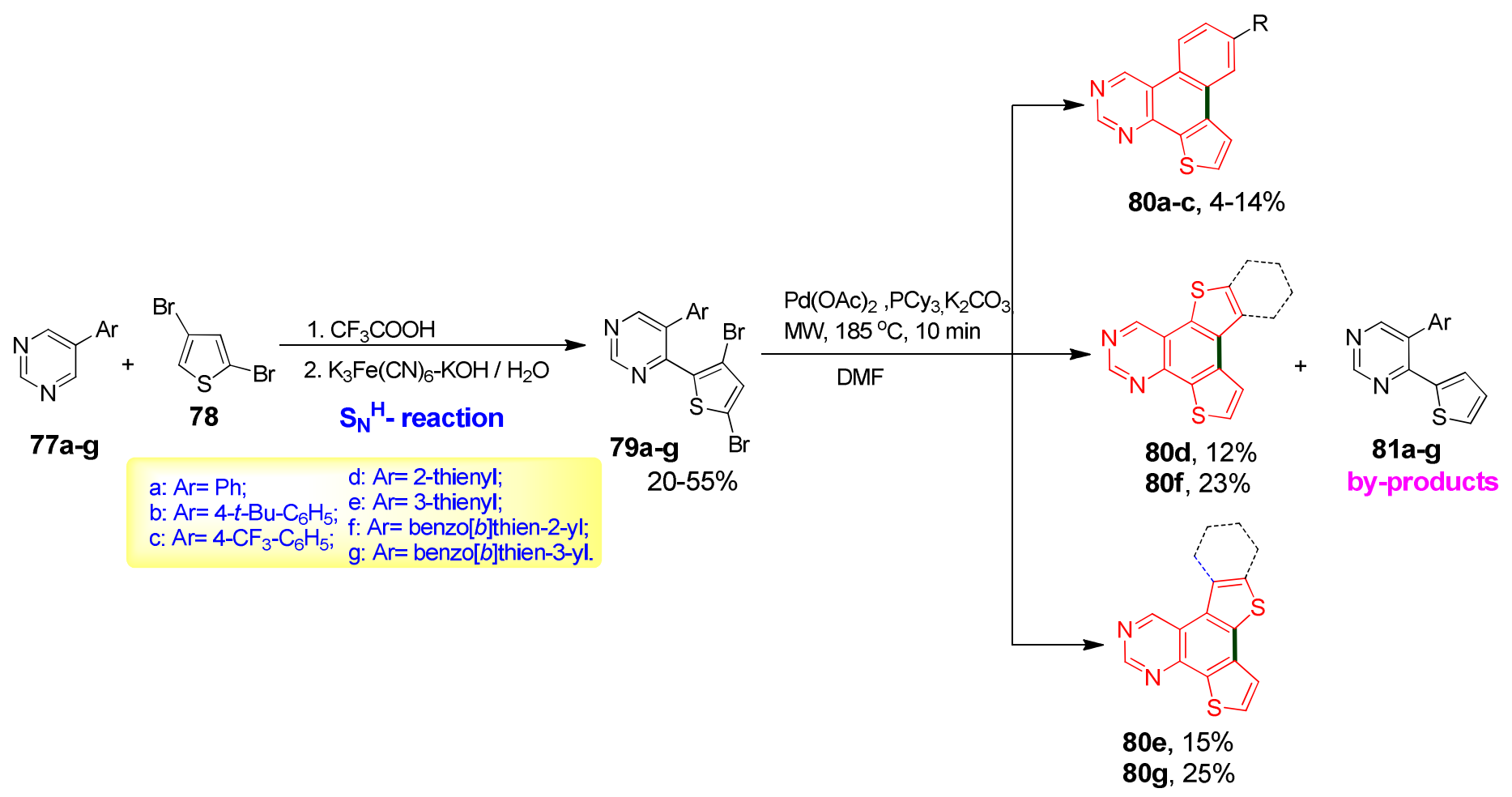

Scheme 26. Synthesis of benzo[f]thieno[3,2-h]quinazoline (80a-c), dithieno[2,3-f:3',2'-h]quinazoline (80d,f) and dithieno[3,2-f:3',2'-h]quinazoline $(\mathbf{8 0} \mathbf{e}, \mathbf{g})$ derivatives via Pd-catalyzed intramolecular cyclization of $79 a-g$ under microwave irradiation.

Poor yields of the target products $\mathbf{8 0}$ obtained for palladium-catalyzed intramolecular arylation of 79a-g prompted the authors to develop a convenient protocol for the syntheses of benzo[f]thieno[3,2- $h]-$ quinazolines (80a-c), dithieno[2,3-f:3',2'-h]quinazolines (80d,f,h,i) and dithieno[3,2-f:3',2'-h]quinazolines $(\mathbf{8 0 e}, \mathbf{g}, \mathbf{j})$ by using the oxidative photocyclization of the corresponding 5-aryl-4-(thiophen-2-yl)pyrimidines (81ac) and 4,5-dithienyl substituted pyrimidines (81d-j) (Scheme 27$).{ }^{101,102}$ It is noteworthy that 8-substituted benzo[gh]dithieno[2,3-e:3',2'-j]perimidines (82a-c) have been obtained from 5-(4-R-phenyl)-4,6-dithiophen-2yl-pyrimidines (83a-c) in good yields by exploiting the same procedure (Scheme 28 ). 

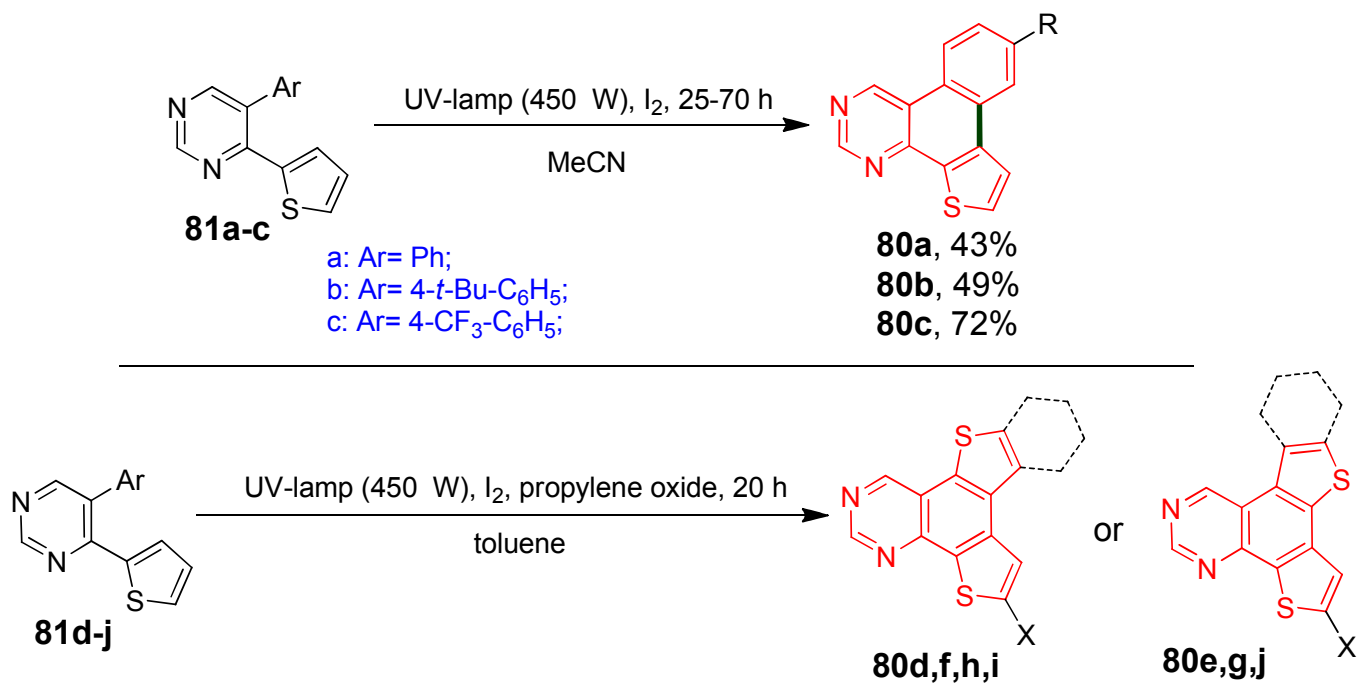

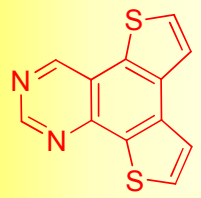

80d, $64 \%$

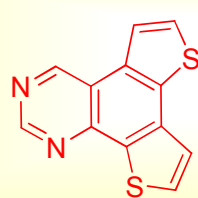

$80 \mathbf{e}, 47 \%$

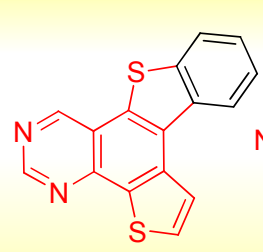

80f, $64 \%$

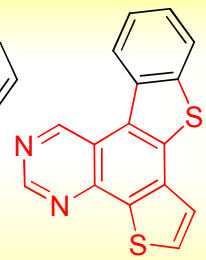

$80 \mathrm{~g}, 22 \%$

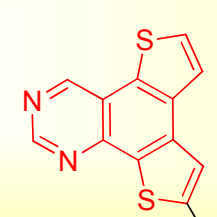

80h, $46 \%$ Br

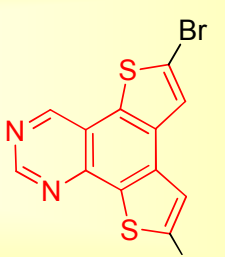

$80 i, 55 \%$

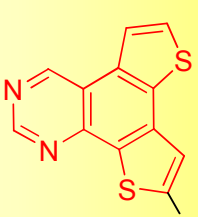

$80 \mathrm{j}, 61 \% \mathrm{Br}$

Scheme 27. Synthesis of benzo[f]thieno[3,2- $h$ ]quinazolines (80a-c), dithieno[2,3-f:3',2'-h]quinazolines $(\mathbf{8 0 d}, \mathbf{f}, \mathbf{h}, \mathbf{i})$ and dithieno[3,2-f:3',2'- $h]$ quinazolines $(\mathbf{8 0} \mathbf{e}, \mathbf{g}, \mathbf{j})$ via the oxidative photocyclization of appropriate 4,5di(hetro)aryl substituted pyrimidines (81a-j).<smiles>[R]c1ccc(-c2c(-c3cccs3)ncnc2-c2cccs2)cc1</smiles>

82a-c

$\mathrm{a}: \mathrm{R}=\mathrm{H} ; \mathrm{b}: \mathrm{R}=t-\mathrm{Bu} ; \mathrm{c}: \mathrm{R}=\mathrm{CF}_{3}$

$83 a, 18 \%$

$83 \mathrm{~b}, 51 \%$

$83 c, 32 \%$

Scheme 28. Synthesis of 8-substituted benzo[gh]dithieno[2,3-e:3',2'-j]perimidines (83a-c) by the oxidative photocyclization of 5-(4-substituted-phenyl)-4,6-dithiophen-2-yl-pyrimidines (82a-c).

\section{Synthesis of Heteropolycyclic Systems, Analogues of 1,4-Diazatriphenylenes}

There are 6 tetracyclic aromatic structures (XXII-XXXII), bearing the 1,4-diazine fragment (see Figure 4). Surprisingly, only dithieno[2,3-f:2',3'-h]quinoxalines (XXXII) have not so far been described in the literature. 


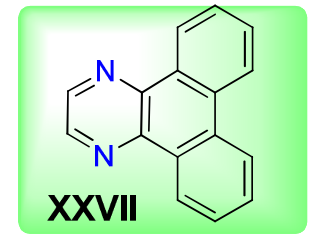

Dibenzo[f,h]quinoxaline

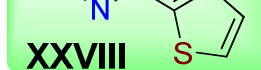

Benzo[f]thieno[3,2- $h]$ quinoxaline

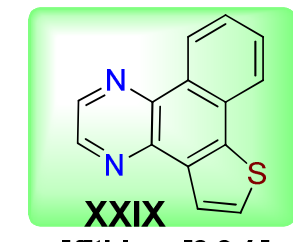

Benzo[f]thieno[2,3- $h]$ quinoxaline

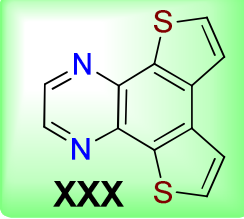

Dithieno[2,3-f:3',2'-h]quinoxaline

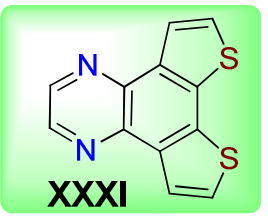

Dithieno[3,2-f:2',3'- $h]$ quinoxaline

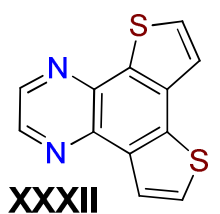

Dithieno[2,3-f:2',3'-h]quinoxaline

Figure 4. The structures of tetracyclic aromatic systems bearing the pyrazine ring.

For the first time the synthesis of dibenzo[f,h]quinoxaline (XXVII) derivatives, e.g. dibenzo[a,c]phenazine (86a), has been carried out by condensation of 9-nitrophenanthrene (84) with aniline (85) in the presence of powdered $\mathrm{NaOH}$ at $170-180{ }^{\circ} \mathrm{C}$ (Scheme 29). ${ }^{103}$

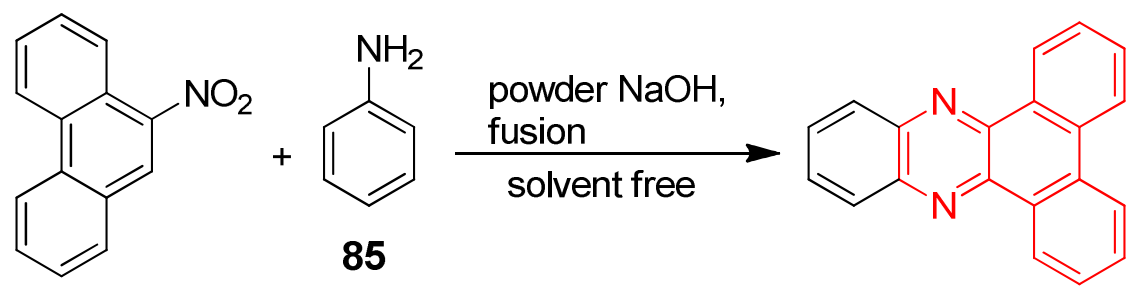

84

$86 a, 80 \%$

Scheme 29. The synthesis of dibenzo[f, $h]$ quinoxaline $\mathbf{8 6 a}$ by the reaction of 9-nitrophenanthrene (84) and aniline (85).

A variety of methods have been developed to prepare dibenzo[f,h]quinoxalines (XXVII), including the most widely used condensation of 1,2-diamines, such as 0 -phenylenediamine (87) and ethylenediamine (88) derivatives, with substituted phenanthrene-9,10-diones (89) (Schemes 30 and 31). The reaction conditions for condensations leading to dibenzo[ $a, c]$ phenazines $(\mathbf{8 6})^{104-159}$ and dibenzo[f, $\left.h\right]$ quinoxalines $(\mathbf{9 0})^{152,153,160-163}$ are summarized in Tables 1 and 2.

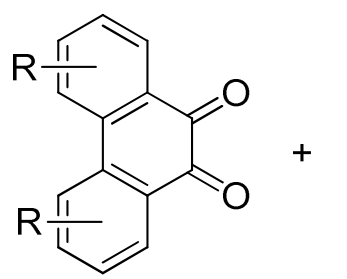

89

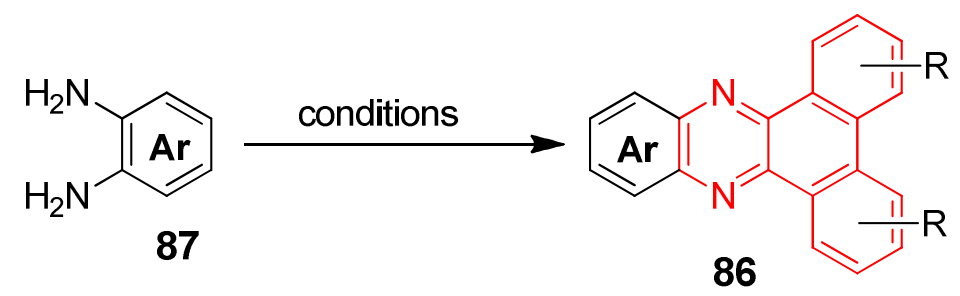

86

Scheme 30. Synthesis of dibenzo[a,c]phenazines (86) by condensation of o-phenylenediamines (87) with substituted phenanthrene-9,10-diones (89). 
Table 1. Selected examples of condensation of 0 -phenylenediamines (87) with phenanthrene-9,10-diones (89)

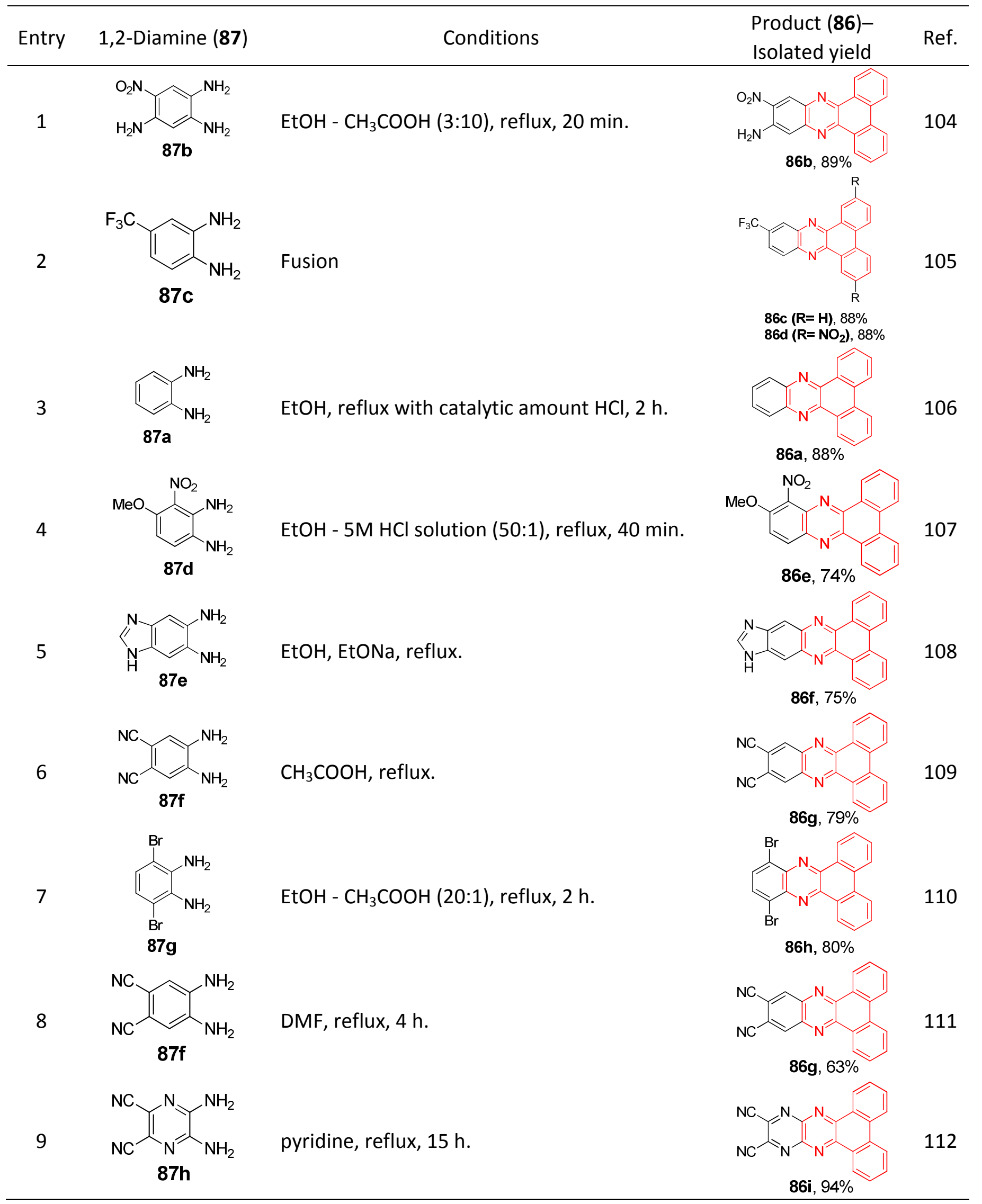


Table 1. Continued

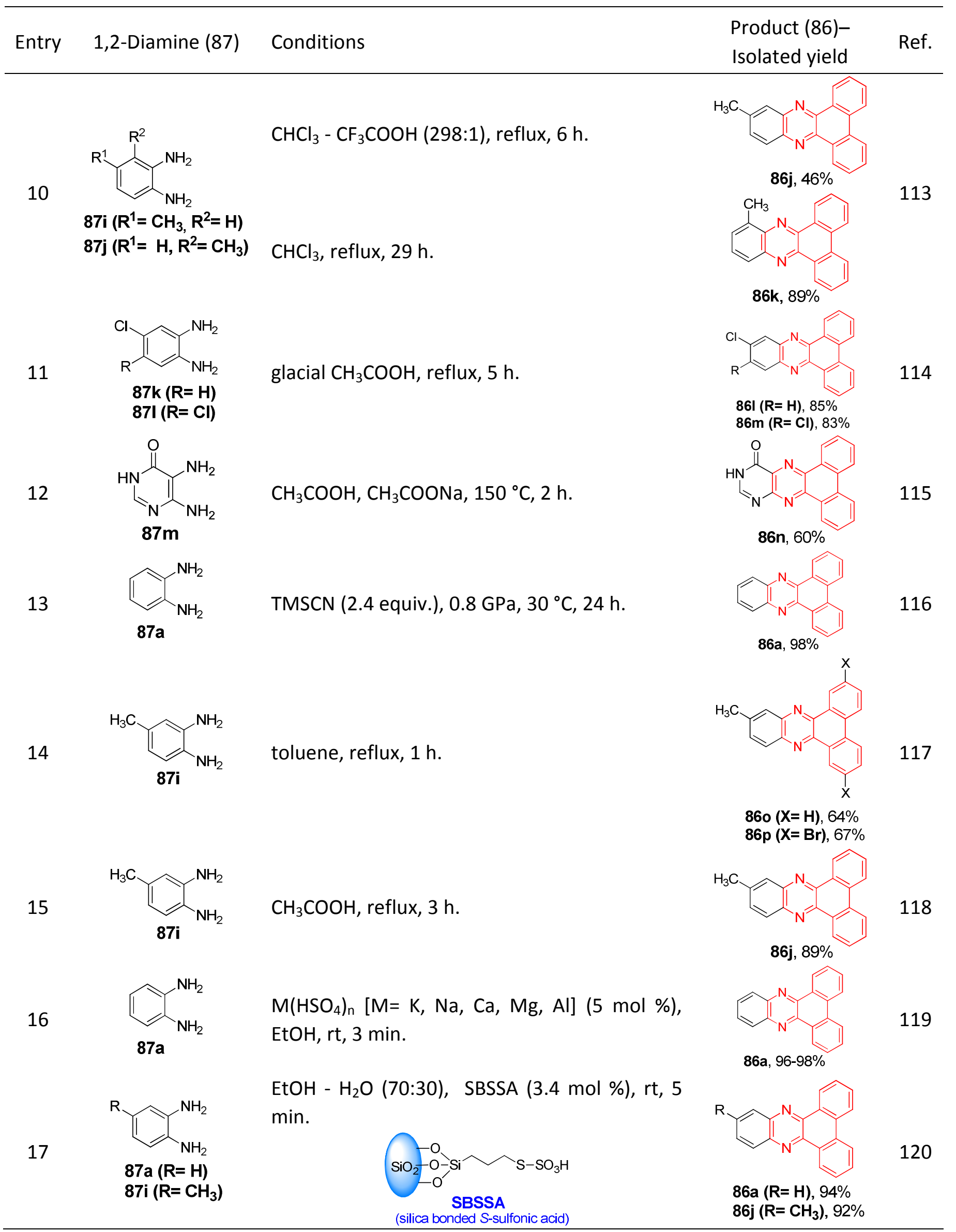


Table 1. Continued

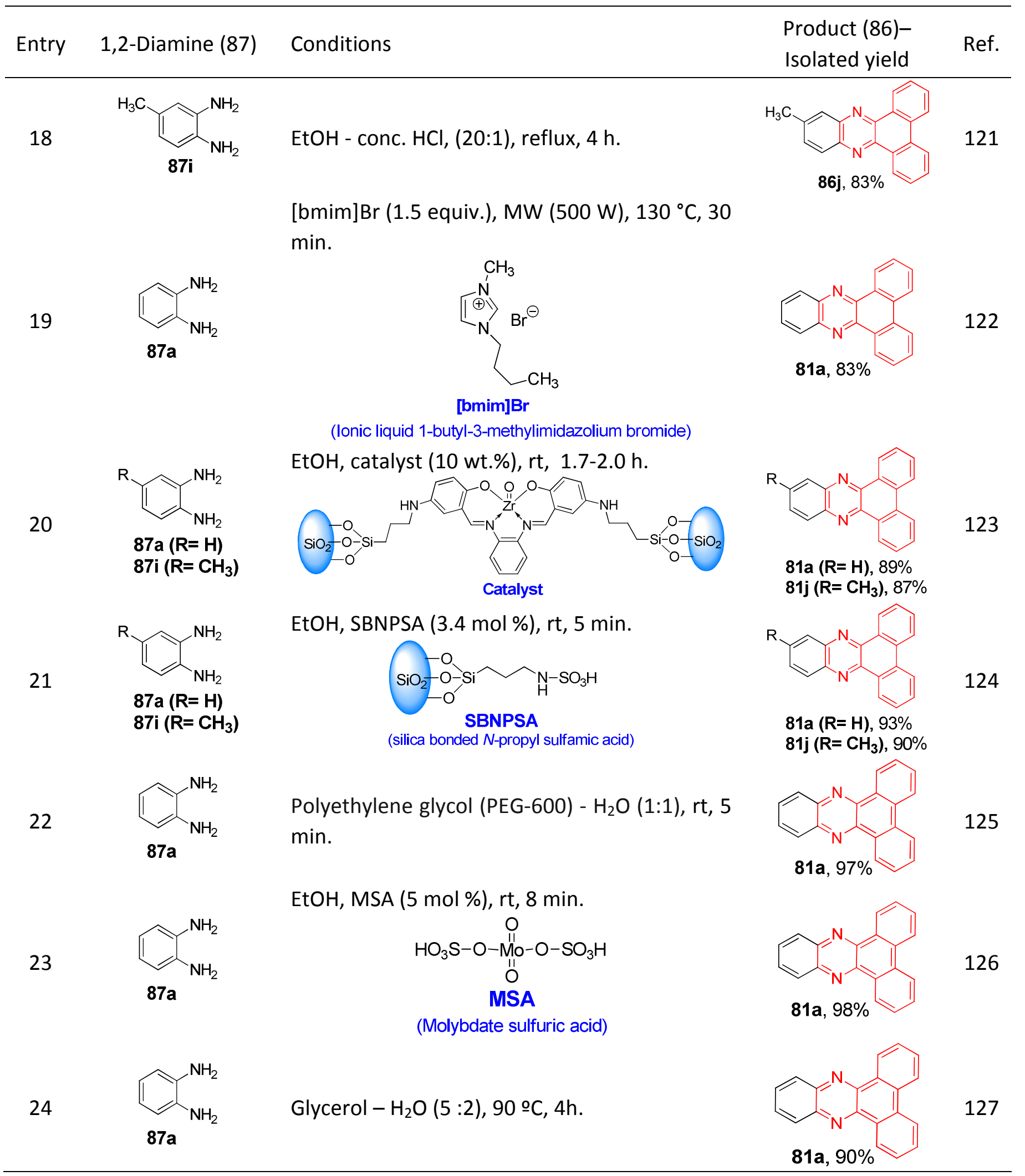


Table 1. Continued

\begin{tabular}{|c|c|c|c|c|}
\hline Entry & 1,2-Diamine (87) & Conditions & $\begin{array}{l}\text { Product (86)- } \\
\text { Isolated yield }\end{array}$ & Ref. \\
\hline 25 & $\begin{array}{l}\text { 87a }(\mathbf{R}=\mathrm{H}) \\
87 \mathrm{i}\left(\mathrm{R}=\mathrm{CH}_{3}\right)\end{array}$ & $\mathrm{EtOH}, \mathrm{MgSO}_{4} \cdot 7 \mathrm{H}_{2} \mathrm{O}(20 \mathrm{~mol} \%), \mathrm{rt}, 15 \mathrm{~min}$. & $\begin{array}{l}81 \mathrm{a}(\mathrm{R}=\mathrm{H}), 90 \\
81 \mathrm{j}\left(\mathrm{R}=\mathrm{CH}_{3}\right)\end{array}$ & 128 \\
\hline 26 & $\begin{array}{l}\text { 87a }\left(\mathrm{R}=\mathrm{H} \mathrm{H}_{2}\right. \\
87 \mathrm{i}\left(\mathrm{R}=\mathrm{CH}_{3}\right)\end{array}$ & $\begin{array}{l}\text { 1,2-Dichloroethane, nano- } \mathrm{TiO}_{2}(2.5 \mathrm{~mol} \%), \mathrm{rt} \text {, } \\
20-25 \mathrm{~min} \text {. }\end{array}$ & $\begin{array}{l}81 \mathrm{a}(\mathrm{R}=\mathrm{H}), 9 \\
81 \mathrm{j}\left(\mathrm{R}=\mathrm{CH}_{3}\right),\end{array}$ & 129 \\
\hline 27 & $87 \mathrm{n} \mathrm{NH}_{2}$ & EtOH, reflux, 2 h. & $\%$ & 130 \\
\hline 28 & $\begin{array}{l}\text { 87a }(\mathbf{R}=\mathrm{H}) \\
87 \mathrm{i}\left(\mathrm{R}=\mathrm{CH}_{3}\right)\end{array}$ & Ball-milling, solvent free, $\mathrm{rt}, 4 \mathrm{~h}$. & $\begin{array}{l}\text { 86a }(R=H) \\
86 j\left(R=C_{3}\right.\end{array}$ & 131 \\
\hline 29 & $87 a$ & $\begin{array}{l}\mathrm{H}_{2} \mathrm{O} \text {, PTSA (5 mol \%), NaPTSA (40 wt.\%), rt, } 7 \\
\text { min. }\end{array}$ & & 132 \\
\hline 30 & $87 a$ & $\begin{array}{l}\text { Solvent free, nano- } \mathrm{SiO}_{2}(0.6 \mathrm{~g} \text { to } 1 \mathrm{mmol} 87 \mathrm{a}) \text {, } \\
\text { grinding, rt, } 10 \mathrm{~min} \text {. }\end{array}$ & & 133 \\
\hline 31 & $\begin{array}{l}\text { 87a }(\mathrm{R}=\mathrm{H}) \\
87 \mathrm{i}\left(\mathrm{R}=\mathrm{CH}_{3}\right)\end{array}$ & $\begin{array}{l}\text { Solvent free, TSA ( } 5 \mathrm{~mol} \% \text { ), grinding, } \mathrm{rt}, 20-22 \\
\text { min. } \\
\qquad \begin{array}{c}\mathrm{HO}_{3} \mathrm{~S}-\mathrm{O}-W_{\|}^{\| \prime}-\mathrm{O}-\mathrm{SO}_{3} \mathrm{H} \\
\mathrm{OSA} \\
\text { (Tungstate sulfuric acid) }\end{array}\end{array}$ & $\begin{array}{l}86 \mathbf{a}(\mathrm{R}=\mathrm{H}), 91 \% \\
86 \mathrm{j}\left(\mathrm{R}=\mathrm{CH}_{3}\right), 90 \%\end{array}$ & 134 \\
\hline
\end{tabular}


Table 1. Continued

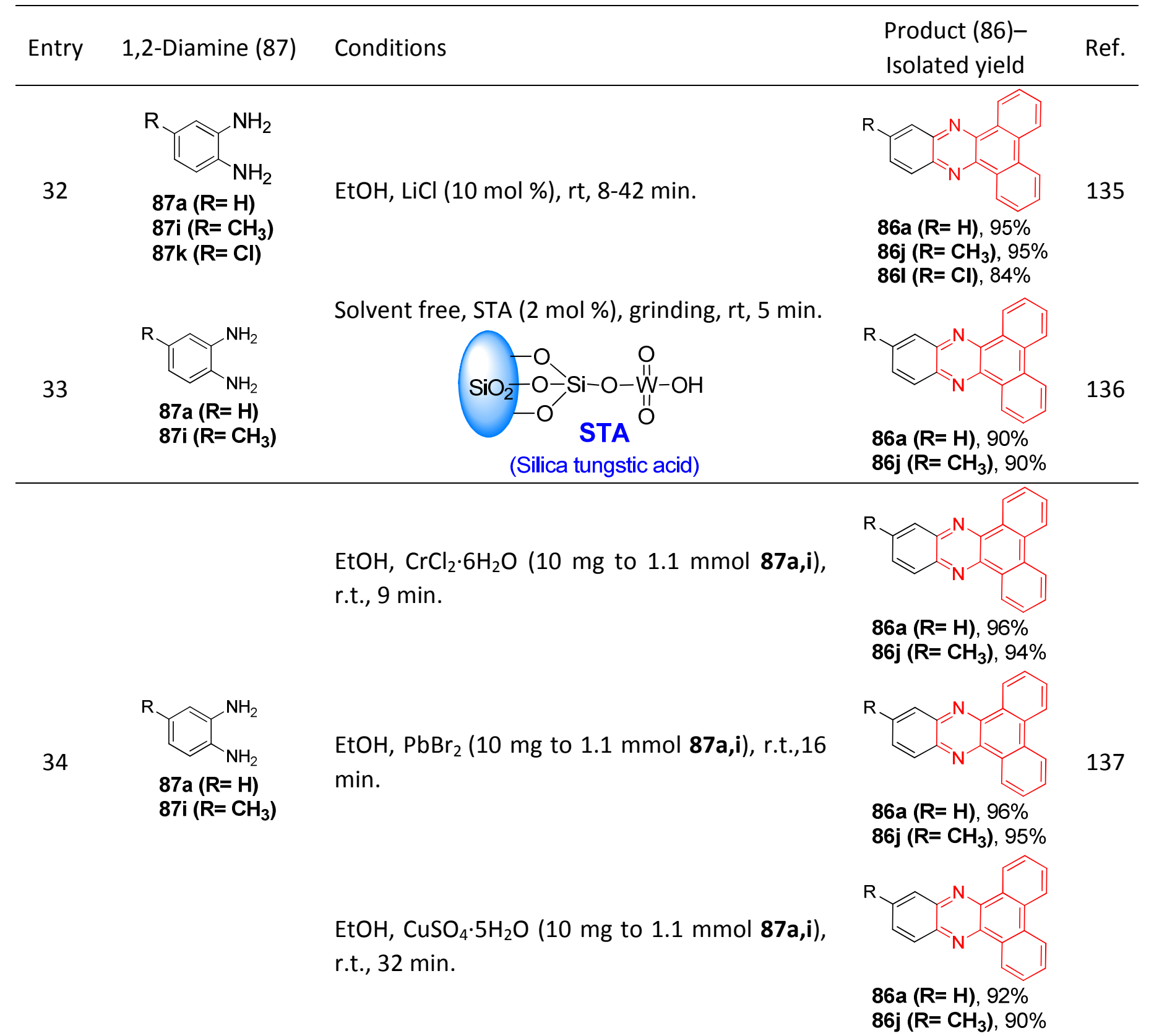

Solvent free, DBH (6 mol \%), oil bath, 110 ㅇ,

35<smiles>Nc1ccccc1N</smiles>

87a $30 \mathrm{~min}$.
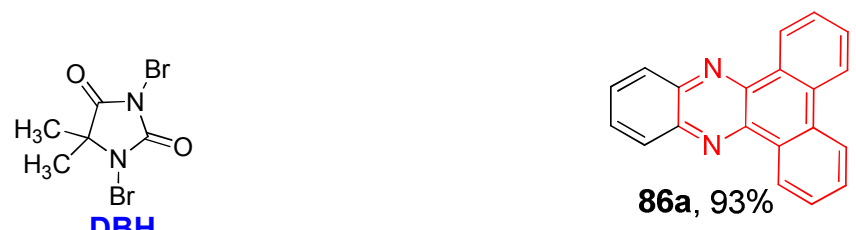

(1,3-Dibromo-5,5-dimethylhyndantoin)<smiles>Nc1ccccc1N</smiles>

EtOH- $\mathrm{H}_{2} \mathrm{O}$ (7:3), PhOH (20 mol \%), rt, 2 min.

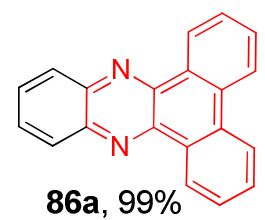

139 
Table 1. Continued

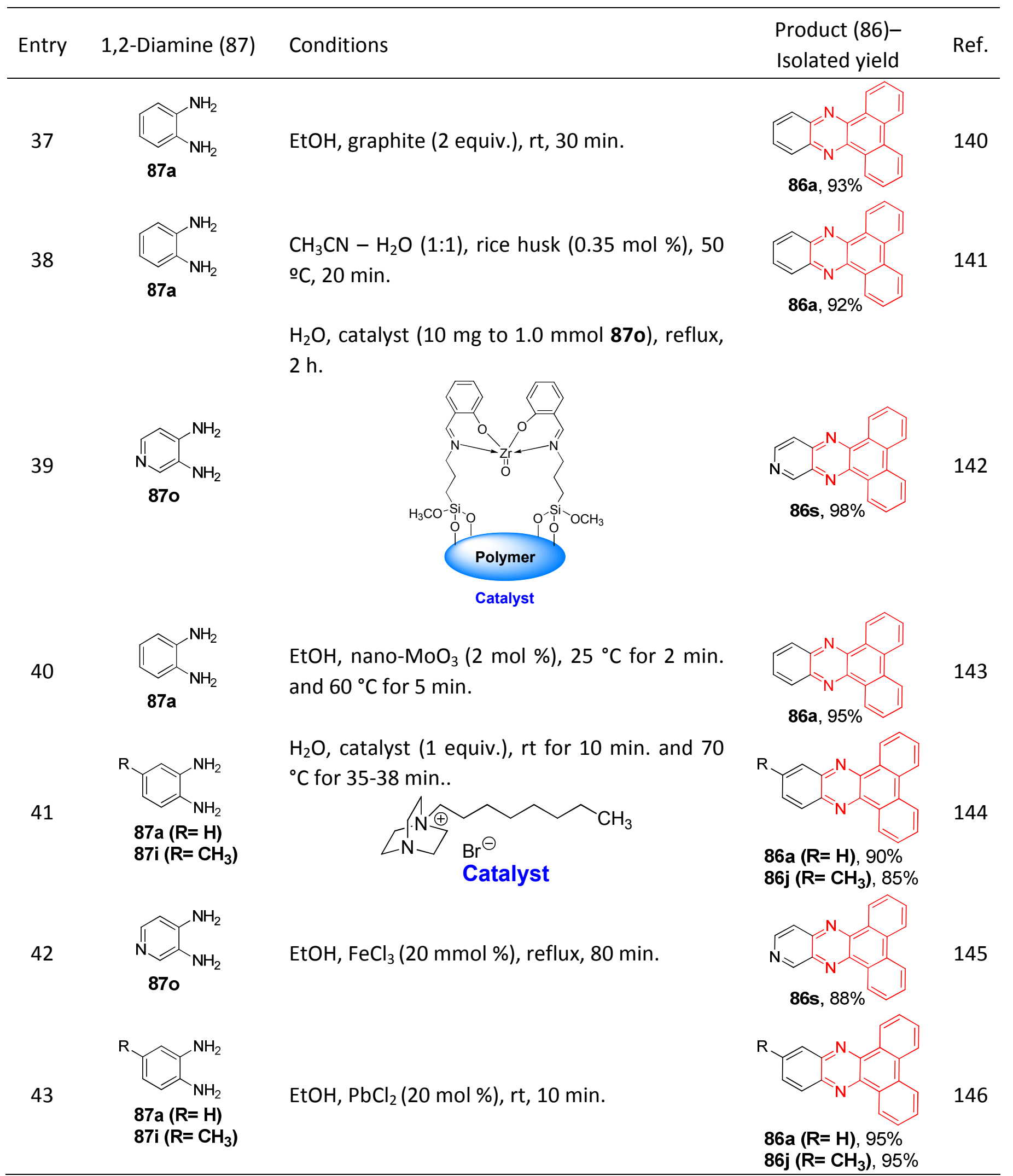


Table 1. Continued

\begin{tabular}{|c|c|c|c|c|}
\hline Entry & 1,2-Diamine (87) & Conditions & $\begin{array}{l}\text { Product (86)- } \\
\text { Isolated yield }\end{array}$ & Ref. \\
\hline 44 & $87 \mathrm{a}$ & Solvent free, nano-ZnO (1.1 mol \%), rt, $20 \mathrm{~min}$. & & 147 \\
\hline 45 & $\begin{array}{l}87 a(R=H) \\
87 i\left(R=C_{3}\right)\end{array}$ & $\begin{array}{l}\mathrm{H}_{2} \mathrm{O} \text {, ionic liquid }[\mathrm{Hmim}] \mathrm{HSO}_{4}(10 \mathrm{~mol} \%), \mathrm{rt}, 3 \\
\text { min. } \\
\text { (1-Hydrogen-3-methylimidazolium hydrogen sulfate) } \\
\left.\mathrm{H}_{2} \mathrm{O} \text {, ionic liquid [ } \mathrm{Hmim}\right] \mathrm{Cl}(10 \mathrm{~mol} \%), \mathrm{rt}, 7-10 \\
\text { min. } \\
\text { (1-Hydrogen-3-methylimidazolium chloride) } \\
\mathrm{H}_{2} \mathrm{O} \text {, ionic liquid }\left[\mathrm{Hnhp]} \mathrm{HSO}_{4}(10 \text { mol \%), rt, } 7\right. \\
\text { min. } \\
\text { (2-Pyrrolidonium hydrogen sulfate) }\end{array}$ & $\begin{array}{l}86 a(R=H), 94 \% \\
86 j\left(R=C_{3}\right), 90^{\circ}\end{array}$ & 148 \\
\hline 46 & $\begin{array}{l}\mathrm{NH}_{2} \\
87 \mathrm{i}\left(\mathrm{R}=\mathrm{CH}_{3}\right) \\
87 \mathrm{p}\left(\mathrm{R}=\mathrm{NO}_{2}\right)\end{array}$ & $\begin{array}{l}\mathrm{EtOH}-\mathrm{H}_{2} \mathrm{O}(3: 2), \mathrm{Zr}(\mathrm{OTf})_{4}(10 \mathrm{~mol} \%), \mathrm{rt}, 20-30 \\
\text { min. }\end{array}$ & $\begin{array}{l}\text { 86j }\left(\mathrm{R}=\mathrm{CH}_{3}\right), 95 \\
86 \mathrm{t}\left(\mathrm{R}=\mathrm{NO}_{2}\right), 96\end{array}$ & 149 \\
\hline 47 & $87 a \mathrm{NH}_{2}$ & $\mathrm{EtOH}$, nano- $-\mathrm{ZrO}_{2}(3.2 \mathrm{~mol} \%), 60^{\circ} \mathrm{C}, 7 \mathrm{~min}$. & & 150 \\
\hline
\end{tabular}


Table 1. Continued

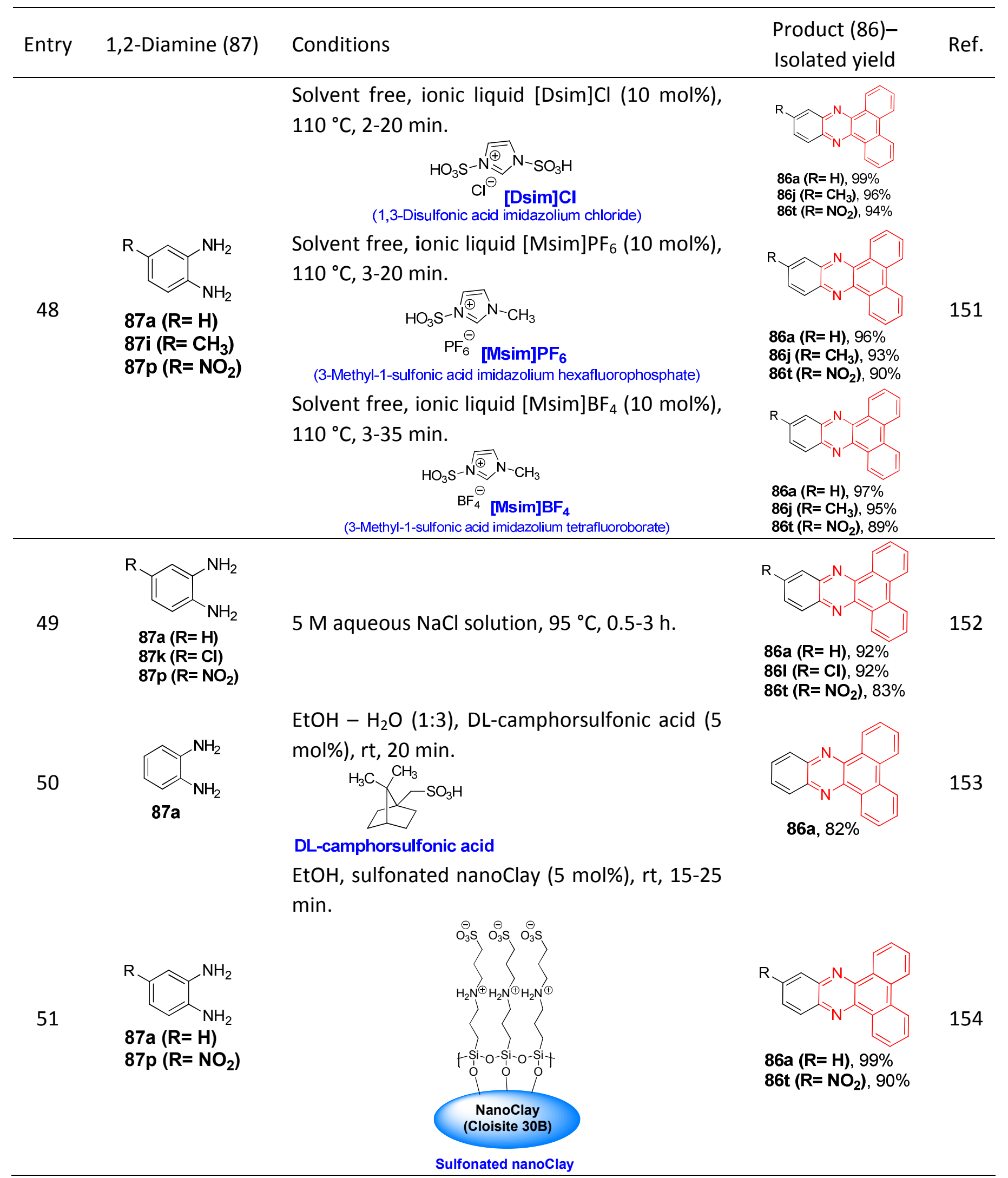


Table 1. Continued

\begin{tabular}{|c|c|c|c|c|}
\hline Entry & 1,2-Diamine (87) & Conditions & $\begin{array}{l}\text { Product (86)- } \\
\text { Isolated yield }\end{array}$ & Ref. \\
\hline 52 & $\begin{array}{l}\text { 87a }(\mathrm{R}=\mathrm{H}) \\
\text { 87i }\left(\mathrm{R}=\mathrm{CH}_{3}\right) \\
\text { 87p }\left(\mathrm{R}=\mathrm{NO}_{2}\right)\end{array}$ & $\begin{array}{l}\text { EtOH }-\mathrm{H}_{2} \mathrm{O}(7: 3) \text {, phthalic acid (5 mol\%), rt, 2- } \\
20 \mathrm{~min} .\end{array}$ & $\begin{array}{l}\text { 86a }(R=H), 99 \% \\
\text { 86j }\left(R=C H_{3}\right), 95 \% \\
\text { 86t }\left(R=\mathrm{NO}_{2}\right), 93 \%\end{array}$ & 155 \\
\hline 53 & $\begin{array}{l}\text { 87a }(\mathbf{R}=\mathrm{H}) \\
87 \mathrm{i}\left(\mathrm{R}=\mathrm{CH}_{3}\right)\end{array}$ & $\begin{array}{l}\mathrm{H}_{2} \mathrm{O} \text {, propylsulfonic acid functionalized } \\
\text { nanozeolite clinoptilolite (10 } \mathrm{mg} \text { to } 1.0 \mathrm{mmol} \\
87 \mathrm{a}, \mathrm{i}), \mathrm{rt}, 10-15 \mathrm{~min} \text {. }\end{array}$ & $\begin{array}{l}\text { 86a }(R=H), 92 \% \\
\text { 86j }\left(R=C_{3}\right), 92 \%\end{array}$ & 156 \\
\hline 54 & $\begin{array}{l}87 a(\mathrm{R}=\mathrm{H}) \\
87 \mathrm{i}\left(\mathrm{R}=\mathrm{CH}_{3}\right) \\
87 \mathrm{p}\left(\mathrm{R}=\mathrm{NO}_{2}\right)\end{array}$ & $\begin{array}{l}\mathrm{H}_{2} \mathrm{O}-\mathrm{CH}_{3} \mathrm{COOH}-\mathrm{DABCO}(3: 1: 1), 80^{\circ} \mathrm{C}, 20-40 \\
\min .\end{array}$ & $\begin{array}{l}\text { 86a }(R=H), 90 \% \\
\text { 86j }\left(R=\mathrm{CH}_{3}\right), 82 \% \\
\text { 86t }\left(R=\mathrm{NO}_{2}\right), 82 \%\end{array}$ & 157 \\
\hline 55 & $87 a$ & $\begin{array}{l}\text { Solvent free, sulfonated rice husk ash (15 mg } \\
\text { to } 1.0 \mathrm{mmol} 87 \mathrm{a}), 80^{\circ} \mathrm{C}, 10 \mathrm{~min} \text {. }\end{array}$ & & 158 \\
\hline 56 & $\begin{array}{l}87 a(\mathrm{R}=\mathrm{H}) \\
87 \mathrm{p}\left(\mathrm{R}=\mathrm{NO}_{2}\right)\end{array}$ & $\begin{array}{l}\text { EtOH, nanoparticles (4 } \mathrm{mg} \text { to } 1.5 \mathrm{mmol} 87 \mathrm{a}, \mathrm{p} \text { ), } \\
60^{\circ} \mathrm{C}, 3-60 \mathrm{~min} \text {. } \\
\text { (A zirconium Schiff base complex immobilized on starch-coated } \\
\text { maghemite nanoparticles) }\end{array}$ & $\begin{array}{l}\text { 86a }(R=H), 97 \% \\
\text { 86t }\left(R=\mathbf{N O}_{2}\right), 88 \%\end{array}$ & 159 \\
\hline
\end{tabular}<smiles>[R]c1cccc2c1-c1ccccc1C(=O)C2=O</smiles>

Scheme 31. Synthesis of dibenzo[f,h]quinoxaline (90) by condensation of ethylenediamines (88) with substituted phenanthren-9,10-diones (89). 
Table 2. Selected examples of the condensation of ethylenediamines (88) with phenanthrene-9,10-dione (89)

\begin{tabular}{|c|c|c|c|c|}
\hline Entry & 1,2-Diamine (88) & Conditions & $\begin{array}{l}\text { Product }(90)- \\
\text { Isolated yield }\end{array}$ & Ref. \\
\hline 1 & $\begin{array}{l}\mathrm{NH}_{2} \\
\mathbf{8 8 a}\end{array}$ & $\begin{array}{l}\mathrm{EtOH}-\mathrm{CH}_{3} \mathrm{COOH}(3: 10) \text {, reflux, } \\
20 \mathrm{~min} .\end{array}$ & $90 a, 78 \%$ & 160 \\
\hline 2 & ${ }_{\mathbf{8 8}}{ }_{\mathrm{NH}_{2}}$ & $\begin{array}{l}\text { EtOH, reflux with catalytic amount } \mathrm{CH}_{3} \mathrm{COOH} \text {, } \\
2 \mathrm{~h} \text {. }\end{array}$ & & 161 \\
\hline 3 & ${ }_{88 \mathrm{C}}^{\mathrm{NC}} \overbrace{\mathrm{NH}_{2}}^{\mathrm{NH}_{2}}$ & EtOH, PTSA (0.26 mol \%), reflux, $5 \mathrm{~h}$. & & 162 \\
\hline 4 & {$\left[\begin{array}{l}\mathrm{NH}_{2} \\
\mathrm{NH}_{2} \\
\mathbf{8 8 a}\end{array}\right.$} & $5 \mathrm{M}$ aqueous $\mathrm{NaCl}$ solution, $95^{\circ} \mathrm{C}, 1 \mathrm{~h}$. & $90 \mathbf{a}, 82 \%$ & 152 \\
\hline 5 & {$\left[\begin{array}{l}\mathrm{NH}_{2} \\
\\
\mathrm{NH}_{2} \\
\mathbf{8 8 a}\end{array}\right.$} & $\begin{array}{l}\text { EtOH }-\mathrm{H}_{2} \mathrm{O}(1: 3), \mathrm{DL} \text {-camphorsulfonic acid (5 } \\
\text { mol \%), rt, } 5 \text { min. }\end{array}$ & $90 a$ & 153 \\
\hline 6 & $\overbrace{\mathbf{8 8 a}}^{\mathrm{NH}_{2}} \begin{array}{l}\mathrm{NH}_{2} \\
\end{array}$ & $\begin{array}{l}\text { 1. Toluene, reflux, } 24 \mathrm{~h} \text {; } \\
\text { 2. Toluene, } \mathrm{MnO}_{2} \text { ( } 2.3 \text { equiv.), reflux. }\end{array}$ & $90 a, 86 \%$ & 163 \\
\hline
\end{tabular}

In addition to this well-known condensation reaction, Rabinovitz et al. ${ }^{164,165}$ have designed a new synthetic approach to dibenzo[a,c]phenazines (86), based on the reductive coupling reaction of 2,3-diphenyl substituted quinoxalines $(\mathbf{9 1} \mathbf{a}, \mathbf{q}, \mathbf{t}, \mathbf{u})$, proceeding with graphite-potassium intercalate $\left(\mathbf{C}_{\mathbf{8}} \mathbf{K}\right)$ in dry tetrahydrofuran $(\mathrm{THF})$ or dimethoxyethane (DME) at room temperature (Scheme 32). A plausible mechanism for the ring closure reaction has been described in the literature. ${ }^{165,166}$ 


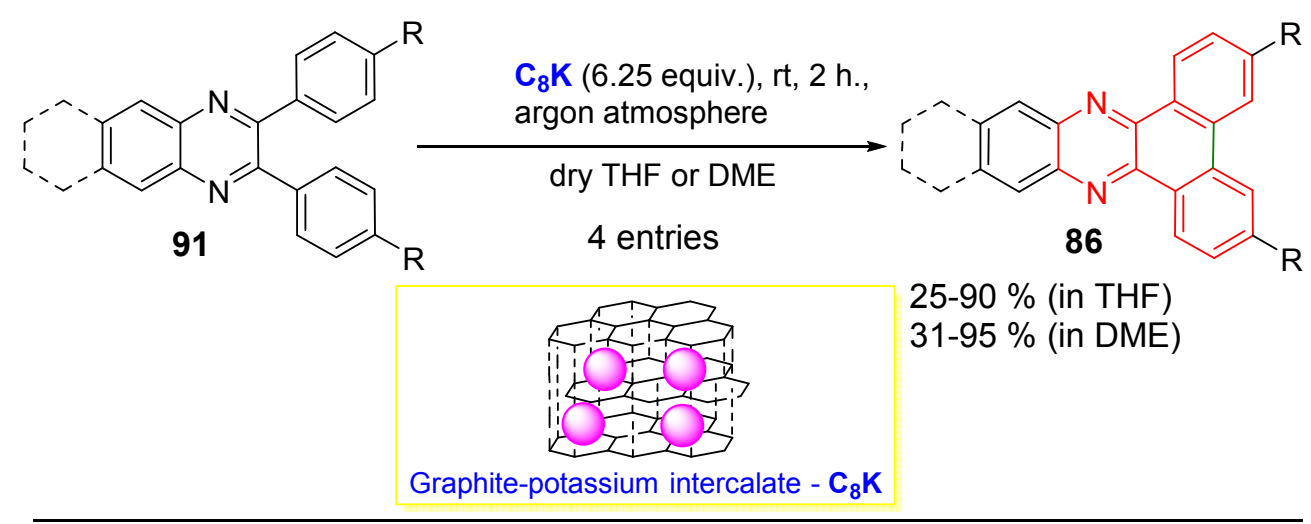<smiles>CC(C)(C)O[Na]</smiles>

$75 \%$ (in THF) $95 \%$ (in DME)

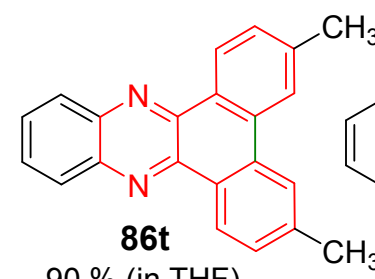

$90 \%$ (in THF) $90 \%$ (in DME)
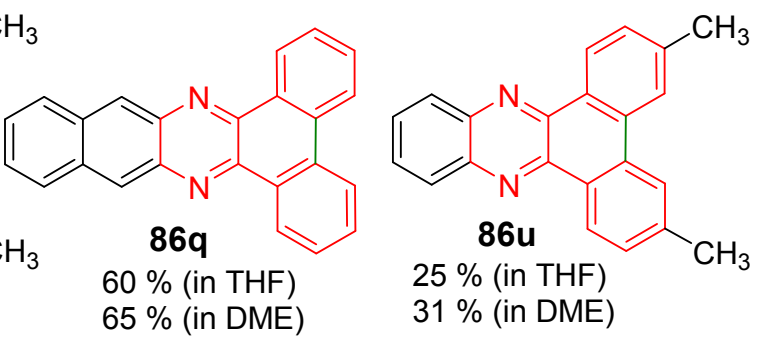

Scheme 32. Synthesis of dibenzo[a,c]phenazines (86) by the reductive coupling reaction of 2,3-diphenyl substituted quinoxalines $(\mathbf{9 1} \mathbf{a}, \mathbf{q}, \mathbf{t}, \mathbf{u})$, proceeding with graphite-potassium intercalate $\left(\mathbf{C}_{\mathbf{8}} \mathbf{K}\right)$ in dry tetrahydrofuran (THF) or dimethoxyethane (DME). ${ }^{165}$

Photocyclization is also an efficient synthetic tool for construction of dibenzo[f, $h]$ quinoxalines (XXVII). For example, 2-methoxydibenzo[f,h]quinoxaline (93) has been obtained in a high yield by irradiating 2-(biphenyl-2yl)-5-methoxypyrazine (92) with UV-light in the presence of iodine, as oxidant, and propylene oxide, as an acid scavenger (Scheme 33). ${ }^{52}$<smiles>COc1ncc(-c2ccccc2-c2ccccc2)cn1</smiles>

Scheme 33. Synthesis of 2-methoxydibenzo[f,h]quinoxaline (93) by the oxidative photocyclization of 2(biphenyl-2-yl)-5-methoxypyrazine (92).

There is only one publication ${ }^{166}$ reporting the synthesis of benzo[f]thieno[3,2-h]quinoxalines (XXVIII). Benzo[f]thieno[3,2-h]quinoxalines (96a,b and $\mathbf{9 7 a , b}$ ) have been prepared in $37-98 \%$ overall yields by condensation of 9-dibutylaminobenzo[b]naphtho[1,2- $d$ ] thiophen-5,6-dione (94) with 3,4-diaminobenzoic acid (95a) or 2,3-diamino-5-bromopyridine (95b) in acetic acid at $110^{\circ} \mathrm{C}$ (Scheme 34). ${ }^{167}$ 


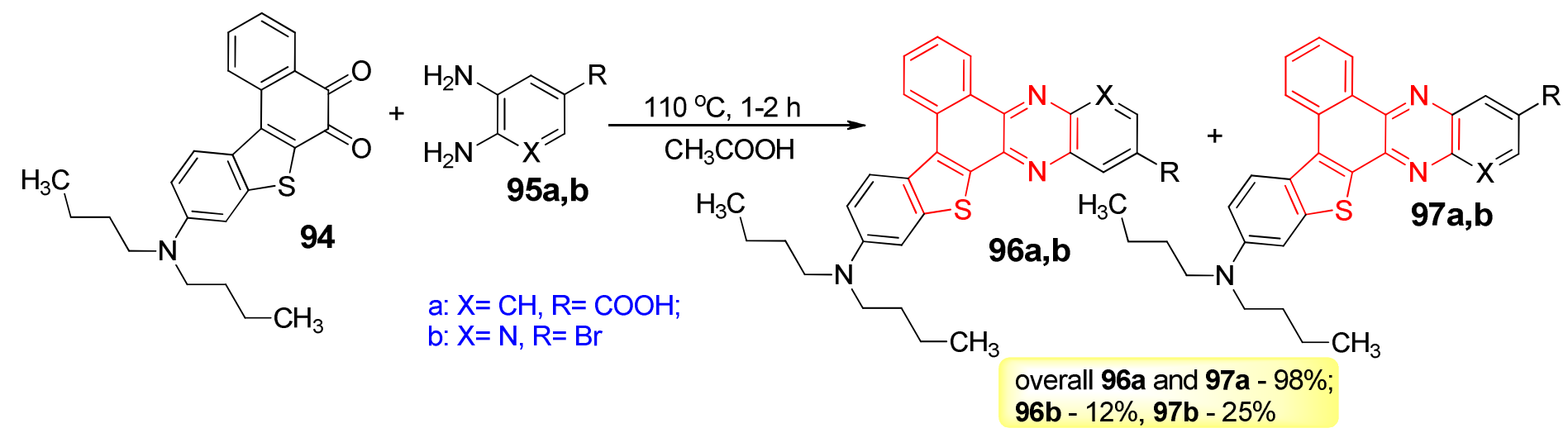

Scheme 34. Synthesis of benzo[f]thieno[3,2- $h$ ]quinoxalines $(\mathbf{9 6 a}, \mathbf{b}$ and $\mathbf{9 7} \mathbf{a}, \mathbf{b})$ by condensation of 9 -dibutylaminobenzo[b]naphtho[1,2-d]thiophene-5,6-dione (94) with 3,4-diaminobenzoic acid (95a) or 2,3-diamino-5bromopyridine (95b).

Compounds of the benzo[f]thieno[2,3- $h]$ quinoxaline (XXIX) series are also scarcely presented in the literature. There are only four references concerning the synthesis of XXIX skeleton. ${ }^{168-171}$ The most common procedure for the synthesis of benzo[f]thieno[2,3- $h$ ]quinoxalines (100a-d) is oxidation of naphtho[1,2-b]thiophenes (98a-d) into the corresponding naphtho[1,2-b]thiophen-4,5-diones (99a-d) with chromic acid, followed by treatment with o-phenylenediamine (87a) (Scheme 35).

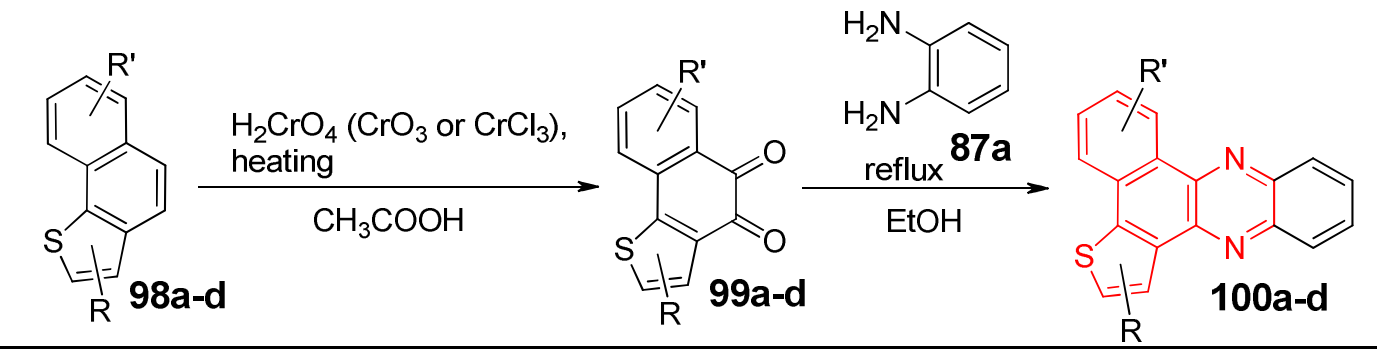

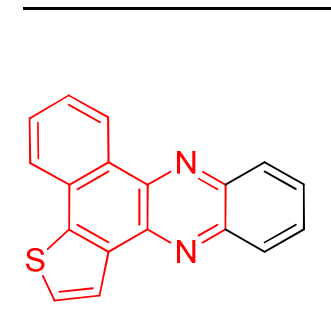

100a (Ref. 168)

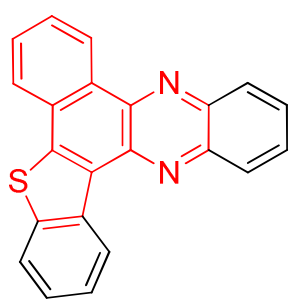

100b (Ref. 169)

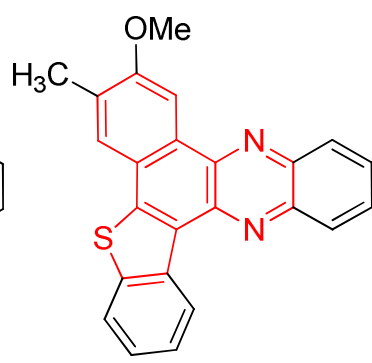

100c (Ref. 170)

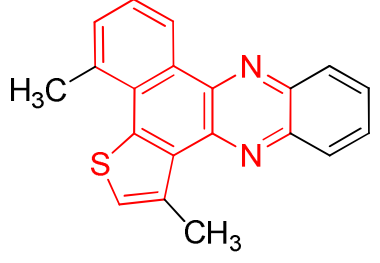

100d, 29\% (Ref.171)

Scheme 35. Synthesis of benzo[f]thieno[2,3-h]quinoxaline derivatives (100a-d).

The dithieno[2,3-f:3',2'-h]quinoxaline ( $\mathbf{X X X})$ skeleton can be constructed by two general methods. The first synthetic protocol starts from 3,3'-bithiophene (101), which can be converted readily into benzo[1,2-b:4,- $b$ ']dithiophene-4,5-dione (103a) through the ring-closing reaction with oxalyl dichloride (102), proceeding in refluxing 1,2-dichloroethane. Bromination of 103a affords 2,7-dibromobenzo[1,2-b:4,3-b]d dithiophene-4,5dione (103b) in a high yield. Condensation of the latter compound with substituted 1,2-phenylenediamine (87) results in the desired dithieno[2,3-a:3',2'-c] phenazine derivative (104a-f) (Scheme 36). ${ }^{172-176}$ 


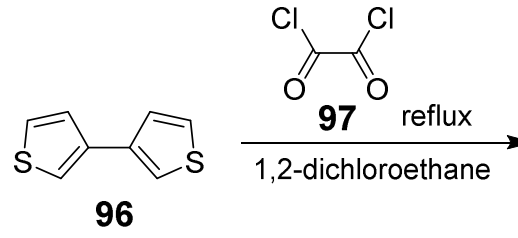
96

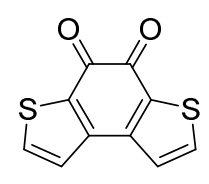

98a, $85 \%$
$\mathrm{Br}_{2}$ (2.05 equiv.), refluxe, $10 \mathrm{~h}$ $\mathrm{CHCl}_{3}-\mathrm{CH}_{3} \mathrm{COOH}(1: 1)$<smiles>[X]c1cc2c3cc([X])sc3c3nc4c([R])c([R])c([R])c([R])c4nc3c2s1</smiles>

99a (R= R' = X= H), Ref. 176

99b (R=X= H, R'= Br), Ref. 176

99c $\left(R=B r, R^{\prime}=X=H\right), 88 \%$, Refs. 175 and 176

99d (R= R'= H, $\mathbf{X = B r}$ ), 67-80\%, Refs. 173, 174 and 176

99e (R= $\left.\mathrm{CH}_{3}, \mathbf{R}^{\prime}=\mathbf{H}, \mathbf{X}=\mathbf{B r}\right), 63 \%$, Ref. 172

99f $\left(R=C_{6} H_{13}, R^{\prime}=\mathbf{H}, X=B r\right), 50 \%$, Ref. 172

Scheme 36. Synthesis of dithieno[2,3-a:3',2'-c]phenazine derivatives (104a-f).

It is noteworthy that tetrathienophenazine derivatives $(\mathbf{1 0 6} \mathbf{a}, \mathbf{b})$ containing two dithieno[2,3-f:3',2'h] quinoxaline (XXX) skeletons have been obtained in a similar manner (Scheme 37). ${ }^{177}$<smiles>[R]c1cc2c(s1)C(=O)C(=O)c1sc([R16])cc1C2=O</smiles>

103a,b

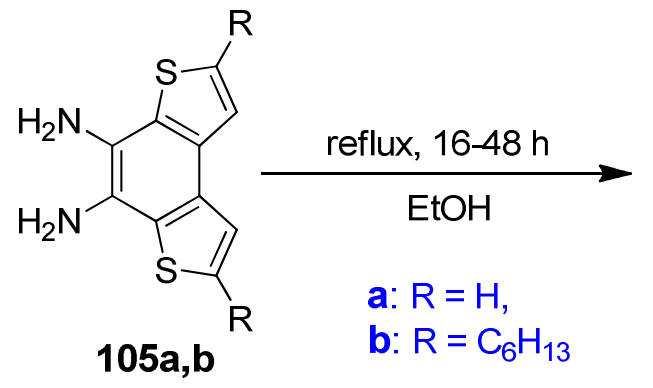

a: $\mathrm{R}=\mathrm{H}$, $105 a, b$<smiles></smiles>

106b, $40 \%$

Scheme 37. Synthesis of 2,5,9,12-tetrasubstituted tetrathieno[2,3-a:3',2'-c:2",3"-h:3"',2"'-j]phenazines (106a,b).

The second synthetic pathway to dithieno[2,3-f:3',2'-h]quinoxalines (XXXX) involves the oxidative cyclodehydrogenation of 2,3-di(thiophen-2-yl)pyrazines (107 or 108) through the Scholl reaction, proceeding in the presence of iron(III) chloride, as an oxidant (Scheme 38$),{ }^{178}$ or it can be based on the oxidative photocyclization in the presence of iodine, as oxidant (Scheme 39). ${ }^{179}$

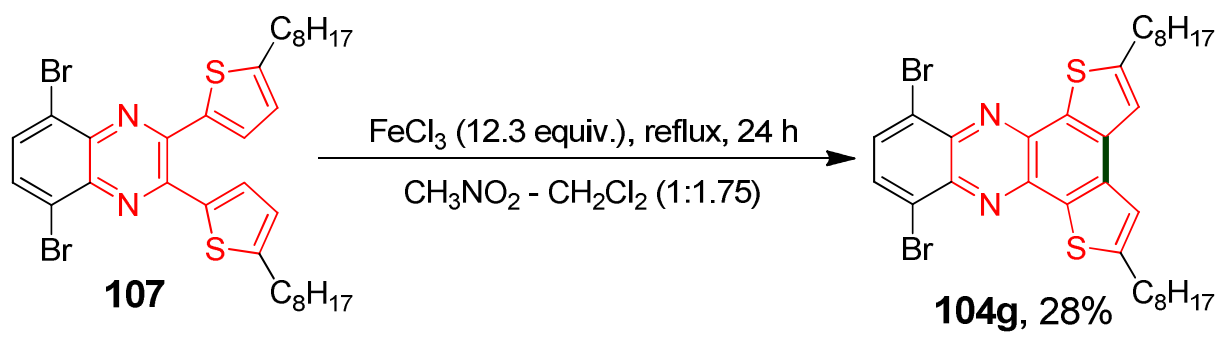

Scheme 38. Synthesis of dithieno[2,3-f:3',2'-h]quinoxaline (XXXX) skeleton by using the Scholl reaction. 


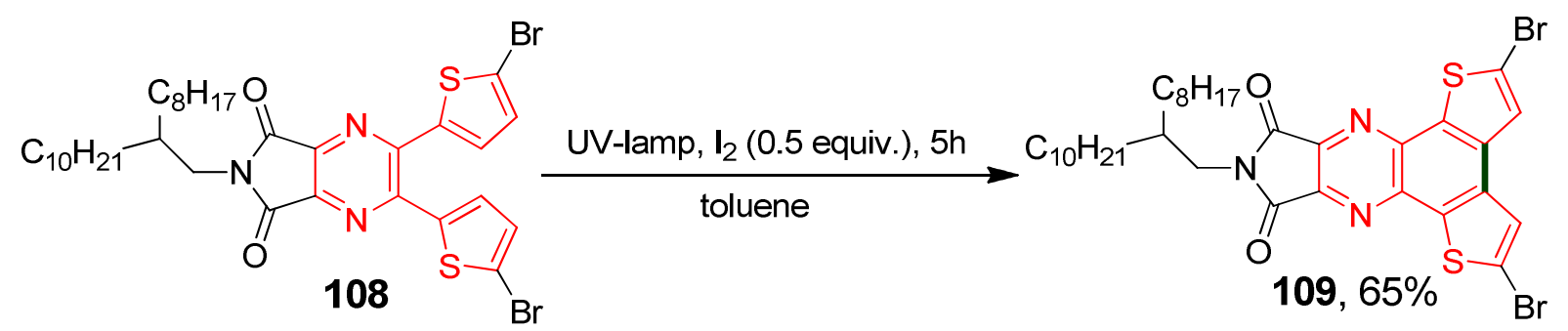

Scheme 39. Synthesis of dithieno[2,3-f:3',2'-h]quinoxaline (XXX) skeleton using oxidative photocyclization.

As for the synthesis of dithieno[3,2-f:2',3'-h]quinoxalines (XXXX) is concerned, there are only two examples showing how to obtain these structures via the oxidative photocyclization of the corresponding 2,3-di(thien-3$\mathrm{yl}$ )pyrazine derivatives $(\mathbf{1 1 0} \mathbf{a}, \mathbf{b})$. The reaction proceeds in the presence of iodine (as oxidant) on irradiation with a 200W mercury lamp with an additional bubbling of air through the reaction mixture for 12 hours. The target dithieno[3,2-f:2',3'-h]quinoxaline derivatives $(\mathbf{1 1 1} \mathbf{a}, \mathbf{b})$ have been obtained in moderate yields (Scheme 40). ${ }^{180,181}$

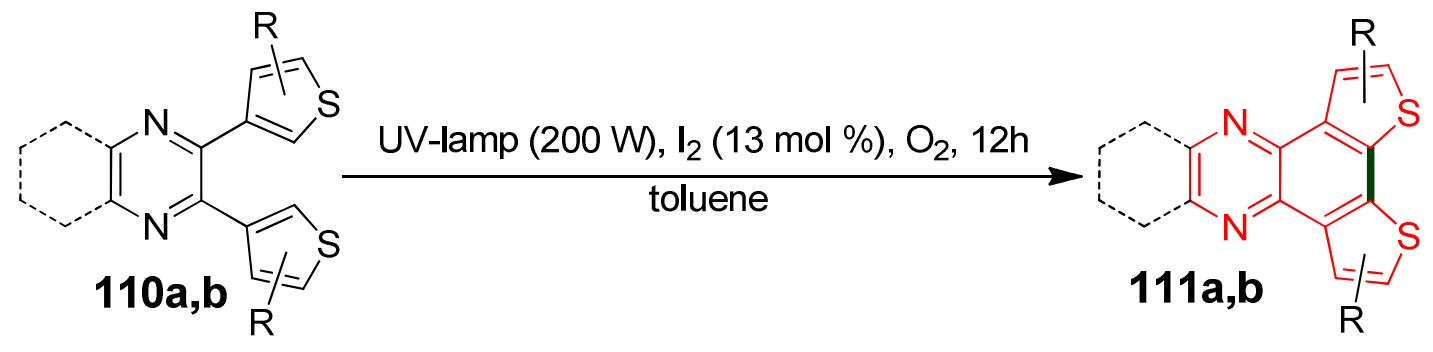

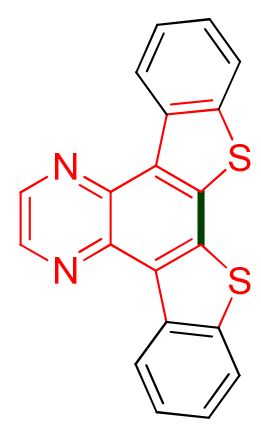

$111 a, 51 \%$

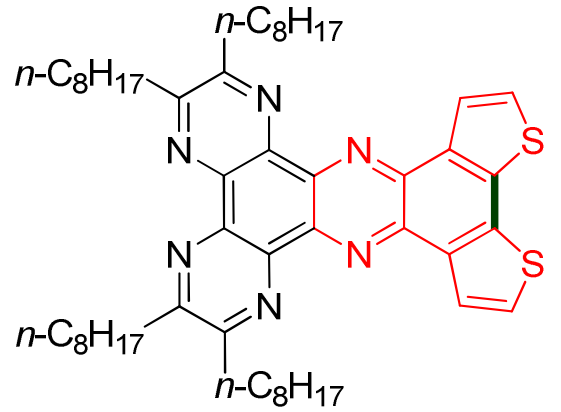

$111 b, 47 \%$

Scheme 40. Synthesis of dithieno[3,2-f:2',3'-h]quinoxalines $(\mathbf{1 1 1 a}, \mathbf{b})$ through the oxidative photocyclization of the corresponding 2,3-di(thiophen-3-yl)pyrazine derivatives (110a,b).

A common approach to the synthesis of dithieno[3,2-f:2',3'-h]quinoxalines (XXXXI) is condensation of 2,7disubstututed benzo[1,2-b:6,5- $b^{\prime}$ ]dithiophen-4,5-dione (112) with various 1,2-diaminoalryl or 1,2diamino(hetero)aryl (113), respectively, in ethanol/acetic acid or ethanol (Scheme 41). ${ }^{172,182-188}$ In particular, compounds $\mathbf{1 1 6} \mathbf{a}, \mathbf{b}$, bearing two dithieno[3,2-f:2',3'- $h$ ]quinoxaline (XXXI) skeletons, have been obtained by reacting benzo[1,2-b:6,5- $\left.b^{\prime}\right]$ dithiophen-4,5-dione $(\mathbf{1 1 4 a , b})$ with 3,6-dithienyl substituted 1,2,4,5-tetraaminobenzenes (115a,b) (Scheme 42). ${ }^{189}$ Notably, various methods for the preparation of unsubstituted and functionalized benzo[1,2- $\left.b: 6,5-b^{\prime}\right]$ dithiophene-4,5-diones (112) have been described in the literature. ${ }^{186,190-192}$ 


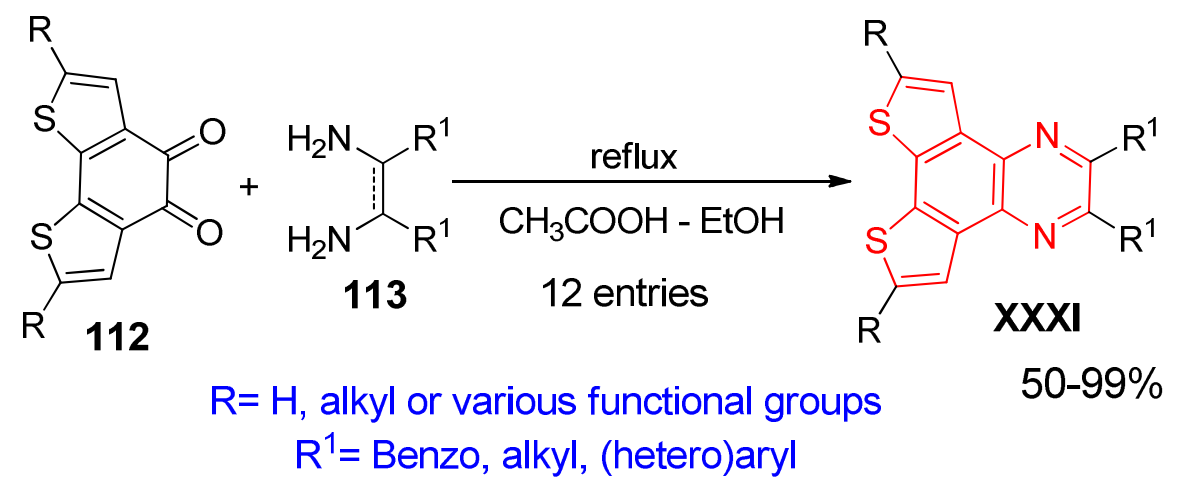

Scheme 41. Synthesis of dithieno[3,2-f:2',3'-h]quinoxalines (XXXI) by condensation of benzo[1,2-b:6,5-b']dithiophen-4,5-dione (112) with 1,2-diamine derivative (113).<smiles>[R]c1cc2c(s1)-c1sc([R])cc1C(=O)C2=O</smiles>

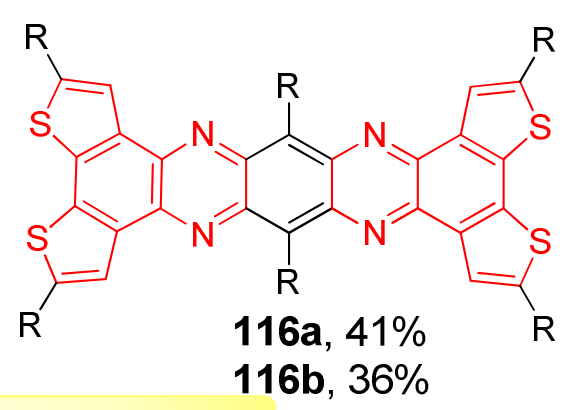

a: $R=$<smiles>Cc1ccc(C(=O)c2ccccc2)s1</smiles>

b: $R=$<smiles>[CH]=Cc1ccc(-c2ccc(CCCCCC)s2)s1</smiles>

Scheme 42. Synthesis of $2,5,8,11,14,17$-hexasubstituted dithieno[3',2':5,6;2",3":7,8]quinoxalino[2,3-i]dithieno[3,2-a:2',3'-c]phenazine derivatives (116a,b).

The skeleton of dithieno[3,2-f:2',3'-h]quinoxalines (XXXXI) can also be obtained by using condensation of benzo[1,2- $b: 6,5-b^{\prime}$ ']dithiophene-4,5-diamine (117) with alkyl or (hetero)aryl 1,2-diones (118) (Scheme

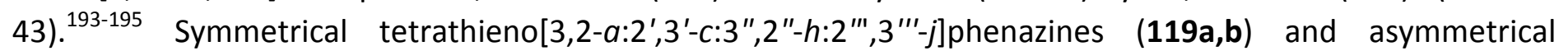

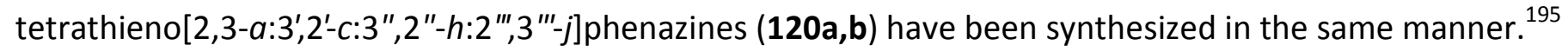


<smiles>Nc1c(N)c2ccsc2c2sccc12</smiles>
117<smiles>[R]C(=O)C([R])=O</smiles>

$\mathrm{R}=$ Alkyl, (hetero)aryl<smiles>[R]c1nc2c3ccsc3c3sccc3c2nc1[R]</smiles>

XXXI<smiles>[R]c1cc2c3nc4c5cc([R1])sc5c5sc([R1])cc5c4nc3c3cc([R])sc3c2s1</smiles>

$a: R=H ; b: R=h e x y l$<smiles>[R1]c1cc2c(s1)c1nc3c4cc([R])sc4c4sc([R])cc4c3nc1c1nc([R12])sc21</smiles>

Scheme 43. Synthesis of dithieno[3,2-f:2',3'-h]quinoxalines (XXXI) by condensation of benzo[1,2- $b: 6,5-$ $b^{\prime}$ ]dithiophen-4,5-diamine (117) with 1,2-diones (118).

Many compounds in the series of dibenzo[f,h]quinoxalines (XXVII), ${ }^{53,112,113,117,121,130}$ benzo[f]thieno [3,2-h]quinoxalines (XXVIII), ${ }^{167}$ dithieno[2,3-f:3',2'-h]quinoxalines $(\mathbf{X X X})^{173-179}$ and dithieno[3,2-f:2',3'-h]quinoxalines $(\mathbf{X X X I})^{177,178,180-184,189-192,195}$ have been found to be highly luminescent and/or prospective semiconductor materials, demonstrating their potential applications in organic electronics.

\section{Conclusions}

In this review article we have tried to present up-to-date literature data on the latest achievements in the chemistry of 1,2-, 1,3- and 1,4-diaza-analogues of triphenylene, phenanthro[9,10-b]thiophene and naphthothiophenes. In order to prepare 1,2- and 1,4-diaza derivatives of these polycyclic aromatic systems various types of condensation reactions appear to be appropriate ones, while the synthesis of 1,3-diaza compounds is usually realized via intramolecular cross-coupling reactions. It should be noted that from 32 possible diazaanalogues of triphenylene, phenanthro[9,10-b]thiophene and naphthothiophenes only 11 structures have so far been described in the literature. We believe that this review will be useful for organic chemists working in the field of polycyclic (hetero)aromatics and their metal complexes.

\section{Acknowledgements}

The research was financially supported by the Russian Science Foundation (Project No. 16-13-10435) and the Russian Foundation for Basic Research (research project №. 17-03-00011-A). 


\section{References}

1. Harvey, R.G. In Polycyclic Aromatic Hydrocarbons. New York: Wiley-VCH. 1997; p 682.

2. Boorum, M. M.; Scott, L. T. Modern Arene Chemistry. Astruc, D., Ed.; Wiley-VCH: Weinheim, 2002; pp 20-31.

https://doi.org/10.1002/3527601767.ch1

3. Berresheim, A. J.; Müller, M.; Müllen, K. Chem. Rev. 1999, 99, 1747-1786.

https://doi.org/10.1021/cr970073+

4. Watson, M. D.; Fechtenkötter, A.; Müllen, K. Chem. Rev. 2001, 101, 1267-1300.

https://doi.org/10.1021/cr990322p

5. Bendikov M, Wudl F, Perepichka DF. Chem. Rev. 2004, 104, 4891-4945.

https://doi.org/10.1021/cr030666m

6. Harvey, R. G. Curr. Org. Chem. 2004, 8, 303-323.

https://doi.org/10.2174/1385272043485918

7. Scott, L. T. Angew. Chem., Int. Ed. 2004, 43, 4994-5007.

https://doi.org/10.1002/anie.200400661

8. Anthony, J. E. Chem. Rev. 2006, 106, 5028-5048.

https://doi.org/10.1021/cr050966z

9. Sergeyev, S.; Pisula, W.; Geerts, Y H. Chem. Soc. Rev. 2007, 36, 1902-1929.

https://doi.org/10.1039/b417320c

10. Wu, J.; Pisula, W.; Müllen, K. Chem. Rev. 2007, 107, 718-747.

https://doi.org/10.1021/cr068010r

11. Murphy, A. R.; Fréchet, J. M. J. Chem. Rev. 2007, 107, 1066-1096.

https://doi.org/10.1021/cr0501386

12. Grimsdale, A. C.; Müllen, K. Macromol. Rapid Commun. 2007, 28, 1676-1702.

https://doi.org/10.1002/marc.200700247

13. Laschat, S.; Baro, A.; Steinke, N.; Giesselmann, F.; Hägele, C.; Scalia, G.; Judele, R.; Kapatsina, E.; Sauer, S.;

Schreivogel, A.; Tosoni, M. Angew. Chem., Int. Ed. 2007, 46, 4832-4887.

https://doi.org/10.1002/anie.200604203

14. Wu, J. Curr. Org. Chem. 2007,11, 1220-1240.

15. Anthony, J. E. Angew. Chem., Int. Ed. 2008, 47, 452-483.

https://doi.org/10.1002/anie.200604045

16. Feng, X.; Pisula, W.; Müllen, K. Pure Appl. Chem. 2009, 81, 2203-2224.

https://doi.org/10.1351/PAC-CON-09-07-07

17. Avlasevich, Y.; Li, C.; Müllen, K. J. Mater. Chem. 2010, 20, 3814-3826.

https://doi.org/10.1039/c000137f

18. Weil, T.; Vosch, T.; Hofkens, J.; Peneva, K.; Müllen, K. Angew. Chem., Int. Ed. 2010, 49, 9068-9093. http://dx.doi.org/10.1002/anie.200902532

19. Zhang, H.; Wu, D.; Hua Liu, S.; Yin, J. Curr. Org. Chem. 2012, 16, 2124-2158.

http://dx.doi.org/10.2174/138527212803532477

20. Pérez, D.; Guitián, E. Chem. Soc. Rev. 2004, 33, 274-283.

http://dx.doi.org/10.1039/B305549N

21. Kumar, S. Chem. Soc. Rev. 2006, 35, 83-109.

http://dx.doi.org/10.1039/B506619K 
22. Park, J. E; Kim, J. M.; Jung, J. H.; Min, S. H.; Jung, S. Y.; Baek, Y. G.; Kim, J. Y. Patent Repub. Korean Kongkae Taeho Kongbo, KR 2007102243 A , 2007.

23. Mahoney, S. J.; Ahmida, M. M.; Kayal, H.; Fox, N.; Shimizu, Y.; Eichhorn, S. H. J. Mater. Chem. 2009, 19, 9221-9232.

http://dx.doi.org/10.1039/B914290H

24. Levell, J. W.; Ruseckas, A.; Henry, J. B.; Wang, Y.; Stretton, A. D.; Mount, A. R.; Galow, T. H.; Samuel, I. D. W. J. Phys. Chem. A 2010, 114, 13291-13295.

http://dx.doi.org/10.1021/jp106622n

25. Wen, R.; Yan, C.-J.; Yan, H.-J.; Pan, G.-B.; Wan, L.-J. Chem. Commun. 2011, 47, 6915-6917. http://dx.doi.org/10.1039/C1CC11358E

26. Shimizu, M.; Nagao, I.; Tomioka, Y.; Kadowaki, T.; Hiyama, T. Tetrahedron 2011, 67, 8014-8026. http://dx.doi.org/10.1016/i.tet.2011.08.019

27. Wang, H.; Xu, X.-H.; Kojtari, A.; Ji, H.-F. J. Phys. Chem. C 2011, 115, 20091-20096. http://dx.doi.org/10.1021/jp204786f

28. Amsharov, K. Yu.; Merz, P. J. Org. Chem. 2012, 77, 5445-5448. http://dx.doi.org/10.1021/jo300783y

29. Togashi, K.; Nomura, S.; Yokoyama, N.; Yasuda, T.; Adachi, C. J. Mater. Chem. 2012, 22, 20689-20695. http://dx.doi.org/10.1039/C2JM33669C

30. Iwasaki, M.; lino, S.; Nishihara, Y. Org. Lett. 2013, 15, 5326-5329.

http://dx.doi.org/10.1021/ol4025869

31. Collins, K. D.; Honeker, R.; Vasquez-Cespedes, S.; Tang, D.-T. D.; Glorius, F. Chem. Science 2015, 6, 18161824.

http://dx.doi.org/10.1039/C4SC03051F

32. Iwasaki, M.; Araki, Y.; lino, S; Nishihara, Y. J. Org. Chem., 2015, 80, 9247-9263.

http://dx.doi.org/10.1021/acs.joc.5b01693

33. Shanmugaraju, S.; Mukherjee, P. S. Chem. Commun. 2015, 51, 16014-16032.

http://dx.doi.org/10.1039/C5CC07513K

34. Zint, S.; Ebeling, D.; Ahles, S.; Wegner, H. A.; Schirmeisen, A. J. Phys. Chem. C 2016, 120, 1615-1622. http://dx.doi.org/10.1021/acs.jpcc.5b10602

35. Zhang, R.-F.; Hu, W.-J.; Liu, Y. A.; Zhao, X.-L.; Li, J.-S.; Jiang, B.; Wen, K. J. Org. Chem. 2016, 81, $5649-5654$. http://dx.doi.org/10.1021/acs.joc.6b01115

36. Kwong, R. Patent U.S. 20160285016 A1, 2016.

37. Pan, S.; Jiang, H.; Zhang, Y.; Chen, D.; Zhang, Y. Org. Lett. 2016, 18, 5192-5195. http://dx.doi.org/10.1021/acs.orglett.6b02071

38. Iwao, M.; Lee, M. L.; Castle, R. N. J. Heterocycl. Chem. 1980, 17, 1259-1264. http://dx.doi.org/10.1002/ihet.5570170623

39. Sidorenko, T. N.; Terent'eva, G. A.; Aksenov, V. S. Khim. Geterotsikl. Soed. 1983, 2, 197-199.

40. Rademacher, P.; Heinemann, C.; Jansch, S.; Kowski, K.; Weiss, M. E. Spectrochimica Acta, Part A: Molecular and Biomolecular Spectroscopy 2000, 56A, 1179-1190.

http://dx.doi.org/10.1016/S1386-1425(99)00220-6

41. Seixas de Melo, J.; Pina, J.; Rodrigues, L. M.; Becker, R. S. J. Photochem. Photobiology, A: Chemistry 2008, 194, 67-75.

http://dx.doi.org/10.1016/j.jphotochem.2007.07.014

42. Kim, T. H.; Kim, H. S.; Son, H. S. Patent WO 2013009032 A2, 2013. 
43. Cho, D. M.; Parkin, S. R.; Watson, M. D. Org. Lett. 2005, 7, 1067-1068. http://dx.doi.org/10.1021/ol050019c

44. Park, S. J.; Bae, H. C.; Lee, I. H.; Kim, E. J.; Baek, Y. M.; Kim, Y. B.; Park, H. C.; Kim, T. H. Patent Repub. Korean Kongkae Taeho Kongbo KR 2015030794 A, 2015.

45. Xiao, S.; Zhou, H.; Stuart, A. C.; You, W. PMSE Preprints 2009, 100, 741-743.

46. Zhou, H.; Yang, L.; Price, S. C.; Knight, K. J.; You, W. Angew. Chem., Int. Ed. 2010, 49, 7992-7995. http://dx.doi.org/10.1002/anie.201003357

47. Rungtaweevoranit, B.; Butsuri, A.; Wongma, K.; Sadorn, K.; Neranon, K.; Nerungsi, C.; Thongpanchang, T. Tetrahedron Lett. 2012, 53, 1816-1818.

http://dx.doi.org/10.1016/i.tetlet.2012.01.122

48. Kageyama, T.; Uneme, S.; Takase, M.; Nomura, K.; Nishinaga, T. Australian J. Chem. 2014, 67, $722-728$. http://dx.doi.org/10.1071/CH13522

49. Löbert, M.; Mishra, A.; Uhrich, C.; Pfeiffer, M.; Bäuerle, P. J. Mater. Chem. C, 2014, 2, 4879-4892. http://dx.doi.org/10.1039/c4tc00335g

50. Desai, H. S.; Tilak, B. D. J. Sci. Ind. Res. 1961, 20B, 22-30.

51. Stępień, M.; Gońka, E.; Żyła, M.; Sprutta, N. Chem. Rev. 2017, 117, 3479-3716. http://dx.doi.org/10.1021/acs.chemrev.6b00076

52. Kwong, R.; Lam, S. T.; Lee, C. H. Patent US 20140332758 A1, 2014.

53. Thompson, M. E.; Saris, P.; Djurovich, P. I.; Chen, S. H.-F. Patent WO 2015066244 A1, 2015.

54. Altiparmakian, R. H.; Braithwaite, R. S. W. J. Chem. Soc. C 1967, 1973-1979. http://dx.doi.org/10.1039/J39670001973

55. Cort, L.A.; Mahesar, M. A. J. Chem. Soc., Perkin Trans 1 1979, 2034-2043. http://dx.doi.org/10.1039/P19790002034

56. Young, B. S.; Köhler, F.; Herges, R.; Haley, M. M. J. Org. Chem. 2011, 76, 8483-8487. http://dx.doi.org/10.1021/jo201378t

57. Chercheja, S.; Klívar, J.; Jančařík, A.; Rybáček, J.; Salzl, S.; Tarábek, J.; Pospíšil, L.; Chocholoušová, J. V.; Vacek, J.; Pohl, R.; Císařová, I.; Starý, I.; Stará, I. G. Chem. Eur. J. 2014, 20, 8477-8482. http://dx.doi.org/10.1002/chem.201402312

58. Tapolcsányi, P.; Maes, B. U. W.; Monsieurs, K.; Lemière, G. L. F.; Riedl, Z.; Hajós, G.; art Van den Driessche, B.; Dommissea, R. A.; Mátyus, P. Tetrahedron 2003, 59, 5919-5926.

http://dx.doi.org/10.1016/S0040-4020(03)00953-0

59. Tokita, S.; Hiruta, K.; Ishikawa, S.; Kitahara, K.; Nishi, H. Synthesis 1982, 10, 854-855. http://dx.doi.org/10.1055/s-1982-29973

60. Bahashwan, S. A.; Al-Harbi, N. O.; Fayed, A.; Amr, A. E.-G.; Shadid, K. A.; Alalawi, A. M.; Bassati, I. M. S. Int. J. Biol. Macromol. 2012, 51, 7-17.

http://dx.doi.org/10.1016/j.ijbiomac.2012.05.002

61. Braña, M. F.; Cacho, M.; García, M. L.; Mayoral, E. P.; López, B.; de Pascual-Teresa, B.; Ramos, A.; Acero, N.; Llinares, F.; Muñoz-Mingarro, D.; Lozach, O.; Meijer, L. J. Med. Chem. 2005, 48, 6843-6854. http://dx.doi.org/10.1021/jm058013g

62. Kashimura, N.; Sumino, F.; Nakagawa, M.; Nagahara, S. Patent Jpn. Kokai Tokkyo Koho JP 02064553 A, 1990.

63. Kim, S. I.; Sim, S. Y.; Yoo, S. J.; Lee, S. H. Patent Repub. Korean Kongkae Taeho Kongbo KR 2013142967 A, 2013.

64. Park, J. H.; Kim, S. I.; Yang, B. S. Patent Repub. Korean Kongkae Taeho Kongbo KR 2014004005 A, 2014. 
65. Shin, B. G.; Park, J. H.; Park, B. B.; Yoon, J. H.; Park, G. H.; Lee, B. H. Patent Repub. Korean Kongkae Taeho Kongbo KR 2014120089 A, 2014.

66. Shin, B. G.; Park, J. H.; Park, B. B.; Yoon, J. H.; Park, G. H.; Lee, B. H. Patent Repub. Korean Kongkae Taeho Kongbo KR 2014120090 A, 2014.

67. Yang, B. S.; Sim, S. Y.; Yoo, S. J.; Lee, S. H. Patent Repub. Korean Kongkae Taeho Kongbo KR 2014001764 A, 2014.

68. Shin, B. G.; Park, J. H.; Park, B. B.; Yoon, J. H.; Park, G. H.; Lee, B. H. Patent Repub. Korean Kongkae Taeho Kongbo KR 2014114490 A, 2014.

69. Shin, B. G.; Park, J. H.; Park, B. B.; Yoon, J. H.; Park, G. H.; Lee, B. H. Patent Repub. Korean Kongkae Taeho Kongbo KR 2014114489 A, 2014.

70. Park, J. K.; Choi, Y. H.; Park, H. K.; Cho, H. M.; Lee, D. W.; Lee, H. Y. Patent WO 2014178532 A1, 2014.

71. Sim, S. Y.; Yoo, S. J.; Lee, S. H. Patent Repub. Korean Kongkae Taeho Kongbo KR 2014141071 A, 2014.

72. Sim, S. Y.; Y., Se J.; Lee, S. H. Patent Repub. Korean Kongkae Taeho Kongbo KR 2014141970 A, 2014.

73. Park, J. H.; Park, J. G.; Jung, H. Y.; Kang, M. S.; Ha, Jong J.; Kim, W. S.; Kim, S. G.; Lee, M. J. Patent Repub. Korea KR 1555680 B1, 2015

74. Park, J. G.; Choi, Y. H.; Park, H. G.; Moon, S. Y.; Lee, D. W.; Lee, H. Y.; Cho, H. M. Patent Repub. Korean Kongkae Taeho Kongbo KR 2015122343 A, 2015.

75. Park, H. K.; Choi, Y. H.; Park, J. K.; Cho, H. M.; Lee, D. W.; Kim, S. H. Patent WO 2015083948 A1, 2015.

76. Sim, S. Y.; Yoo, S. J.; Lee, S. H. Patent Repub. Korean Kongkae Taeho Kongbo KR 2015009297 A, 2015.

77. Cho, H. M.; Lee, S. H.; Park, H. G.; Park, J. G.; Lee, D. W.; Moon, S. Y.; Hwang, S. P. Patent Repub. Korean Kongkae Taeho Kongbo KR 2015134923 A, 2015.

78. Hara, T.; Inoue, H.; Takahashi, T.; Hamada, T.; Seo, S. Patent US 20160190479 A1, 2016.

79. Yamada, Y.; Inoue, H.; Seo, H.; Takahashi, T. Patent US 20160181550 A1, 2016.

80. Jang, J. W.; Jung, H. Y.; Kim, S.-G.; Kim, W. S.; Byun, J. H.; Park, J. H.; Hwang, S. P. Patent WO 2016032150 A2, 2016.

81. Jang, J. W.; Kim, S. G.; Kim, W. S.; Kim, Y. R.; Kwon, J. T. Patent Repub. Korean Kongkae Taeho Kongbo KR 2016005944 A, 2016.

82. Hyun, S. Y.; Jung, S. U.; Kim, D. W. Patent Repub. Korean Kongkae Taeho Kongbo KR 2016041223 A, 2016.

83. Mahmoodi, N. O.; Khodaee, Z. Mendeleev Commun. 2004, 14, 304-306. http://dx.doi.org/10.1070/MC2004v014n06ABEH002014

84. Olivera, R.; Pascual, S.; Herrero, M.; SanMartin, R.; Domínguez, E. Tetrahedron Lett. 1998, 39, 7155-7158. http://dx.doi.org/10.1016/S0040-4039(98)01531-7

85. Olivera, R.; SanMartin, R.; Tellitu, I.; Domínguez, E. Tetrahedron 2002, 58, 3021-3037. http://dx.doi.org/10.1016/S0040-4020(02)00194-1

86. Kadiyala, R. R.; Tilly, D.; Nagaradja, E.; Roisnel, T.; Matulis, V. E.; Ivashkevich, O. A.; Halauko, Y. S.; Chevallier, F.; Gros, P. C.; Mongin, F. Chem. Eur. J. 2013, 19, 7944-7960.

http://dx.doi.org/10.1016/S0040-4020(02)00194-1

87. Chupakhin, O. N.; Charushin, V. N. Tetrahedron Lett. 2016, 57, 2665-2672.

https://doi.org/10.1016/i.tetlet.2016.04.084

88. Rempala, P.; Kroulik, J.; King, B. T. J. Am. Chem. Soc. 2004, 126,15002-15003.

http://dx.doi.org/10.1021/ja046513d

89. Rempala, P.; Kroulík, J.; King, B. T. J. Org. Chem. 2006, 71, 5067-5081.

http://dx.doi.org/10.1021/jo0526744

90. Olivera, R.; SanMartin, R.; Pascual, S.; Herrero, M.; Domínguez, E. Tetrahedron Lett. 1999, 40, 3479-3480. 
http://dx.doi.org/10.1016/S0040-4039(99)00428-1

91. Nagarajan, S.; Barthes, C.; Gourdon, A. Tetrahedron 2009, 65, 3767-3772.

http://dx.doi.org/10.1016/i.tet.2009.02.029

92. Draper, S. M.; Gregg, D. J.; Madathil, R. J. Am. Chem. Soc. 2002, 124, 3486-3487.

http://dx.doi.org/10.1021/ja017394u

93. Draper, S. M.; Gregg, D. J.; Schofield, E. R.; Browne, W. R.; Duati, M.; Vos, J. G.; Passaniti, P. J. Am. Chem. Soc. 2004, 126, 8694-8701.

http://dx.doi.org/10.1021/ja0491634

94. Gregg, D. J.; Bothe, E.; Höfer, P.; Passaniti, P.; Draper, S. M. Inorg. Chem. 2005, 44, 5654-5660. http://dx.doi.org/10.1021/ic050335n

95. Wijesinghe, L. P.; Lankage, B. S.; Máille, G. M. Ó.; Perera, S. D.; Nolan, D.; Wang, L.; Draper, S. M. Chem. Commun. 2014, 50, 10637-10640.

http://dx.doi.org/10.1039/c4cc03577a

96. Delaney, C.; Máille, G. M. Ó.; Twamley, B.; Draper, S. M. Org. Lett. 2016, 18, 88-91. http://dx.doi.org/10.1021/acs.orglett.5b03312

97. Mohamed, R. K.; Mondal, S.; Guerrera, J. V.; Eaton, T. M.; Albrecht-Schmitt, T. E.; Shatruk, M.; Alabugin., I. V. Angew. Chem. Int. Ed. 2016, 55, 12054-12058.

http://dx.doi.org/10.1002/anie.201606330

98. Wei, W.; Li, C.; Wang, Liu, D.; Zhang, Z. Tetrahedron 2016, 72, 5037-5046.

http://dx.doi.org/10.1016/i.tet.2016.04.080

99. Xue, P.; Du, Z.; Wang, T.; Zhang, Z. Synthesis 2015, 47, 3385-3391. http://dx.doi.org/10.1055/s-0034-1380455

100. Verbitskiy, E. V.; Rusinov, G. L.; Chupakhin, O. N.; Charushin, V. N. ARKIVOC 2016, iv, 204-216. http://dx.doi.org/ 10.3998/ark.5550190.p009.623

101. Verbitskiy, E. V.; Cheprakova, E. M.; Makarova, N. I.; Dorogan, I V.; Metelitsa, A. V.; Minkin, V. I.; Slepukhin, P. A.; Svalova, T. S.; Ivanova, A. V.; Kozitsina, A. N.; Rusinov, G. L.; Chupakhin, O. N.; Charushin, V. N. Eur. J. Org. Chem. 2016, 1420-1428.

http://dx.doi.org/10.1002/ejoc.201501450

102. Verbitskiy, E. V.; Slepukhin, P. A.; Valova, M. A.; Cheprakova, E. M.; Schepochkin, A. V.; Rusinov, G. L.; Charushin, V. N. Eur. J. Org. Chem. 2014, 8133-8141.

http://dx.doi.org/10.1002/ejoc.201403212

103. Martynoff, M. Bull. Soc. Chim. France 1951, 214-20.

104. Boyer, J. H.; Buriks, R.S.; Toggweiler, U. J. Am. Chem. Soc. 1960, 82, 2213-2215. http://dx.doi.org/10.1021/ja01494a030

105. Banerji, K. D.; Mazumdar, A. K. D.; Saha, N. K.; Guha, S. K. J. Indian Chem. Soc. 1980, 57, 86-88.

106. Minsky, A.; Cohen, Y.; Rabinovitz, M. J. Am. Chem. Soc. 1985, 107, 1501-1505. http://dx.doi.org/10.1021/ja00292a009

107. Grivas, S.; Tian, W. Acta Chem. Scand. 1992, 46, 1109-1113. http://dx.doi.org/10.3891/acta.chem.scand.46-1109

108. Demirayak, S.; Benkli, K.; Mohsen, U. A.; Guven, K. Acta Pharm. Turcica 1998, 40, 193-196.

109. Abramov, I. G.; Smirnov, A. V.; Abramova, M. B.; Begunov, R. S.; Kalandadze, L. S.; Smirnova, O. V.; Plakhtinskii, V. V. Izvestiya Vysshikh Uchebnykh Zavedenii, Khimiya i Khimicheskaya Tekhnologiya 2001, 44, 134-139. 
110. Edelmann, E.M.; Raimundo, J.-P.; Utesch, N. F.; Diederich, F. Helvetica Chimica Acta 2002, 85, 21952213.

http://dx.doi.org/10.1002/1522-2675(200207)85:7<2195::AID-HLCA2195>3.0.CO;2-G

111. Balakirev, A. E.; Maizlish, V. E.; Shaposhnikov, G. P. Russ. J. General Chem. 2002, 72, 311-314. http://dx.doi.org/10.1023/A:1015406625722

112. Nishida, J.; Murai, S.; Fujiwara, E.; Tada, H.; Tomura, M.; Yamashita, Y. Org. Lett. 2004, 6, 2007-2010. http://dx.doi.org/10.1021/ol0494010

113. Lecloux, D. D.; Guidry, M. A.; Herron, N.; Radu, N. S.; Smith, E. M.; Wang, Y. Patent WO 2004006355 A2, 2004.

114. Akar, D.; İncesu, Z.; Gündoğdu-Karaburun, N.; Benkli, K.; Işikdağ, İ. Turkish J. Pharm. Sci. 2004, 1, 193202.

115. Ding, Y.; Girardet, J.-L.; Smith, K. L.; Larson, G.; Prigaro, B.; Lai, V. C. H.; Zhong, W.; Wu, J. Z. Bioorg. Med. Chem. Lett. 2005, 15, 675-678.

http://dx.doi.org/10.1016/j.bmcl.2004.11.028

116. Kumamoto, K.; lida, H.; Hamana, H.; Kotsuki, H.; Matsumoto, K. Heterocycles 2005, 66, 675-681. http://dx.doi.org/10.3987/COM-05-S(K)69

117. Gautrot, J. E.; Hodge, P. Polymer 2007, 48, 7065-7077. http://dx.doi.org/10.1016/i.polymer.2007.09.045

118. Sherif, M. H.; Assy, M. G.; Zahran, F.; Khalil, A. Afinidad 2008, 65, 156-162.

119. Niknam, K.; Zolfigol, M. A.; Tavakolic, Z.; Heydari, Z. J. Chin. Chem. Soc. 2008, 55, 1373-1378. http://dx.doi.org/10.1002/jccs.200800206

120. Niknam, K.; Saberi, D.; Mohagheghnejad, M. Molecules 2009, 14, 1915-1926. http://dx.doi.org/10.3390/molecules14051915

121. Dubey, R. K.; Kumpulainen, T.; Efimov, A.; Tkachenko, N. V.; Lemmetyinen, H. Eur. J. Org. Chem. 2010, 3428-3436.

http://dx.doi.org/10.1002/ejoc.201000136

122. Abdolkarim, Z.; Alireza, H.; Abolfath, P.; Reza, M.-Z. A.; Fatemeh, K.; Zahra, P.; Maasoomeh, A.-S.; Maasoomeh, K.; Mehrnoosh, R.; Hanafieh, D. J. Serb. Chem. Soc. 2010, 75, 1315-1324.

http://dx.doi.org/10.2298/JSC091014109Z

123. Sharma, R. K.; Sharma, C. Catalysis Commun. 2011, 12, 327-331.

http://dx.doi.org/10.1016/j.catcom.2010.10.011

124. Rashedian, F.; Saberib, D.; Niknam, K. J. Chin. Chem. Soc. 2010, 57, 998-1006. http://dx.doi.org/10.1002/iccs.201000139

125. Chavan, H. V.; Adsul, L. K.; Bandgar, B. P. J. Chem. Sci. 2011, 123, 477-483.

126. Karami, B.; Khodabakhshi, S.; Nikrooz, M. Polycyclic Aromatic Compounds 2011, 31, 97-109. http://dx.doi.org/10.1080/10406638.2011.572577

127. Bachhav, H. M.; Bhagat, S. B.; Telvekar, V. N. Tetrahedron Lett. 2011, 52, 5697- 5701. http://dx.doi.org/10.1016/i.tetlet.2011.08.105

128. Karami, B.; Khodabakhshi, S. J. Serb. Chem. Soc. 2011, 76, 1191-1198. http://dx.doi.org/10.2298/JSC100801104K

129. Heshmatollah, A.; Mahmood, T.; Fatemeh, S.; Pourya, B. Bull. Korean Chem. Soc. 2011, 32, 3720-3725. http://dx.doi.org/10.5012/bkcs.2011.32.10.3720

130. Guo, W.; Engelman, B. J.; Haywood, T. L.; Blok, N. B.; Beaudoin, D. S.; Obare, S. O. Talanta 2011, 87, 276283. 
http://dx.doi.org/10.1016/i.talanta.2011.10.015

131. Carlier L.; Baron, M.; Chamayou, A.; Couarraze, G. Tetrahedron Lett. 2011, 52, 4686-4689. http://dx.doi.org/10.1016/i.tetlet.2011.07.003

132. Kumbhar, A.; Kamble, S.; Barge, M.; Rashinkar, G.; Salunkhe, R. Tetrahedron Lett. 2012, 53, $2756-2760$. http://dx.doi.org/10.1016/j.tetlet.2012.03.097

133. Hasaninejad, A.; Shekouhy, M.; Zare, A. Catal. Sci. Technol. 2012, 2, 201-214. http://dx.doi.org/10.1039/C1CY00332A

134. Karami, B.; Khodabakhshi, S.; Nikrooz, M. J. Chin. Chem. Soc. 2012, 59, 187-192. http://dx.doi.org/10.1002/iccs.201100421

135. Karami, B.; Rooydel, R.; Khodabakhshi, S. Acta Chim. Slov. 2012, 59, 183-188.

136. Khodabakhshi, S.; Karami, B. Catal. Sci. Technol. 2012, 2, 1940-1944. http://dx.doi.org/10.1039/C2CY20227A

137. Soleymani, R.; Niakan, N.; Tayeb, S.; Hakimi, S. Oriental J. Chem. 2012, 28, 687-701. https://doi.org/10.13005/ojc/280208

138. Habibzadeh, S. Org. Chem. Ind. J. 2012, 8, 473-476.

139. Sajjadifar, S.; Zolfigol, M. A.; Mirshokraie, S. A.; Miri, S.; Louie, O.; Nezhad, E. R.; Karimian, S.; Darvishi, G.; Donyadari, E.; Farahmand, S. Amer. J. Org. Chem. 2012, 2, 97-104.

http://dx.doi.org/10.5923/i.ajoc.20120204.04

140. Kadam, H. K.; Khan, S.; Kunkalkar, R. A.; Tilve, S. G. Tetrahedron Lett. 2013, 54, 1003-1007. http://dx.doi.org/10.1016/i.tetlet.2012.12.041

141. Shirini, F., Akbari-Dadamahaleh, S.; Mohammad-Khah, A.; Aliakbar, A.-R. Comptes Rend. Chimie 2013, 16, 207-216. http://dx.doi.org/10.1016/j.crci.2012.12.004

142. Malakooti, R.; Bardajee, G. R.; Mahmoudi, H.; Kakavand, N. Catal. Lett. 2013, 143, 853-861. http://dx.doi.org/10.1007/s10562-013-0999-1

143. Jafarpour, M.; Rezaeifard, A.; Ghahramaninezhad, M.; Tabibi, T. New J. Chem. 2013, 37, 2087-2095. http://dx.doi.org/10.1039/C3NJ00058C

144. Mulik, A.; Chandam, D.; Patil, P.; Patil, D.; Jagdale, S.; Deshmukh, M. J. Molecular Liquids 2013, 179, 104109. http://dx.doi.org/10.1016/i.molliq.2012.12.006

145. Bardajee, G. R.; Mizani, F.; Rostami, I.; Mohamadi, A. Polycyclic Aromatic Compounds 2013, 33, 419-429. http://dx.doi.org/10.1080/10406638.2013.791995

146. Karami, B.; Khodabakhshi, S. J. Chil. Chem. Soc. 2013, 58, 1655-1658. http://dx.doi.org/10.4067/S0717-97072013000200002

147. Sadeghi, B.; Karimi, F. Iranian J. Catalysis 2013, 3, 1-7.

148. Nezhad, E. R.; Sajjadifar, S.; Miri, S.; Karimian, S.; Abbasi, Z. Iranian J. Catalysis 2013, 3, 191-196.

149. Kolvari, E.; Zolfigol, M. A.; Koukabi, N.; Gilandust, M.; Kordi, A.-V. J. Iran. Chem. Soc. 2013, 10, $1183-1191$. http://dx.doi.org/10.1007/s13738-013-0252-2

150. Jafarpour, M.; Rezapour, E.; Ghahramaninezhad, M.; Rezaeifard, A. New J. Chem. 2014, 38, 676-682. http://dx.doi.org/10.1039/C3NJ00655G

151. Sajjadifar, S.; Nezhad, E. R., Khosravani, E. Chem. Science Trans. 2014, 3, 292-302. http://dx.doi.org/10.7598/cst2014.506

152. Samanta, S.; Gupta, A. D.; Mallik, A. K. Monatsh. Chem. 2014, 145, 1669-1673. http://dx.doi.org/10.1007/s00706-014-1242-5 
153. Bandyopadhyay, D.; Zavala, D.; Banik, B. K. Current Organocatalysis 2014, 1, 59-65. http://dx.doi.org/10.2174/22133372114016660001

154. Tajbakhsh, M.; Bazzar, M.; Ramzanian, S. F.; Tajbakhsh, M. Applied Clay Science 2014, 88-89, 178-185. http://dx.doi.org/10.1016/i.clay.2013.12.023

155. Sajjadifar, S.; Miri, S. Int. J. ChemTech Res. 2014, 6, 5433-5440.

156. Baghbanian, S. M. Chinese Chem. Lett. 2015, 26, 1113-1116. http://dx.doi.org/10.1016/i.cclet.2015.04.037

157. Mulik, A. G.; Chandam, D. R.; Patil, D. R.; Patil, P. P.; Mulik, G. N.; Salunkhe, S. T.; Deshmukh, M. B. Res. Chem. Intermed. 2015, 41, 10085-10096.

http://dx.doi.org/10.1007/s11164-015-2014-5

158. Shamsi-Sani, M.; Shirini, F.; Abedini, M.; Seddighi, M. Res. Chem. Intermed. 2016, 42, 1091-1099. http://dx.doi.org/10.1007/s11164-015-2075-5

159. Jafarpour, M.; Rezaeifard, A. Transition Met. Chem. 2016, 41, 205-211. http://dx.doi.org/10.1007/s11243-015-0012-5

160. Zhang, C.; Zhang, Y.; Liu, Q.; Gao, R. Yingyong Huagong 2008, 37, 430-433.

161. Amer, A. M.; El-Farargy, A. F.; Yousif, N. M.; Fayed, A. A. Chem. Heterocycl. Compds. 2011, 47, $101-107$. http://dx.doi.org/10.1007/s10593-011-0726-z

162. Khodaee, Z.; Yahyazadeh, A.; Mahmoodi, N. O.; Zanjanchi, M. A.; Azimi, V. J. Mol. Struct. 2012, 1029, $92-$ 97.

http://dx.doi.org/10.1016/i.molstruc.2012.06.021

163. Kijak, M.; Peukert, S.; Mengesha, E.; Sepioł, J.; Gil, M. J. Phys. Chem. A 2016, 120, 7817-7827. http://dx.doi.org/10.1021/acs.jpca.6b06475

164. Tamarkin, D.; Cohen, Y.; Rabinovitz, M. Synthesis 1987, 2, 196-197. http://dx.doi.org/10.1055/s-1987-27889

165. Rabinovitz, M.; Tamarkin, D. Synthetic Metals 1988, 23, 487-491. http://dx.doi.org/10.1016/0379-6779(88)90526-7

166. Tamarkin, D.; Rabinovitz, M. J.Org. Chem. 1987, 52, 3472-3474. http://dx.doi.org/10.1021/jo00391a065

167. Yoshida, K.; Hayashi, A.; Mamura, T. Patent JP 2008195749 A, 2008.

168. Kruber, O.; Raeithel, A. Chemische Berichte 1953, 86, 366-371. http://dx.doi.org/10.1002/cber.19530860309

169. Badger, G. M.; Christie, B. J. J. Chem. Soc. 1956, 3435-3437. http://dx.doi.org/10.1039/JR9560003435

170. Marie, C.; Buu-Hoï, N. P.; Jacquignon, P. J. Chem. Soc. C 1971, 431-434.

http://dx.doi.org/10.1039/J39710000431

171. Kurokawa, S. Bull. Chem. Soc. Jpn 1970, 43, 1454-1459.

172. Meyer, A.; Sigmund, E.; Luppertz, F.; Schnakenburg, G.; Gadaczek, I.; Bredow, T.; Jester, S.-S.; Höger, S. Beilstein J. Org. Chem. 2010, 6, 1180-1187.

http://dx.doi.org/10.3762/bjoc.6.135

173. Guo, Z.-H.; Lei, T.; Jin, Z.-X.; Wang, J.-Y.; Pei, J. Org. Lett. 2013, 15, 3530-3533. http://dx.doi.org/10.1021/ol4012025

174. Chaudhuri, D.; Sigmund, E.; Meyer, A.; Röck, L; Klemm, P.; Lautenschlager, S.; Schmid, A.; Yost, S. R.; Van Voorhis, T.; Bange, S.; Höger, S.; Lupton, J. M. Angew. Chem. Int. Ed. 2013, 52, 13449-13452. http://dx.doi.org/10.1002/anie.201307601 
175. Putta, A.; Mottishaw, J. D.; Wang, Z.; Sun, H. Cryst. Growth Des. 2014, 14, 350-356. http://dx.doi.org/10.1021/cg401637a

176. Chen, Y.; Lu, X.; Xiang, C.; Ling, Y.; Zhou, G. Chem. Asian J. 2016, 11, 874-881. http://dx.doi.org/10.1002/asia.201501389

177. Xie, Y.; Fujimoto, T.; Dalgleish, S.; Shuku, Y.; Matsushita, M. M.; Awaga, K. J. Mater. Chem. C 2013, 1, 3467-3481. http://dx.doi.org/10.1039/c3tc30346b

178. Zhang, J.; Cai, W.; Huang, H.; Wang, E.; Zhong, C.; Liu, S.; Wang, M.; Duan, C.; Yang, T.; Cao, Y. Macromolecules 2011, 44, 894-901.

http://dx.doi.org/10.1021/ma1027164

179. Keshtov, M. L.; Kuklin, S. A.; Chen, F. C.; Khokhlov, A. R.; Kurchania, R.; Sharma, G. D. J. Polym. Sci., Part A: Polym. Chem. 2015, 53, 2390-2398.

http://dx.doi.org/10.1002/pola.27699

180. Black, H. T.; Liu, S.; Ashby, V. S. Org. Lett. 2011, 13, 6492-6495. http://dx.doi.org/10.1021/ol202662s

181. Qian, C.; Zhao, W.-H.; Tian, Y.; Jiang, G.-F.; Zhan, T.-G.; Zhao, X. Chem. Asian J. 2016, 11, 839-843. http://dx.doi.org/10.1002/asia.201600018

182. Xiao, S.; Zhou, H.; You, W. Macromolecules 2008, 41, 5688-5696. http://dx.doi.org/10.1021/ma800776q

183. Guégano, X.; Kanibolotsky, A. L.; Blum, C.; Mertens, S. F. L.; Liu, S.-X.; Neels, A.; Hagemann, H.; Skabara, P. J.; Leutwyler, S.; Wandlowski, T.; Hauser, A.; Decurtins, S. Chem. Eur. J. 2009, 15, 63-66.

http://dx.doi.org/10.1002/chem.200802011

184. Kirner, H. J.; Chebotareva, N.; Aebischer, O. F. Patent WO 2010136401 A2, 2010.

185. Zhang, Y.; Zou, J.; Yip, H.-L.; Chen, K.-S.; Davies, J. A.; Sun, Y.; Jen, A., K.-Y. Macromolecules 2011, 44, 4752-4758.

http://dx.doi.org/10.1021/ma2008699

186. Chen, W.; Tan, S. Y.; Zhao, Y.; Zhang, Q. Org. Chem. Front. 2014, 1, 391-394. http://dx.doi.org/10.1039/C4Q000032C

187. Aboubakr, H.; Brisset, H.; Siriand, O.; Raimundo, J.-M. Anal. Chem. 2013, 85, 9968-9974. http://dx.doi.org/10.1021/ac4027934

188. Bhuwalka, A.; Mike, J. F.; Intemann, J. J.; Ellern, A.; Jeffries-EL, M. Org. Biomol. Chem. 2015, 13, 94629470.

http://dx.doi.org/10.1039/C5OB01135C

189. Zhang, Y.; Shi, J.; He, X.; Tu, G. J. Mater. Chem. A 2016, 4, 13519-13524.

http://dx.doi.org/10.1039/C6TA03784D

190. Getmanenko, Y. A.; Marder, S. R.; Hwang, D. K.; Kippelen, B. Patent WO 2013023107 A1, 2013.

191. Getmanenko, Y. A.; Marder, S. R.; Hwang, D. K.; Kippelen, B. Patent WO 2013023108 A1, 2013.

192. Getmanenko, Y. A.; Fonari, M.; Risko, C.; Sandhu, B.; Galán, E.; Zhu, L.; Tongwa, P.; Hwang, D. K.; Singh, S.; Wang, H.; Tiwari, S. P.; Loo, Y.-L.; Brédas, J.-L.; Kippelen, B.; Tatiana T.; Marder, S. R. J. Mater. Chem. C 2013, 1, 1467-1481. http://dx.doi.org/10.1039/C2TC00805J

193. Ni, J.-S.; Kao, W.-S.; Chou, H.-J.; Lin, J. T. ChemSusChem 2015, 8, 2932-2939. http://dx.doi.org/10.1002/cssc.201500193 
194. Huang, Z.-S.; Zang, X.-F.; Hua, T.; Wang, L.; Meier, H.; Cao, D. ACS Appl. Mater. Interfaces 2015, 7, 2041820429.

http://dx.doi.org/10.1021/acsami.5b06404

195. Arroyave, F. A.; Richard, C. A.; Reynolds, J. R. Org. Lett. 2012, 14, 6138-6141.

http://dx.doi.org/10.1021/ol302704v

\section{Authors' Biographies}

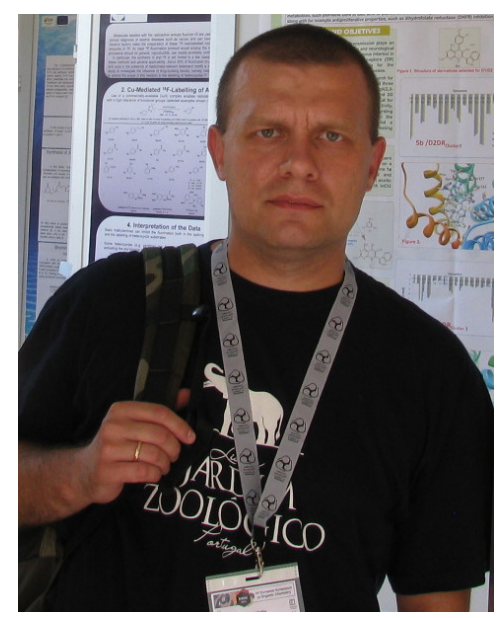

Egor V. Verbitskiy was born in Sverdlovsk (at the present time Ekaterinburg), USSR, in 1981. He received his B.Sc. in Chemistry in 2003 and M.Sc. in 2005 with Organic Chemistry specialization from Ural State University (USU). In 2008, he obtained his Ph.D. at the Institute of Organic Synthesis of Ural Branch of RAS under the supervision of Professor Valery N. Charushin. He is currently a senior researcher at the Institute of Organic Synthesis of Ural Branch of RAS. His current research interests include novel methods in organic synthesis, heterocyclic chemistry, photochemistry, new analytical methods, chemosensors and medicinal chemistry

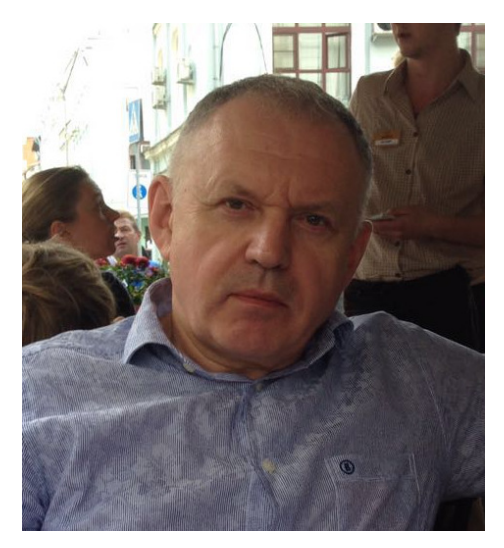

Gennady L. Rusinov was born in Beelitz, Germany, in 1954. He graduated the Ural Polytechnical Institute (UPI) in 1976. He obtained his Ph.D. in 1980 from the same institute under the supervision of Professor Isaak Postovsky. After that he joined the Institute of Organic Synthesis of Ural Branch of RAS. He is currently a leading researcher in Laboratory of Heterocyclic compounds at the Institute of Organic Synthesis of Ural Branch of RAS. His current research interests include novel methods in organic synthesis, heterocyclic 
chemistry, fluorine chemistry, green chemistry, coordination chemistry, photochemistry, new analytical methods, chemosensors, molecular recognition, and supramolecular chemistry; medicinal chemistry.

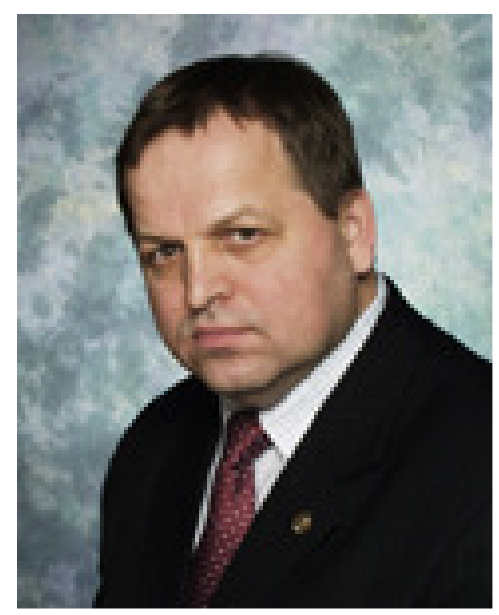

Valery N. Charushin is an Academician of RAS, Professor and Head of the Department of Organic and Biomolecular Chemistry at Ural Federal University, Director of the Institute of Organic Synthesis of Ural Branch of RAS. Prof. Charushin graduated with Honors from the Ural Polytechnical Institute (UPI) in 1973. In 1976, he earned his PhD in Organic Chemistry. In 1981-1982, he joined the research group of Prof. Henk van der Plas (Wageningen University, Wageningen, the Netherlands) where he worked on ring transformations of azaaromatics. In 1987, he earned the Doctor of Science Degree in Organic Chemistry. His current research interests include novel methods in organic synthesis, heterocyclic chemistry, fluorine chemistry, green chemistry, coordination chemistry, photochemistry, new analytical methods, chemosensors, molecular recognition, and supramolecular chemistry; medicinal chemistry. 